\title{
COMUNICAÇÃO NAS RELAÇÕES DE TRABALHO: ANÁLISE CRÍTICA DE VOZES DA COMUNICAÇÃO ORGANIZACIONAL NO BRASIL
}




\section{COMUNICAÇÃO NAS RELAÇÕES DE TRABALHO: ANÁLISE CRÍTICA DE VOZES DA COMUNICAÇÃO ORGANIZACIONAL NO BRASIL}

Dissertação apresentada ao Programa de PósGraduação em Ciências da Comunicação, área de concentração em Interfaces Sociais da Comunicação, linha de pesquisa Políticas e Estratégias de Comunicação, da Escola de Comunicações e Artes da Universidade de São Paulo, como exigência parcial para obtenção do Título de Mestre em Ciências da Comunicação, sob a orientação da Profa. Dra. Margarida Maria Krohling Kunsch.

São Paulo 
Rebechi, Claudia Nociolini

Comunicação nas relações de trabalho: análise crítica de vozes da

comunicação organizacional no Brasil / Claudia Nociolini Rebechi. - São Paulo: Universidade de São Paulo / Escola de Comunicações e Artes, 2009. $x, 145$ f.; $31 \mathrm{~cm}$.

Orientadora: Margarida Maria Krohling Kunsch

Dissertação (mestrado) - USP / Escola de Comunicações e Artes / Programa de Pós-Graduação em Ciências da Comunicação, 2009.

Referências bibliográficas: f. 130-140

1. Comunicação. 2. Trabalho. 3. Comunicação Organizacional. 4. Associação Brasileira de Comunicação Empresarial (ABERJE). 5. Comunicação Interna. 6. Interfaces Sociais da Comunicação - Tese. I. Kunsch, Margarida Maria Krohling. II. Universidade de São Paulo, Escola de Comunicações e Artes, Programa de Pós-Graduação em Ciências da Comunicação III. Título. 
Membros da Comissão Julgadora 
Ao meu insubstituível companheiro, Arlindo, por compartilhar comigo sua profunda humanidade, fazendo de nossa convivência uma paixão.

À família Nociolini, pais e irmão, por todos esses anos de dedicação e ternura; suporte e confiança em minhas escolhas.

À família Rebechi, por seu carinho e apoio desde o primeiro momento que entrei em suas vidas. 


\section{Agradecimentos}

Certamente, o desenvolvimento desta dissertação é fruto da contribuição direta e indireta de diversas pessoas. A elas devo oferecer minha gratidão.

Em primeiro lugar, à Profa. Dra. Margarida M. K. Kunsch, orientadora compreensiva que soube respeitar minhas escolhas neste estudo e grande incentivadora e apoiadora nos meus primeiros passos na carreira acadêmica.

Ao meu marido Arlindo Rebechi Jr. pelo companheirismo e dedicação.

Ainda, agradeço aos professores e pesquisadores que de alguma maneira, seja na sala de aula ou por meio de suas obras, guiaram-me neste estudo; em especial, à Profa. Dra. Roseli Fígaro e à Profa. Dra. Liana Gottlieb que participaram do meu exame de qualificação.

Outra pessoa que eu não poderia deixar de citar aqui se refere ao Prof. Dr. Paulo Nassar que, em nome da ABERJE, possibilitou minhas visitas ao Centro de Memória e Referência desta associação, bem como minha participação em alguns dos eventos produzidos por ela. Meus agradecimentos se estendem à própria associação e seus funcionários.

O meu obrigado, também, a todos os funcionários técnicos e administrativos da Universidade de São Paulo que dedicam seu tempo e conhecimento para o desenvolvimento desta instituição.

Aos meus colegas - professores, funcionários e alunos - da Universidade Metodista de São Paulo que sempre me agraciaram com palavras e gestos de incentivo ao longo do percurso deste estudo que aqui se apresenta.

Por último, mas não em menor importância, destaco meus familiares e amigos, companheiros dos momentos difíceis e protagonistas das ocasiões alegres da minha vida. 
Na Idade da Máquina, a mão teria, por acaso, perdido as finíssimas articulações com que se casava às saliências e reentrâncias da matéria? O artesanato, por força, recua ou decai, e as mãos manobram nas linhas de montagem à distância dos seus produtos. Pressionam botôes, acionam manivelas, ligam e desligam chaves, puxam e empurram alavancas, controlam painéis, cedendo à máquina tarefas que outrora lhes cabiam. A máquina, dócil e por isso violenta, cumpre exata o que the mandam fazer; mas, se poupa o músculo do operário, também sabe cobrar exigindo que vele junto a ela sem cessar: se não, decepa dedos distraídos.

Alfredo Bosi, em O ser e o tempo da poesia. 


\section{Resumo}

REBECHI, Claudia Nociolini. Comunicação nas relações de trabalho: análise crítica de vozes da comunicação organizacional no Brasil. 2009. 145 f. Dissertação (Mestrado em Ciências da Comunicação) - Escola de Comunicações e Artes, Universidade de São Paulo, São Paulo, 2009.

Esta dissertação busca uma reflexão crítica sobre a comunicação nas relações de trabalho no contexto da comunicação organizacional no Brasil. A partir de investigações preliminares sobre esta área de conhecimento, notamos que suas discussões a respeito desta temática apresentavam poucas análises críticas apoiadas nos aspectos que tem configurado as transformações contemporâneas no mundo do trabalho. Este cenário despertou nosso interesse em compreender como determinados estudiosos, bem como a Associação Brasileira de Comunicação Empresarial (ABERJE), ambos considerados vozes representativas da área, concebem as relações entre organizações e trabalhadores por meio da comunicação. Com base neste objetivo principal, desenvolvemos esta dissertação, em suma, seguindo duas etapas de nosso percurso metodológico. A primeira refere-se às análises de certas vozes autorais significativas para a área da comunicação organizacional. Já a segunda contempla análises da revista Comunicação Empresarial publicada pela associação. As análises neste periódico foram balizadas, em grande parte, pelos estudos do campo da sociologia do trabalho, cujas discussões nos possibilitaram entender as distintas modificações concernentes ao mundo do trabalho. Finalmente, constatamos, em especial, que a área da comunicação organizacional, a partir do seu pensamento hegemônico calcado na gestão estratégica, apresenta interesses orientados a planejar estratégias de comunicação que possam auxiliar as tentativas de organizações em mobilizar a subjetividade do trabalhador, buscando incorporá-lo à própria racionalidade das organizações.

Palavras-chave: Comunicação; Trabalho; Comunicação Organizacional; Associação Brasileira de Comunicação Empresarial (ABERJE); Comunicação Interna. 


\section{Abstract}

REBECHI, Claudia Nociolini. Communication in working relationships critical analysis of organizational communication voices in Brazil. 2009. 145 f. Dissertation (Master of Science in Communication) - School of Communication and Arts, University of São Paulo, São Paulo, 2009.

This dissertation seeks a critical reflection on the communication in working relationships in the context of organizational communication in Brazil. Beginning with the preliminary investigations on this field of knowledge, we noticed that discussions about this subject have not expressed enough analyses supported by aspects that form contemporary transformations in the world of work. This scenario proposes an understanding: how certain scholars, and the Brazilian Association for Business Communication (ABERJE), both considered representative voices from this field, comprehend the relationships between organizations and workers through communication. From this main objective, we developed this dissertation, in short, in two steps. First, we analysed important voices of scholars from field of organizational communication. Second, we analysed the magazine published by ABERJE. This analysis of the magazine have been supported by studies of sociology of work; it help us to understand changes about the world of work. Finally, we verified that the field of organizational communication, from its hegemonic thinking based on strategic management, tries to plan communication strategies that can help organizations in their attempts to mobilize the subjectivity of the worker to rationality of organizations.

Keywords: Communication; Work; Organizational Communication; Brazilian Association for Business Communication (ABERJE); Internal Communication. 


\section{Sumário}

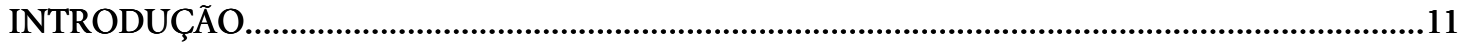

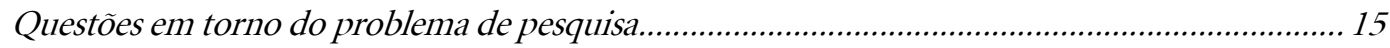

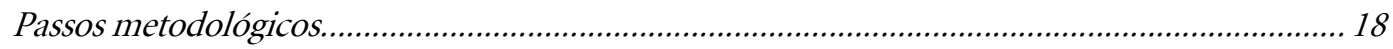

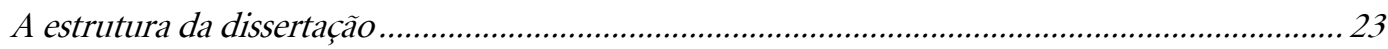

I. COMUNICAÇÃO ORGANIZACIONAL: ASPECTOS DA TRAJETORIA BRASILEIRA.................25

1.1. MOMENTOS DECISIVOS DA FORMAÇÃO DO CAMPO DA COMUNICAÇÃO ORGANIZACIONAL NO

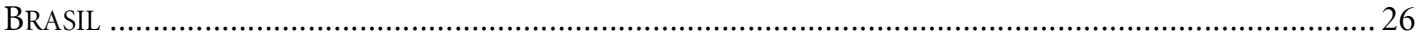

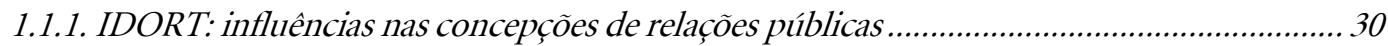

1.2. O DISCURSO HEGEMONICO DA COMUNICAÇÃO ORGANIZACIONAL ................................................... 35

1.3. AS TEORIAS DA COMUNICAÇÃO NA FORMAÇÃO DO CAMPO DA COMUNICAÇÃO ORGANIZACIONAL

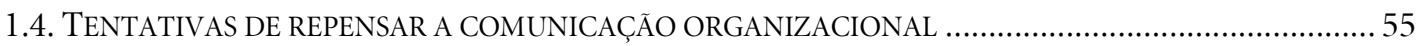

II. “COMUNICAÇÃO INTERNA”: CAMINHOS ESCOLHIDOS POR VOZES AUTORAIS ............61

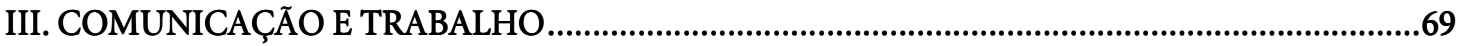

3.1. O TRABALHO COMO NORTEADOR DAS RELAÇÕES SOCIAIS ............................................................... 71

3.2. A ORGANIZAÇÃO E A GESTÃO DA PRODUÇÃO NA REALIZAÇÃO DO TRABALHO ………………….... 74

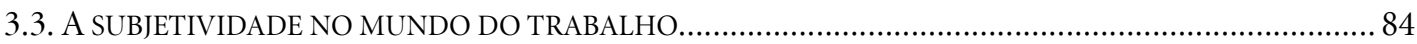

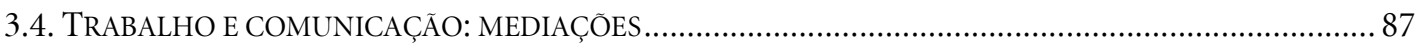

IV. ABERJE: AS PRÁTICAS DE COMUNICAÇÃO INTERNA E AS RESSONÂNCIAS NA COMUNICAÇÃO ORGANIZACIONAL........................................................................................91

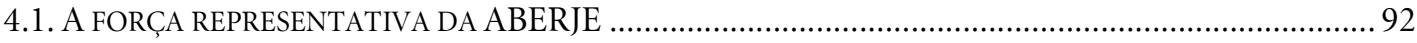

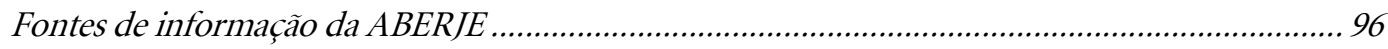

Coleção "Comunicação interna: a força das empresas".............................................................97

4.2. ESTUDO DA COMUNICAÇÃO INTERNA NA REVISTA COMUNICAÇÃO EMPRESARIAL PUBLICADA PELA

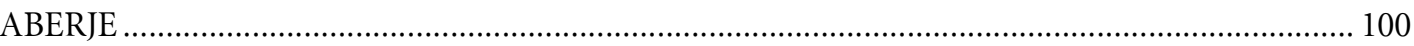

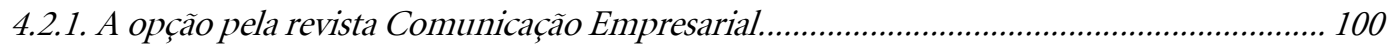

4.2.2. Análise da revista Comunicação Empresarial................................................................. 101

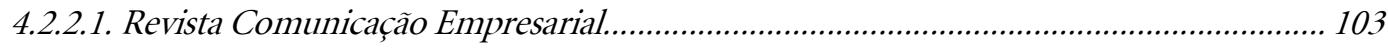

Incorporação do trabalhador à racionalidade da organização ................................................... 103

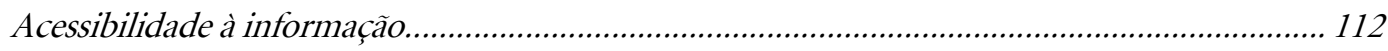

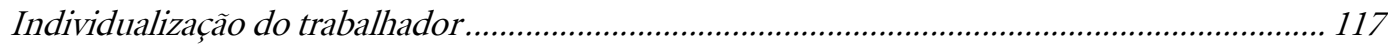

Valorização do trabalhador como pessoa......................................................................... 120

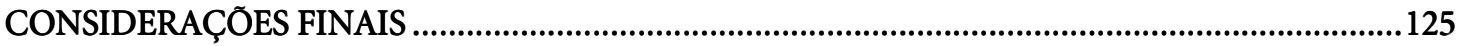

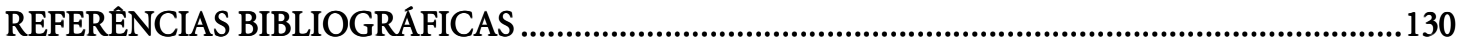

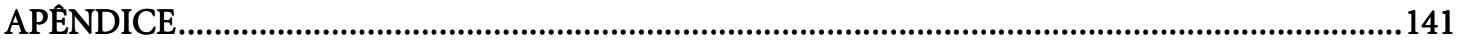

QUADRO DESCRITIVO DOS TEXTOS ANALISADOS DO PERIÓDICO REVISTA BRASILEIRA DE COMUNICAÇÃO EMPRESARIAL [COMUNICAÇÃO EMPRESARIAL], EDITADO PELA ABERJE. 


\section{Introdução}

O fator trabalho tem se apresentado como um tema de grande interesse nos debates da opinião pública e da sociedade. Seja na imprensa, nas universidades, no meio empresarial, nos espaços públicos de natureza diversa, as questões sobre o trabalho aparecem constantemente nas discussões de interesse geral. Interpretado, à primeira vista, como sinônimo de atividade econômica ou forma de sustento, o fator trabalho tem sido um elemento central na vida das pessoas. Em momentos de crise econômica, como esta vivenciada na atualidade, as questões referentes ao trabalho parecem ganhar maior visibilidade nas pautas dos debates públicos.

Os interesses de grupos e classe sociais emergem fortemente neste tipo de situação, configurando uma disputa, nem sempre tão explícita, pela exploração do trabalho. Exemplo disso são as discussões que a imprensa tem mediado sobre possíveis mudanças na legislação trabalhista. Temas como a Consolidação das Leis de Trabalho (CLT), bem como os projetos de lei na área trabalhista que sugerem a redução da jornada de trabalho sem a alteração de salário, a extinção da demissão sem justa causa e a concessão de estabilidade no emprego durante um ano aos maridos de esposas grávidas, são duramente criticados por representantes do discurso do empresariado na mídia ${ }^{1}$.

Notadamente fica a intenção de determinados textos jornalísticos, publicados por significativos veículos de comunicação no país, em deslegitimar propostas de alteração das leis a favor da proteção do trabalhador. Argumentam que possíveis mudanças nesta direção, na verdade, seriam prejudiciais ao próprio trabalhador, visto que diminuiriam a criação de postos de trabalho devido ao aumento de custos das empresas. Isso, porém, não significa que as organizações estejam contra a modernização das leis trabalhistas, pelo contrário, são os principais grupos da sociedade que a defendem. No entanto, seus interesses parecem ser outros ao pressionar o governo, sindicatos e os próprios trabalhadores a aceitarem as relações trabalhistas "flexíveis" que possam permitir "negociações" diretas entre organizações e

\footnotetext{
${ }^{1}$ Veja, por exemplo, a matéria da revista Exame intitulada "Só faltava essa" (publicada em 31 dez. 1998, edição 934, ano 42, n.25) que trata sobre a questão do trabalho no país. Nesta matéria, o periódico tenta claramente convencer o leitor da legitimidade de seu ponto de vista que defende a "flexibilização" das relações de trabalho que, a nosso ver, interessa prioritariamente à classe empresarial. Faz isso ao criticar com veemência as propostas de projetos governamentais que possam privilegiar a condição do trabalhador no país.
} 
trabalhadores $^{2}$ com respaldo do afrouxamento das condições legais de trabalho. O empresariado sugere como saída para uma diminuição das demissões, ou até mesmo, uma tentativa de evitá-las, a "flexibilização" dos contratos de trabalho. Observa-se que a discussão sobre uma revisão das leis trabalhistas, neste sentido, ganha força neste período de crise econômica mundial da atualidade. É um momento bastante propício para se tentar impor interesses privados acima de interesses públicos, com o aval da naturalização de um discurso civilizatório em prol do bem-estar comum.

Este cenário precisa ser analisado com bastante cautela, já que as organizações, num embate político, têm significativa força e procura brechas legais para fazer valer seus interesses. Poderíamos destacar como exemplo disso a possibilidade das organizações em diminuir em até $25 \%$ do salário do trabalhador ${ }^{3}$. Não obstante, isso só é permitido legalmente para as empresas que realmente consigam comprovar que estão em dificuldades financeiras graves, o que nem sempre é o caso. Muitas organizações têm utilizado a crise econômica mundial como pretexto para justificar a necessidade deste tipo de atitude. Mesmo que não estejam enfrentando uma situação financeira problemática, sabendo que há outras saídas diferentes daquelas de diminuição de postos de trabalho, dentre as medidas cabíveis para a sua própria manutenção, certas empresas têm preferido utilizar alternativas que somente a elas interessam de fato.

Não estamos negando que as negociações entre trabalhadores e organizações possam ser necessárias e possíveis em determinadas situações, como, por exemplo, em prol da busca de alternativas que diminua o desemprego no país. Por outro lado, isso não pode ser justificativa para uma maior precarização das relações de trabalho.

O trabalhador, hoje, já faz parte de um contexto de condições degradantes de trabalho. Nota-se, por um lado, que os trabalhadores brasileiros têm uma carga horária cada vez mais extenuante - em geral, são mais de 8 horas de trabalho, com horas extras e imposições implícitas para que possa manter-se no emprego por mais tempo do que foi acordado na ocasião de sua contratação. Por outro lado, percebe-se que outras pessoas têm

\footnotetext{
${ }^{2}$ Entende-se "trabalhadores" neste estudo como qualquer pessoa que disponha de sua mão-de-obra para uma organização em troca de remuneração, excluindo os gestores da organização e os funcionários da alta administração. Para saber mais sobre esta diferenciação, veja Antunes (1999; 2005).

${ }^{3}$ Conforme o que designa o artigo $2^{\circ}$, da lei no 4923, de 23 dez. 1965, é possível haver acordos com os sindicatos de trabalhadores a fim de reduzir a jornada de trabalho e, consequentemente, o salário dos funcionários de empresas, caso estas últimas comprovem estar em dificuldade financeira.
} 
grande dificuldade em encontrar trabalho e são obrigadas a aceitar, quando existem, opções de empregos temporários, "flexíveis" e sem os direitos de trabalhador respeitados.

O caráter de flexibilização do trabalho é perceptível nas formas de gestão produtiva das organizações, contribuindo para uma "nova morfologia do trabalho", expressão pensada pelo professor e pesquisador Ricardo Antunes. Ele traz à tona um discurso que mostra a ampliação do número de trabalhadores terceirizados, exercendo trabalhos temporários e de regime part time, além de outras formas que configuram o trabalho informal. A este tipo de trabalhador que caracteriza a nova morfologia do trabalho, juntamente com os tradicionais assalariados urbanos (da indústria e das empresas de serviços) e rurais, acrescentam-se também os operadores de telemarketing e os motoboys, dentre outras categorias profissionais.

Em busca da qualidade, competência, conhecimento e competitividade no mercado, as organizações têm instituído formas contemporâneas de gestão que aumentam ainda mais a degradação das relações de trabalho. Muitos dos elementos que compõem o “toyotismo", por exemplo, tem sido agentes neste sentido.

Entendido como uma nova possibilidade de reestruturação produtiva do capital (ANTUNES, 1999), o modelo japonês de gestão produtiva chamado de "toyotismo" alcançou grande aceitação nos países desenvolvidos, a partir principalmente da década de 1970, como os Estados Unidos e a Europa, e mais tarde nos países considerados em desenvolvimento, como é o caso do Brasil.

A década de 1990, em nosso país, é marcada pela apropriação dos preceitos do "toyotismo" por várias organizações que se apoiaram nos elementos da modernização tecnológica, qualidade total, polivalência e multifuncionalidade do trabalhador, competências e gestão do conhecimento. Deste modo, as relações de trabalho começaram a seguir determinados direcionamentos, como esclarece Oliveira:

"Na década de 1990, o cenário da acumulação capitalista se conformava pelo discurso da globalização, a abertura da economia para os mercados externos com a redução das alíquotas de importação e o processo de enxugamento das empresas combinando gestão de inspiração japonesa e novas tecnologias, que concentravam no descarte da força de trabalho a possibilidade de redução de custos." (2004, p.123).

A flexibilização das formas de acúmulo do capital ganhou mais espaço neste cenário de muitas mudanças, influindo fortemente nas relações entre trabalhadores e 
organizações. Neste horizonte, por exemplo, ressalta-se a intensificação da tentativa de mobilização da subjetividade do trabalhador pelas organizações. A busca pelo controle da dimensão cognitiva do trabalhador aumenta por parte dos empregadores, já que se mostra essencial para o bom funcionamento das organizações. Nesta nova configuração de relações produtivas, em que se observa a crescente automatização das empresas, o saber dos funcionários começa a ser alvo de interesse das formas de gestão administrativa (ANTUNES, 1999; 2005). Se o fordismo concebia a separação rígida entre elaboração (gerência) e execução (operário) do trabalho, o toyotismo, por outro lado, incentiva o funcionário a interferir no processo produtivo, motivando-o a ser mais proativo, a oferecer sugestões que melhore o funcionamento da empresa e que esteja atento aos problemas que podem dificultar o êxito do trabalho.

As organizações, neste sentido, começam a exigir maior envolvimento dos funcionários na vida da organização. Não mais se admite que o trabalhador esteja focado somente na sua função. As empresas esperam dele que saiba desenvolver muito bem suas tarefas, mas que, também, possa envolver-se em trabalhos de outras áreas e departamentos da organização. Exemplo disso são os círculos de qualidade total e os trabalhos em equipe interdepartamentais. Ao funcionário é solicitado que saiba mais sobre o negócio da organização e sinta-se parte dela. Além disso, as organizações buscam mobilizar a subjetividade do trabalhador por meio da aceitação das diretrizes organizacionais. A moral da empresa, ou seja, seus valores, sua visão e sua missão são disseminados fortemente no ambiente de trabalho para que os empregados sejam convencidos a agir em prol dos interesses organizacionais (LINHART, 2007).

Este breve panorama sobre as relações entre organizações e trabalhadores demonstra um olhar calcado em reflexões críticas de estudos do campo da sociologia do trabalho, o qual busca compreender, dentre outras preocupações, as possíveis contradições de interesses que existem na interação destes dois agentes sociais, bem como as diversas transformações ocorridas no mundo do trabalho na contemporaneidade. Por meio da leitura de obras de autores representativos deste campo de conhecimento, percebemos que suas ponderações poderiam contribuir para reflexões valiosas sobre os estudos de "comunicação interna”, desenvolvidos na área da comunicação organizacional. 


\section{Questões em torno do problema de pesquisa}

Os estudos de "comunicação interna", abarcados pela área da comunicação organizacional, no geral, preocupam-se em pensar as relações entre trabalhadores e organizações com base nos processos comunicativos que podem oferecer algum tipo de aplicabilidade às práticas profissionais de comunicação em empresas ${ }^{4}$. Este cenário nos motiva a pensar em alguns questionamentos: a) a área da comunicação organizacional estaria interessada em refletir sobre as mudanças no mundo do trabalho e possíveis interferências oriundas destas transformações no modo de pensar o processo comunicativo nas organizações?; b) há vontade em se pensar qual é o lugar da comunicação nas relações entre trabalhadores e organizações diante das mudanças ocorridas no mundo do trabalho? Estes enunciados despertaram-nos significativo interesse, incentivando-nos a desenvolver as análises que configuraram esta dissertação.

Com o auxílio especialmente de estudos oriundos da sociologia do trabalho, o objetivo principal desta dissertação é analisar criticamente a ótica que significativas vozes autorais e a voz institucional da Associação Brasileira de Comunicação Empresarial (ABERJE), dentro da área da comunicação organizacional, têm sobre a relação entre trabalhadores e organizações. Refere-se a uma análise crítica que tenta contribuir para a reflexão do próprio campo de estudos que, a nosso ver, tem se construído com força maior centrada na dimensão estratégica da comunicação na busca de alternativas para o melhor funcionamento das organizações.

Houve a preocupação de nossa parte em conhecer as correntes de pensamento de comunicação organizacional que, de uma forma ou de outra, tratam sobre as relações entre trabalhadores e organizações. Isto foi articulado de maneira mais abrangente, ou seja, a partir de traços do que denominamos de discurso hegemônico desta área de conhecimento e, também, por meio de estudos específicos de "comunicação interna". Tais abordagens teóricas mostraram-se essenciais para muitas das análises expostas aqui. Adianto, entretanto, que esta dissertação não é um estudo de comunicação organizacional - ou de "comunicação interna” que sugere algum tipo de aplicabilidade prática ou profissional do que será analisado. Trata-se,

\footnotetext{
${ }^{4}$ Vale destacar que o termo "organização" é utilizado neste texto para referir-se a qualquer tipo de organização, seja de natureza privada (empresa), pública ou estatal e sem fins lucrativos. Isso significa que quando estivermos usando a palavra “empresa” também podemos estar nos referindo à “organização", de forma ampla.
} 
como veremos à frente, de uma análise crítica de vozes envolvidas no debate da área de comunicação organizacional, mais especificamente sobre a "comunicação interna".

Antes de prosseguirmos, cabe fazermos alguns esclarecimentos que possam ajudar no entendimento desta dissertação. Ressalto que não são todas as idéias correntes dos estudos da comunicação organizacional que assumimos. Por outro lado, admitimos algumas especificidades desta área de conhecimento que tangenciam o objeto do nosso estudo. Há manifestações relevantes deste campo que devemos reconhecer para que esta dissertação de mestrado seja considerada um estudo ligado à comunicação organizacional. Desta forma, levantamos duas questões. Primeiramente, entendemos que não é possível ignorarmos que a área de comunicação organizacional toma para si as discussões acerca do processo de comunicação nas relações de trabalho como um objeto de estudo próprio, representado pelos estudos de "comunicação interna". Para exemplificar, podemos citar dois autores com uma inserção no âmbito científico indiscutível, cujas obras destacam a necessidade de se levar em consideração as relações entre trabalhadores e organizações por meio da comunicação. Estamos falando de Margarida Maria Krohling Kunsch e Gaudêncio Torquato. Ambos, considerados representativos estudiosos da área, compreendem comunicação organizacional, de maneira geral, como um conjunto de atividades que integram o processo de comunicação entre a organização e os indivíduos que interagem com ela. Deste modo, demonstram um forte interesse quanto ao processo comunicacional nas relações de trabalho em organizações. Em segundo lugar, os estudos da comunicação organizacional demonstram sua relevância na medida em que apresentam uma posição de destaque no que se referem às discussões sobre a interação entre trabalhadores e organizações nos cursos de graduação em comunicação social, especialmente na habilitação de relações públicas, e nos cursos de pós-graduação lato sensu que objetivam tornar o aluno um especialista em gestão da comunicação.

Com o propósito, portanto, de realizar uma análise crítica sobre como certas vozes da comunicação organizacional enxergam as relações entre funcionários ${ }^{5}$ e organizações, escolhemos dois objetos de análise com seus respectivos corpus. O primeiro objeto refere-se às correntes de pensamento da área acadêmica da comunicação organizacional, as quais são representadas nas produções científicas. São obras de destaque do pensamento acadêmico atual da comunicação organizacional, compreendidas como um dos nossos corpus de análise.

\footnotetext{
${ }^{5}$ É importante destacar que, nesta dissertação, utilizaremos os termos "funcionários" e "empregados" como sinônimos de "trabalhadores".
} 
Houve a preocupação de nossa parte em apresentar, sob o nosso ponto de vista, os aspectos mais recorrentes do discurso destas vozes autorais da comunicação organizacional no Brasil, bem como de estudos mais específicos que tratam diretamente sobre a relação entre trabalhadores e organizações, isto é, de "comunicação interna". As constatações decorrentes das análises deste objeto nos auxiliaram a conhecer concepções teóricas que a área tem em relação ao processo comunicativo nas organizações e das relações destas com os trabalhadores. Já o segundo objeto de análise utilizado nesta dissertação diz respeito à ABERJE, visto que ela tem significativa inserção no campo acadêmico da comunicação organizacional, contribuindo para a legitimação da produção de conhecimento da área em questão.

Inicialmente criada para auxiliar na sistematização das publicações empresariais, em 1967, a ABERJE hoje atua de forma contundente como mediadora de debates de temas contemporâneos da comunicação organizacional, quanto às práticas profissionais e aos estudos acadêmicos, através de eventos, cursos de aprimoramento profissional, pesquisas, publicações, premiações, dentre outras ações, como Kunsch (2006) destaca.

Em seus 40 anos de existência, a ABERJE apresenta um relevante papel para a evolução da comunicação organizacional no Brasil. Possui mais de 1.000 organizações associadas e consegue articular relacionamentos entre profissionais e especialistas acadêmicos em âmbito nacional e internacional. Congrega núcleos de representação e atuação no Amazonas, em São Paulo (capital e interior), no Espírito Santo, em Minas Gerais, no Paraná, no Rio de Janeiro, no Rio Grande do Sul e em Santa Catarina.

E um ponto a ser destacado em prol da escolha da ABERJE, como um interessante objeto de análise para esta pesquisa, deve-se ao fato de suas tentativas de atuação como difusora de práticas excelentes de "comunicação interna", em que a educação para o aperfeiçoamento profissional é o grande eixo da instituição. Ela promove um grande número anual de eventos - seminários, conferências, debates e palestras -, além de outras atividades como premiações e realização de pesquisas. A associação conta ainda com uma editora, a ABERJE Editorial, que tem publicado títulos de grande interesse para a área de comunicação organizacional, inclusive de "comunicação interna". Estas publicações, aliás, têm sido utilizadas constantemente em cursos de graduação e pós-graduação relacionados à comunicação organizacional.

A partir da escolha da ABERJE, optamos pela revista Comunicação Empresarial como corpus de análise. Este periódico é publicado trimestralmente pela associação e dentre 
suas matérias existem muitas que tratam diretamente sobre "comunicação interna", representando a visão que a ABERJE tem sobre as relações entre trabalhadores e organizações.

É importante reafirmar que a ABERJE nos interessa como objeto de análise na medida em que seus preceitos têm sido incorporados às discussões acadêmicas e aos estudos de comunicação organizacional. Caso isso não acontecesse, certamente a ABERJE não seria utilizada aqui, visto que sua atuação estritamente no campo profissional não é o principal interesse em nossa abordagem.

\section{Passos metodológicos}

Neste momento trataremos sobre as questões metodológicas do desenvolvimento desta dissertação, isto é, a seguir serão expostos os passos necessários para as análises do corpus da pesquisa. Inicialmente, vale destacar que as análises foram realizadas com significativo interesse em compreender os discursos balizadores da ótica da área da comunicação organizacional no Brasil sobre as relações entre trabalhadores e organizações. Embora não seja, stricto sensu, uma abordagem baseada na Análise do Discurso, houve um empenho em entender certas vozes recorrentes na formação do discurso desta área, ajudando-nos a conhecer a sua concepção sobre a relação entre organizações e empregados.

O primeiro passo para as análises do corpus deu-se com o levantamento das principais fontes bibliográficas do campo científico da comunicação organizacional no Brasil. Optou-se por utilizar autores nacionais de livros que são utilizados em cursos de graduação e pós-graduação em universidades do país quando o tema estudado refere-se à comunicação organizacional. Foi realizada uma investigação das fontes que desenvolvessem de alguma forma articulações com os aspectos da "comunicação interna”. A partir disso, escolhemos algumas obras de quatro estudiosos da comunicação organizacional, das quais foram feitas leituras críticas que puderam nos guiar na análise do que denominamos de discurso hegemônico desta área.

O segundo passo referiu-se ao levantamento e à leitura crítica dos estudos propriamente ditos de "comunicação interna", fixando-nos em dois autores representativos, cujos estudos nos possibilitaram um melhor entendimento sobre o discernimento que a área 
da comunicação organizacional tem sobre relações estabelecidas entre organizações e trabalhadores por meio do processo comunicativo.

Já o terceiro passo para a realização das análises deu-se com o levantamento das principais matérias da revista Comunicação Empresarial. A partir dos eixos temáticos estudados no capítulo III, isto é, apoiando-se nas reflexões do campo da sociologia do trabalho, foram lidas 65 edições da revista na íntegra, publicadas no período de 1991 a 2007. Após isso, foram escolhidos os principais textos que trazem discussões significativas sobre "comunicação interna" e que, de alguma forma, tratam diretamente sobre a relação entre trabalhadores e organizações. Com este material em mãos, foram realizadas as análises pertinentes ao objetivo principal desta dissertação.

É possível dizer que nossas investigações estão baseadas, em certa medida, nas orientações do referencial metodológico nomeado de "hermenêutica de profundidade", o qual é entendido pelo pesquisador John B. Thompson (1995) como uma "metodologia da interpretação". Em linhas gerais, a hermenêutica de profundidade busca analisar formas simbólicas inseridas em condições sociais e históricas específicas. Sob esta luz, compreende-se o objeto de análise das pesquisas sociais como construção de significados que mereça algum tipo de interpretação. Interpretação, esta, mediada, em grande parte, pela análise da ideologia relacionada às formas simbólicas estudadas.

Thompson (1995) compreende a hermenêutica de profundidade como um referencial metodológico baseado em três procedimentos que possibilitam a análise das formas simbólicas: análise sócio-histórica, análise formal ou discursiva e interpretação/reinterpretação. Sob o ponto de vista do autor, múltiplos são os métodos que podem ser utilizados em cada um destes procedimentos. A escolha deles dependerá do objeto específico de análise e das particularidades de cada investigação.

A análise sócio-histórica, entendida por Thompson (1995) como a primeira fase do foco da hermenêutica de profundidade, busca "reconstruir as condições sociais e históricas de produção, circulação e recepção das formas simbólicas” (THOMPSON, 1995, p.366). O autor sugere quatro aspectos destas condições como fundamentais para a análise das formas simbólicas: as situações espaço-temporais exclusivas; os determinados campos de interação; as instituições sociais e a estrutura social (identificação das diferenças de indivíduos e de grupos na sociedade quanto ao acesso a recursos e distribuição de poder, por exemplo). Este último aspecto parece ser um dos mais representativos para a análise, visto que, de acordo com 
Thompson: "a análise da estrutura social demanda, pois, um nível de reflexão mais teórico, pois exige que o analista proponha critérios, formule categorias e faça distinções que ajudem a organizar e iluminar a evidência das assimetrias e diferenças sistemáticas da vida social" (1995, p.367).

Thompson resume muito bem seu entendimento sobre o que ele chama de primeira fase de análise do enfoque da hermenêutica de profundidade (HP):

\footnotetext{
"A tarefa da primeira fase do enfoque da HP é reconstruir as condições e contextos sócio-históricos de produção, circulação e recepção das formas simbólicas, examinar as regras e convenções, as relações sociais e instituições, e a distribuição de poder, recursos e oportunidades em virtude das quais esses contextos constroem campos diferenciados e socialmente estruturados." (THOMPSON, 1995, p.369).
}

Procuramos, ao longo do desenvolvimento desta dissertação de mestrado, contextualizar as correntes de pensamento da área da comunicação organizacional no Brasil ao oferecermos uma discussão dos momentos históricos e sociais decisivos para sua formação, bem como ao tentarmos revelar a configuração de um discurso hegemônico desta área de conhecimento. Ainda, nos atentamos em refletir sobre as mudanças no mundo do trabalho a partir dos estudos desenvolvidos sob o olhar do campo da sociologia do trabalho. E, não com importância menor, houve o cuidado de nossa parte em discorrer sobre os aspetos fundamentais da ABERJE, especialmente no que tange a sua significativa influência na formação da área de comunicação organizacional no Brasil.

A segunda fase de análise do enfoque da HP, proposta por Thompson (1995), refere-se à análise formal e discursiva, como citamos anteriormente. A necessidade do cumprimento desta fase, sob o ponto de vista do autor, deve-se ao fato que "os objetos e expressões que circulam nos campos sociais são também construções simbólicas complexas que apresentam uma estrutura articulada" (THOMPSON, 1995, p.369, grifos do autor). Em outras palavras, as formas simbólicas, além de serem frutos de uma contextualização social específica, são construções simbólicas que dizem ou expressam coisas em relação a algo. A luz do pensamento deste autor, não importa qual método é utilizado pelo pesquisador para cumprir esta fase. O importante é tentar fazer uma análise dos aspectos estruturais e das relações do discurso. Thompson utiliza o termo 'discurso' de forma mais ampla para referir-se às “instâncias de comunicação correntemente presentes" (1995, p.371, grifos do autor). 
Sob este horizonte, buscamos nesta dissertação analisar a produção científica de vozes que compõem o discurso hegemônico da comunicação organizacional no Brasil por meio de quatro traços comuns em determinados autores e suas obras: (I) a comunicação como parte intrínseca ao processo de gestão organizacional; (II) a comunicação pautada por sua contribuição direta à eficácia e eficiência dos negócios das organizações; (III) a apologia do discurso da "comunicação integrada"; (IV) enfoque nas práticas profissionais para discorrer sobre o conceito de comunicação organizacional. Já para estudar as matérias da revista Comunicação Empresarial, nosso segundo objeto de análise nesta dissertação, pensamos em quatro eixos temáticos representativos das mudanças no mundo do trabalho: (I) individualização do trabalhador, (II) valorização da pessoa na organização, (III) acessibilidade à informação no ambiente de trabalho e (IV) incorporação do trabalhador à racionalidade da organização. Estes temas, é importante frisar, foram escolhidos a partir de uma reflexão teórica baseada nos estudos do campo da sociologia do trabalho.

Aqui vale uma ressalva importante. Ao tentarmos esclarecer como as duas fases discutidas até agora foram abordadas ao longo desta dissertação, há a intenção de nossa parte em exemplificar os momentos em que estas fases ficaram mais evidentes. Não poderia servir para outro fim, visto que as fases do processo metodológico da hermenêutica de profundidade ocorrem em concomitância e não de forma fragmentada.

A terceira e última fase do enfoque da hermenêutica de profundidade é nomeada por Thompson (1995) como "interpretação/reinterpretação". Em primeira instância, essa fase é entendida pelo autor como um complemento à análise discursiva, visto que o processo de interpretação desenvolve-se com base nos resultados da análise formal. Na verdade, o processo de interpretação, conforme o ponto de vista do autor, depende da contextualização sóciohistórica e da análise formal das formas simbólicas. Por outro lado, considera que a interpretação ultrapassa os métodos destas duas análises ao tentar trazer à tona a representatividade do que é enunciado pelas formas simbólicas.

$\mathrm{O}$ autor entende a interpretação como um processo também de reinterpretação, visto que as formas simbólicas - objetos de análise - já foram interpretadas pelos sujeitos que as formaram, sob suas condições sócio-históricas. Deste modo, o analista estaria reinterpretando campos sociais já interpretados. Isso significa que corremos o risco de atribuir um significado diferente daquele construído por estes sujeitos, gerando possíveis discussões e embates. 
Thompson completa este pensamento ao afirmar "a possibilidade de um conflito de interpretação é intrínseco ao próprio processo de interpretação" (1995, p.376).

As interpretações/reinterpretações que realizamos dos objetos de análise desta dissertação, isto é, da produção científica de vozes autorais da comunicação organizacional e da revista Comunicação Empresarial, representando a voz institucional da ABERJE, certamente produzirão reações de concordância, mas, também, contrárias ao que foi pensado por nós. Isto ocorrerá até mesmo porque, de certa forma, nosso processo de análise também aborda os aspectos ideológicos destes objetos.

Sob o ponto de vista de Thompson (1995), quando o analista se interessa em refletir criticamente sobre seus objetos de análise, procurando entender como estes instituem e conservam as relações dominantes de poder, o processo de interpretação assume o caráter de análise ideológica. A interpretação, neste sentido, também contribui para sintetizar a análise das condições sócio-históricas e a análise formal ou discursiva das formas simbólicas ao revelar como estas estão inseridas neste cenário. Este tipo de reflexão pode motivar debates interessantes, pois:

“(...) a interpretação da ideologia pode levantar reações violentas, ela atinge os nervos do poder, ela coloca em evidência as posições dos que se beneficiam e dos que sofrem as relações sociais que são assimetricamente estruturadas, ela deixa claro o que, muitas vezes, permanece implícito, tido como certo, ou oculto no comportamento diário da vida social." (THOMPSON, 1995, p.416).

Em síntese, as opções metodológicas escolhidas para o desenvolvimento dessa dissertação nos auxiliaram a refletir criticamente sobre a ótica que determinadas vozes da comunicação organizacional no Brasil têm sobre as relações entre trabalhadores e organizações, buscando evidenciar certas assimetrias existentes nas relações sociais que permeiam os nossos objetos de análise. 


\section{A estrutura da dissertação}

Para se alcançar o objetivo principal já exposto anteriormente, a estrutura desta dissertação é composta por quatro capítulos.

No capítulo I, discorremos, num primeiro momento, sobre alguns aspectos formadores do campo da comunicação organizacional no Brasil, principalmente, a partir de certas características da atividade de relações públicas que o ajudaram a se configurar como uma área marcada pela preocupação com o bom funcionamento das organizações. Em seguida, analisamos alguns traços comuns dos pensamentos de quatro estudiosos representativos do campo científico brasileiro da comunicação organizacional (Margarida Maria Krholing Kunsch, Francisco Gaudêncio Torquato do Rego, Wilson Bueno e Paulo Nassar) que formam o que denominamos o discurso hegemônico desta área. Em complemento a este capítulo, também trazemos algumas perspectivas teóricas da comunicação com o propósito de, primeiramente, compreender certo descompasso de determinados entendimentos que a área da comunicação organizacional tem em relação às atuais teorias da comunicação. Em segundo lugar, são trazidas à tona algumas possibilidades de se repensar a comunicação organizacional.

O capítulo II tem a intenção de expor e analisar alguns importantes aspectos que concebem os estudos de "comunicação interna" a partir, especialmente, das idéias de determinados estudiosos que mostram grande interesse em suas produções científicas em discutir a função dos processos comunicativos internos às organizações. Somam-se, assim, mais algumas pistas sobre qual é o entendimento que significativas vozes da área da comunicação organizacional têm sobre a relação entre trabalhadores e organizações.

Já no capítulo III, trazemos algumas considerações do campo da sociologia do trabalho que nos auxiliam a refletir criticamente sobre as mudanças no mundo do trabalho e as relações entre trabalhadores e organizações. É neste momento que esclarecemos a nossa opção em pensar a comunicação a partir do fator trabalho, entendendo que este é um elemento central nas relações sociais. Também, neste capítulo, tentamos discorrer teoricamente sobre determinados eixos temáticos que serão utilizados como critérios de análise das matérias da revista Comunicação Empresarial, publicada pela ABERJE. 
Finalmente, no último capítulo, procuramos demonstrar porque a ABERJE foi escolhida como um dos objetos de análise desta dissertação ao demonstrarmos sua força institucional no campo científico da comunicação organizacional no Brasil. E, em seguida, analisamos criticamente as matérias escolhidas da revista Comunicação Empresarial. 


\section{Comunicação organizacional: aspectos da trajetória brasileira}

Os conceitos de comunicação organizacional são apresentados de diversas formas por estudiosos representativos desta área de conhecimento no Brasil. Cada um deles, ao seu modo, tenta atribuir uma explicação ao significado de comunicação organizacional, abarcando tanto os aspectos teóricos como os aspectos profissionais da área. As linhas de investigação e os objetos de estudos são múltiplos. Nota-se, principalmente, que as práticas profissionais têm sido fortes norteadoras das reflexões teóricas da área, visto o grande interesse dos pesquisadores em encontrar respostas para problemas de ordem pragmática, correndo o risco, muitas vezes, de distanciarem-se de um olhar crítico necessário para o avanço do conhecimento científico.

Apesar da heterogeneidade de $\operatorname{estudos}^{6}$ que integram a comunicação organizacional, a área desenvolve-se ainda sob forte influência de uma corrente de pensamento interessada em administrar e gerar resultados para demandas específicas de gestão organizacional. Sob este horizonte, é possível verificar a existência de alguns traços que marcam um discurso hegemônico desta área orientado pela dimensão estratégica, como veremos à frente.

Conhecer alguns aportes fundamentais da formação do campo brasileiro de estudos de comunicação organizacional certamente mostra-se importante para esclarecer como esta área tem se apresentado. Este capítulo, portanto, busca uma breve contextualização sobre este campo, tal como é concebido por seus estudiosos, traçando sempre que possível e de

\footnotetext{
${ }^{6}$ É possível encontrarmos alguns significativos estudos brasileiros, já publicados, que mostram, em certa medida, interesse em analisar a comunicação organizacional sob outros vieses que não os centrados na busca de respostas para os problemas de gestão estratégica do processo comunicativo em organizações. Confira, por exemplo, os livros de autores como Baldissera (2000) e Oliveira; Soares (2008). Por outro lado, este fato não contraria a hipótese que grande parte dos estudos brasileiros que integram a área sejam pautados pela dimensão estratégica da comunicação organizacional.
} 
forma pertinente, comentários críticos que facilitem as reflexões a serem estabelecidas no decorrer desta dissertação. Faz-se necessário elucidar que não se pretende desenvolver aqui uma revisão de literatura deste campo científico. Até mesmo porque, outros estudiosos já contribuíram neste aspecto ${ }^{7}$. Sabemos que diversos são os fenômenos comunicacionais nas organizações alvos de análises por parte de pesquisadores brasileiros. Constata-se que uma considerável gama de trabalhos científicos tem contribuído para a formação teórica desta área, mas neste momento, em relação a este estudo, não interessa abarcarmos sua dimensão abrangente e sim seus pontos mais marcantes que formulam o que se poderia dizer como discurso hegemônico.

$\mathrm{Na}$ tentativa de refletir criticamente sobre o discurso hegemônico da área, serão explicitados alguns traços comuns dos pensamentos de determinados estudiosos brasileiros representativos.

Com o propósito de aprofundar esta reflexão crítica, optamos ainda por apresentar perspectivas de comunicação que possam contribuir para novos caminhos em se repensar a área da comunicação organizacional.

Este capítulo da dissertação, de forma ampla, mais do que uma proposta de apresentação dos esquemas teóricos de uma área, é fundamental para situar o leitor quanto às nossas recusas e concordâncias em relação ao assunto.

\subsection{Momentos decisivos da formação do campo da comunicação organizacional no Brasil}

O delineamento do campo profissional da comunicação organizacional, no Brasil, dá-se em meados da década de 1950 com o despontar das atividades de relações públicas e de jornalismo empresarial. Nesta época, algumas organizações, especialmente empresas privadas multinacionais estrangeiras alocadas no país, começaram a se interessar por instrumentos de comunicação que pudessem contribuir para informar sobre suas ações àqueles que lhe interessavam.

\footnotetext{
${ }^{7}$ Margarida Maria Krohling Kunsch, por exemplo, apresenta um panorama abrangente deste campo em livros e textos seus. Cf.Kunsch (1997; 1999; 2003a; 2005).
} 
O jornalismo empresarial no Brasil, entendido como a produção de jornais, revistas, boletins, ou seja, materiais de cunho noticioso, especialmente direcionados aos empregados da organização, começou a se destacar entre os anos 1940 e 1950. Conforme expressa o estudioso da área de comunicação organizacional Torquato (1984), muitas empresas já produziam este tipo de material nesta época, mas poucas, segundo seu ponto de vista, faziam de forma competente.

A partir dos anos 1960, a comunicação organizacional como prática profissional recebe grande atenção de empresários e profissionais interessados em estabelecer canais de informação com clientes, empregados, dentre outros grupos de pessoas que se relacionavam com as organizações. Os primeiros departamentos de relações públicas foram criados e as publicações produzidas pelas organizações, especialmente os jornais de empresa, tinham grande representatividade no rol de ações de comunicação que os profissionais começavam a pensar em contribuição ao crescimento das empresas no cenário social brasileiro. Neste período, boa parte da atenção de profissionais de comunicação em organizações voltava-se para os esforços quanto ao aprimoramento das técnicas de desenvolvimento deste tipo de publicação, sendo o conteúdo editorial e o planejamento gráfico as suas principais preocupações.

Ainda na década de 1960, o jornalismo empresarial ganhou reforço com a criação de uma representativa associação, na época nomeada de Associação Brasileira de Editores de Revistas e Jornais de Empresas (ABERJE). Na ocasião da I Convenção Nacional de Editores de Revistas e Jornais de Empresas, os participantes, em sua maioria editores de publicações empresariais, aprovaram a fundação da ABERJE em 1967 com os principais objetivos de: defender os interesses da classe, desenvolver mais eventos para discussão sobre a área de jornalismo empresarial e buscar uma melhoria na qualidade da produção de publicações de empresas (KUNSCH, 1997).

A ABERJE, denominada, a partir de 1989, Associação Brasileira de Comunicação Empresarial, é considerada forte influente no desenvolvimento da comunicação organizacional no Brasil, seja no campo profissional, seja, por conseqüência, no campo acadêmico. Veremos que o limite entre os dois campos nem sempre é tão nítido quanto se parece. Deve-se sublinhar 
que é consenso entre os principais estudiosos da área ressaltar o papel da ABERJE como grande colaboradora para o desenvolvimento da comunicação organizacional no Brasil ${ }^{8}$.

É interessante notar que a literatura brasileira sobre comunicação organizacional destaca os acontecimentos e fatos ocorridos na atuação dos profissionais desta área, e a atenção que o empresariado começa a dar à comunicação em seus negócios, como propulsores da formação de um campo de conhecimento e, consequentemente, de seu aspecto téorico.

Alguns dos principais estudiosos da área (KUNSCH, 1997; NASSAR, 2001; BUENO, 2003) destacam como o primeiro estudo brasileiro sobre comunicação organizacional a tese de doutorado defendida por Gaudêncio Torquato na Escola de Comunicações e Artes da Universidade de São Paulo datada de $1972^{9}$. Ou seja, antes disso, o campo de conhecimento sobre comunicação organizacional no país ganha corpo por meio das práticas de profissionais que desenvolviam especialmente atividades de jornalismo e de relações públicas, além de alguns eventos como cursos de curta duração e nos poucos cursos universitários destas profissões que existiam no país nas décadas de 1960 e início de 1970.

É possível afirmar que o campo acadêmico da comunicação organizacional no Brasil, a partir da década de 1990, continua ainda sendo fortemente pautado pelas práticas profissionais e por uma orientação pragmática na busca pela melhor contribuição para o funcionamento das organizações. Isto é perceptível nas principais obras (livros) deste campo e pela inserção das idéias da própria ABERJE em cursos de graduação e pós-graduação, de importantes universidades brasileiras, sobretudo os que abarcam os estudos de comunicação organizacional, tais como Relações Públicas, Jornalismo, Comunicação Empresarial, Publicidade e Propaganda, Marketing.

Na busca de uma compreensão sobre a formação inicial da comunicação organizacional, a atividade de relações públicas apresenta-se como uma de suas principais precursoras (KUNSCH, 1997). Focalizemos nela neste momento.

O primeiro curso regular de relações públicas no Brasil foi realizado por meio da iniciativa da ONU - Organização das Nações Unidas - e da EBAP - Escola Brasileira de Administração Pública da Fundação Getúlio Vargas -, em 1953. Como instrutor deste curso foi convidado o professor americano Eric Carlson. Após este, outros cursos foram ministrados nas décadas de 1950 e 1960. Destaca-se a presença do professor Harwood L. Childs, da

\footnotetext{
${ }^{8}$ Cf. Kunsch (1997; 2003b); Nassar (2001; 2008a); Bueno (2003); Torquato (2004); Oliveira; De Paula (2007).

${ }^{9}$ A tese de Gaudêncio Francisco Torquato do Rego é considerada como obra pioneira no campo teórico da comunicação organizacional no Brasil e sua versão em livro foi publicada pela Summus Editorial, em 1984.
} 
Universidade de Princeton, nos EUA, vindo lecionar durante um ano para os iniciantes nos estudos acadêmicos desta área. Ressaltam-se ainda outras instituições brasileiras pioneiras no oferecimento de cursos de relações públicas no país, entre elas: DASP - Departamento Administrativo do Serviço Público, a Escola de Serviço Público do então Estado da Guanabara, o Instituto de Organização Racional do Trabalho (IDORT) de São Paulo, Instituto Promovendas do Ensino Técnico (IPET) do Rio de Janeiro.

Podemos perceber, conforme as indicações deixadas por Sylla M. Chaves, em artigo de 1963, que as relações públicas, conceitualmente, começam a se despontar, nesta época, como uma função administrativa. Naquele momento, esta seria uma função, que poderia ser aplicada tanto em organizações privadas como, também, no serviço público (estatal) e seu principal objetivo a ser alcançado era, segundo Chaves (1963): a integração com o interesse público. Vale destacar aqui que Peruzzo (1986), anos mais tarde, reflete criticamente sobre o objetivo das relações públicas em caracterizar o interesse privado como sendo de interesse de toda a sociedade, ou seja, de interesse público. A autora explica que “considerar interesse público como 'um fim em si mesmo’ é reificação, ou seja, está se fetichizando a existência do interesse público em si. O interesse público não é em si, porque o social é histórico, resultando da dinâmica das relações sociais." (PERUZZO, 1986, p.35).

É interessante notar que, desde o início, vide o artigo de Chaves (1963), que aqui funciona como um depoimento desta época inicial, já se enfatizava a diferenciação entre relações públicas e propaganda, como duas áreas com finalidades bem diferentes uma da outra. Enquanto a propaganda seria empregada para fins comerciais e políticos - de interesse privado e particular -, a atividade de relações públicas deveria ser direcionada à educação: “o conteúdo persuasivo de relações públicas está no terreno da educação cívica, da educação agrícola, da educação sanitária (...) Enquanto a propaganda 'forja autômatos' (...) a educação liberta, ensina a pensar por si” (CHAVES, 1963, p.11). E, segundo Chaves (1963), tal propósito também poderia ser aplicado à atividade de relações públicas em empresas privadas, cujo resultado esperado seria a integração de seus interesses com os interesses do público ${ }^{10}$.

Conforme dito anteriormente, as relações públicas começaram, então, a se delinear fortemente como uma função administrativa em prol do funcionamento de organizações. Neste sentido, segundo seus preceitos, elas auxiliam na transmissão e

\footnotetext{
${ }^{10} \mathrm{O}$ termo "público" é utilizado como aquilo que é coletivo e comum à população em geral e não ainda utilizado no plural - "públicos" como hoje é aplicado em relações públicas - grupos diferenciados de indivíduos que se relacionam com as organizações.
} 
interpretação de informações de uma organização para a população e, por outro lado, também ajudam a organização a informar-se sobre as idéias e opiniões dos indivíduos que interagem com ela, sendo que sua compreensão e seu apoio são entendidos como formas de contribuição para o êxito organizacional.

Deve-se acrescentar um dado a esta formação inicial. Até a data de 1967, ano da criação do primeiro curso superior de Relações Públicas no Brasil, na Escola de Comunicações e Artes da Universidade de São Paulo, os profissionais que pretendiam exercer a atividade de relações públicas buscavam sua formação em escolas de administração, prioritariamente, ou em instituições como o IDORT - Instituto de Organização Racional do Trabalho. O que isso significa? Percorrer a atuação do IDORT neste cenário pode nos ajudar a responder.

\subsubsection{IDORT: influências nas concepções de relações públicas}

O IDORT foi fundado em 1931 por um grupo de empresários e organizações preocupados com os problemas no mecanismo do trabalho, ou seja, com a racionalização do trabalho. Considerada como uma sociedade civil científica e sem fins lucrativos, tinha como propósitos institucionais:

"Estudar, difundir os princípios e métodos de racionalização do trabalho, no intuito de aumentar o bem-estar social, cooperando para o acréscimo da eficiência e coordenação do trabalho em todos os ramos, de modo a proporcionar às atividades produtoras de riquezas ou de serviços o máximo proveito, quer para o indivíduo, quer para a coletividade, pela elevação da produtividade e pelo maior respeito à dignidade humana." (ARAÚJO, 1965, p.3).

Observa-se que o discurso do IDORT revela sua desconsideração quanto às divergências sociais ao promover a idéia de cooperação entre trabalhadores e organizações em prol do bem-estar comum baseado na necessidade de expansão da produção e do consumo. Ao difundir os preceitos da administração científica, exaltando a racionalização, o instituto conseguia, de certo modo, disseminar práticas de dominação social interessantes à burguesia industrial da época. Vale citar o estudo de Antonacci sobre o IDORT: 
"Participando e explorando potencialidades das idéias que, fundadas no progresso científico, na ordem tecnológica, na confiança ilimitada na razão para a regeneração social e bem-estar comum, percorreram todos os tempos, espaços e instâncias sociais desde a virada do século, ideólogos do IDORT através de expressões desta natureza - trabalharam o imaginário social. Operaram com significados sócio-culturais emanados no decorrer de práticas de luta e de reflexão em torno das virtualidades libertárias e igualitárias da razão, redimensionando-os na direção de uma cultura técnico-científica em conformidade aos interesses patronais, revestidos de interesses nacionais.” (1993, p.19).

Por meio de várias atividades, como eventos, cursos, publicação da Revista de Organização e Produtividade, prestação de serviços de assistência técnica às organizações especialmente a alguns órgãos governamentais -, reuniões periódicas dos associados e de premiações - existia até mesmo o Prêmio IDORT - o instituto atuava em âmbito nacional. Gozava de prestígio frente às pessoas físicas e jurídicas interessadas em capacitarem-se para implantar ou tornar mais eficientes procedimentos de realização do trabalho com a utilização de métodos científicos.

Num momento de recente desenvolvimento industrial no país e de mudanças de características da força de trabalho, o IDORT buscava oferecer aos seus associados aportes sobre diversos temas que envolviam a racionalização do trabalho em prol do aumento da produtividade. "Relações Humanas", por exemplo, era um aspecto tratado nesta perspectiva, aparecendo com freqüência nos números da Revista de Organização e Produtividade editada pelo IDORT. É curioso notar, na leitura deste periódico, a grande preocupação dos idorteanos quanto às relações entre empregados e empregadores ou chefias, especialmente, entre os anos de 1950 e de $1960^{11}$.

O discurso idorteano quanto a este aspecto, por exemplo, é bem representativo no artigo do então integrante da diretoria do IDORT Annibal Bonfim, que foi intitulado "Relações Humanas e Produtividade". Ele inicia dizendo: "Melhorar as Relações Humanas no trabalho é um dos meios mais seguros de conseguir aumento de produtividade" (1954-1955a, p.34). Sob este prisma, o autor afirma que "Relações Humanas" constituem-se uma orientação

\footnotetext{
${ }^{11}$ Realizamos nosso levantamento nas bibliotecas da Universidade de São Paulo e concentramo-nos nas edições da revista publicada pelo IDORT entre os anos 1950 e 1960. Foram consultadas as bibliotecas das unidades da Faculdade de Administração, Economia e Contabilidade (FEA) e da Faculdade de Filosofia, Letras e Ciências Humanas (FFLCH).
} 
com o intuito de melhorar as condições de interação entre chefes e subordinados e, também, entre os trabalhadores em geral. Com o foco em encontrar meios mais propícios para aumentar a produtividade dos empregados, Bonfim (1954-1955a) defende que as necessidades subjetivas dos indivíduos merecem mais atenção do que as necessidades materiais. Pois é exatamente este o pensamento das "Relações Humanas", segundo a ótica do autor. Sua eleição está em dois tipos de necessidades subjetivas que considera mais importantes ao ser humano: primeiro, a necessidade de justiça e segundo, a necessidade de ser respeitado. Referente a esta última, Bonfim (1954-1955a) diz ser a mais complicada de lidar, visto que está ligada à "luta de classe" (termo do próprio autor). O autor esclarece com um exemplo:

"Empregados analfabetos, de capacidade de produção limitadíssima e cujo trabalho vale, portanto, muito pouco, recusam-se a comer nas cantinas onde as refeições são vendidas a preços muito inferiores ao seu valor real, dizendo com empáfia: 'Não queremos esmolas! Queremos ser bem pagos e comer o que nos agrada.” (BONFIM, 1954-1955a, p.38).

Esta é somente uma pequena amostra do discurso idorteano, prezando pela produtividade em detrimento de uma verdadeira intenção de compreensão das "necessidades subjetivas" dos trabalhadores. Levando em consideração as "Relações Humanas", Bonfim (1954-1955a, p.38) vai mais além e ressalta que as empresas:

“(...) precisam ter o cuidado especial de sempre prever, no planejamento de qualquer medida que afete os empregados, a inclusão de um serviço especial de informação, por meio do qual seja claramente feito sentir que tal medida não fere a dignidade humana. É lógico que tal informação não deverá mencionar diretamente a preocupação da administração em negar uma intenção condenável mas, pelo contrário, fazendo sentir dos empregados que esse é um meio de estimular aquela dignidade humana que eles tanto prezam.”

Nota-se que o caráter revelado pelo discurso do IDORT em relação ao "fator humano" não necessariamente demonstra a intenção em compreender os interesses dos trabalhadores prioritariamente. Observa-se, na verdade, a tentativa de ajustá-los ao ambiente de trabalho para a melhoria da produtividade. Trata-se de uma premissa de constituição do próprio instituto. A idéia central está em dificultar imensamente os meios de intervenção dos 
trabalhadores nos modos de produção. Antonacci (1993, p.122) reforça esta percepção ao afirmar que "as intenções do IDORT para com o 'fator humano' subdividiram-se em assuntos referentes à psicotécnica (adaptação do homem à máquina) e à tecnologia (adaptação da máquina e do ambiente fabril ao homem).”

As relações públicas, neste contexto, podem ser consideradas uma atividade extremamente útil aos ideais do IDORT. Annibal Bomfin (1954-1955b), agora em outro artigo, intitulado "Os serviços de Relações Públicas", destaca que a finalidade das relações públicas é contribuir para a melhoria do relacionamento entre os públicos e a alta administração da empresa através da informação que um precisa ter do outro. E afirma:

“Quando dizemos informação 'para o público’ não nos referimos apenas à iniciativa de transmitir ou comunicar fatos ou idéias, mas também ao conjunto de medidas e providências indispensáveis para garantir, tanto quanto possível, que aqueles fatos e aquelas idéias sejam aceitos, de boa vontade, como verdades indiscutíveis." (1954-1955b, p. 128).

Note-se que, a partir da edição de 1956, a Revista de Organização e Produtividade do IDORT reserva significativo espaço para discussões a respeito das relações públicas. São inúmeros artigos escritos por idorteanos que acreditavam que esta atividade poderia contribuir fortemente aos propósitos da entidade. Um dos maiores representantes das relações públicas no Brasil, Cândido Teobaldo de Souza Andrade, torna-se colunista assíduo deste periódico. Portanto, não foi por acaso que a $\mathrm{ABRP}^{12}$ - Associação Brasileira de Relações Públicas - surgiu por meio de uma iniciativa dos membros do IDORT.

\footnotetext{
${ }^{12}$ A ABRP foi fundada em 21 de julho de 1954 por meio de uma assembléia realizada na sede nacional do IDORT e muitos de seus integrantes fizeram parte da diretoria do instituto. O próprio presidente fundador da ABRP, Hugo Barbieri, era um dos diretores do IDORT na época do surgimento da associação. Supõe-se, desse modo, que as crenças do IDORT também foram incorporadas pela ABRP. E o próprio Barbieri (1956, p.80) não nos deixa mentir: “(...) da mesma forma que vós, Idorteanos, trabalhais para, através da racionalização e produtividade, construir um Brasil melhor e mais próspero, também nós profissionais de Relações Públicas, desejamos seguir vossa digna e brilhante trajetória, propugnando para que sejam sempre as melhores possíveis as relações entre os homens, nesta nossa grande e idolatrada Pátria”. Promover meios para intensificar a racionalização do trabalho era o principal propósito do IDORT e a atividade de relações públicas era vista como um destes meios. Pois, para os idorteanos, as relações públicas bem trabalhadas poderiam auxiliar no entendimento dos empregados e de outros públicos sobre a filosofia das organizações e obter o apoio destes para as suas atividades. Para eles:"É desse trabalho que se espera o bom entendimento entre os homens e as organizações que eles criaram para, satisfeitas as aspirações de uns e atingidos os fins das outras, constituirmos a alegria de todos - essa alegria própria das inteligências bem formadas que chegam facilmente à compreensão da vida em harmonia." (ARAUJO, 1965, p.3). Deve-se ainda sublinhar a grande importância dada à atividade de relações públicas pelo IDORT que, até mesmo, oferecia cursos de formação em grau médio (nível I, II e III) em relações públicas.
} 
O campo de aplicação das relações públicas, desde o início, se formou sob a égide de uma atividade presente em todos os setores da administração e conforme tal idéia, não cabe somente ao especialista de relações públicas seguir os preceitos desta atividade. É de responsabilidade de todos os trabalhadores contribuírem para a positividade das relações públicas na organização. Ou seja, começava a ser formatada a concepção, tão fortemente, hoje, estudada e aplicada, de ações planejadas de comunicação dirigidas aos empregados no ambiente de trabalho, com o intuito de tentar nortear suas atitudes frente à organização. Além disso, acreditava-se que todos os empregados deveriam ser, então, os "embaixadores das relações públicas” da organização em que trabalham (CHAVES, 1963, p.20).

Os programas de treinamentos de "relações com o público" (CHAVES, 1963, p.23) já eram incentivados para envolver os empregados com as questões institucionais da organização a fim de se tornarem os embaixadores das políticas dos relacionamentos entre a organização e os seus outros "públicos". Portanto, é possível considerar, neste sentido, que os empregados são persuadidos a contribuir para uma melhor administração organizacional.

É interessante destacar um trecho do texto de Chaves que demonstra, na época, a grande preocupação dos profissionais que desempenhavam a atividade de relações públicas com o envolvimento dos trabalhadores com a organização:

"Cabe aqui acentuar a diferença existente entre o treinamento em relações públicas, disciplina bastante vasta, como já pudemos ver e o treinamento em relações com o público, esse setor mais restrito de RP, relativo ao contato geralmente direto com indivíduos que nos coloca muito mais no campo das relações humanas que nos das relações públicas. Talvez possamos, sem impropriedade, considerar este como um dos setores em que as relações humanas aparecem como um capítulo de relações públicas, sendo ele estudado tanto em uma como em outra disciplina." (1963, p.22).

A idéia, segundo Chaves, é esclarecer que os funcionários deveriam receber um treinamento específico, incluindo conhecimentos básicos sobre a organização - quais serviços presta ou produtos que produz, quais são os seus públicos e o que estes desejam. Na verdade, é ensinar ao funcionário como agir de maneira correta, segundo os preceitos da organização, num treinamento que competiria à área de relações humanas.

As relações públicas contribuiriam com este objetivo de envolver os funcionários em questões da organização, por meio de ações de outra natureza: “(...) o treinamento do 
pessoal em relações com o público faz apenas com que os empregados saibam como agir certo. Não faz com que eles queiram agir certo, que é um outro trabalho, bastante importante, de relações públicas internas (...).” (CHAVES, 1963, p. 23, grifos do autor). Estas informações também são pistas para o entendimento das raízes históricas do que se compreende hoje como “comunicação interna”, campo de estudo específico da comunicação organizacional.

Uma ressalva deve ser feita em meio aos fatos destes momentos decisivos. Certamente, desde as primeiras tentativas de demarcação das relações públicas brasileiras até hoje, não podemos negar que nestes últimos cinqüenta anos os campos profissional e acadêmico desta atividade têm apresentado outras faces, mesmo que mais tímidas e isoladas, em busca do reconhecimento de uma atuação mais afastada de seu conceito como ferramenta gerencial que contribui para os resultados administrativos das organizações.

No entanto, prevalece, a nosso ver como pensamento hegemônico, a vertente conceitual das relações públicas que considera tal atividade como a gestora dos relacionamentos entre a organização e seus públicos de interesse, por meio da comunicação, cujo propósito é o de contribuir essencialmente para a eficácia e a eficiência organizacionais. Esta forma de pensar as relações públicas tem sido a mais destacada nos estudos sobre comunicação organizacional, influenciando fortemente na formação deste campo científico.

A aproximação entre as orientações teóricas de relações públicas e de comunicação organizacional é tão grande no Brasil que muitas pessoas compreendem os significados de ambas as terminologias como sinônimas, o que pode ser um equívoco caso se coloque as duas áreas como campos científicos específicos de saberes autônomos. Como hipótese, pode-se pensar que isso ocorre porque elas, atualmente, são concebidas essencialmente por sua função estratégica, isto é, estão voltadas a contribuir para os resultados das organizações.

\subsection{O discurso hegemônico da comunicação organizacional}

A forma de expressar a sistematização do conceito de comunicação organizacional por autores significativos deste campo de estudos nem sempre é a mesma. A título de exemplificação, indicamos dois autores e seus entendimentos. A estudiosa Margarida Maria Krohling Kunsch (2003b) define comunicação organizacional como "a disciplina que estuda 
como se processa o fenômeno comunicacional dentro das organizações no âmbito da sociedade global. Ela analisa o sistema, o funcionamento e o processo de comunicação entre organização e seus diversos públicos. (...) Fenômeno inerente aos agrupamentos de pessoas que integram uma organização ou a ela se ligam, a comunicação organizacional configura as diferentes modalidades comunicacionais que permeiam sua atividade. Compreende dessa forma, a comunicação institucional, a comunicação mercadológica, a comunicação interna e a comunicação administrativa.” (p.149). Já o pesquisador Paulo Nassar (2008a) entende o significado de comunicação organizacional como "um metassistema social e tecnológico - que tem como objetivo de estudo os processos comunicacionais, no âmbito das empresas e das instituições, suas redes de relacionamento e sociedade -, definido dinamicamente a partir de suas inter-relações com os conhecimentos e as práticas das Ciências Sociais, das Ciências Humanas, das Ciências Exatas e das Ciências Biológicas.” (p.73).

Em contrapartida, é possível notar, a partir da leitura crítica das obras destes estudiosos, que certos aspectos se repetem em suas concepções sobre a área, formando um discurso que se poderia dizer preponderante na atualidade.

Com o propósito principal de compreender esta configuração, optou-se, aqui, pela tentativa de investigação dos traços comuns de determinados expoentes da área que podem sugerir a representação do pensamento hegemônico brasileiro da comunicação organizacional.

A escolha dos estudiosos Francisco Gaudêncio Torquato do Rego, Margarida Maria Krohling Kunsch, Wilson da Costa Bueno e Paulo Nassar deve-se, especialmente, à suas produções bibliográficas e a inserção de cada um no campo acadêmico. Todos eles publicaram obras que são referências nos cursos de graduação na área de comunicação social, especialmente em relações públicas, e, também, nos cursos de lato sensu e stricto sensu de diversas faculdades e universidades brasileiras quando o tema estudado é comunicação organizacional $^{13}$. Os quatro, também, são professores universitários com titulações bem reconhecidas no meio acadêmico ${ }^{14}$. Quanto à abordagem de cada um deles, convém uma ressalva. Como o objetivo deste subcapítulo é apenas apontar a regularidade de certos traços nestes que consideramos representantes do pensamento hegemônico da comunicação

\footnotetext{
${ }^{13}$ Cf. Torquato (1984; 1986; 2004); Kunsch (1997; 2003b); Bueno (2003; 2007); Nassar (2001; 2006d; 2008a); deste último, em co-autoria o livro: Nassar; Figueiredo (1995).

${ }^{14}$ Francisco Gaudêncio Torquato do Rego e Margarida Maria Krohling Kunsch são professores titulares e livredocentes da Escola de Comunicações e Artes da Universidade de São Paulo; Paulo Nassar é professor doutor da mesma instituição e Wilson Bueno da Costa, além de também ser professor da ECA-USP, leciona no programa de pós-graduação em Comunicação Social da Universidade Metodista de São Paulo (UMESP).
} 
organizacional no Brasil, não exploraremos exaustivamente o que cada um tem a dizer sobre cada ponto investigado. Ora um será mais explorado, ora outro. Isso não significa que eles não apresentem pontos teóricos que os diferenciem. Aqui, como veremos à frente, o mais importante é deixar clara a marca de regularidade que permeia estes quatro estudiosos da área e quais são estes traços comuns.

Antes de mais nada, deve-se atentar para o fato de que a terminologia "comunicação organizacional”, neste trabalho, deve ser compreendida como sinônimo de "comunicação empresarial”. Não existe um consenso entre estes quatro autores sobre a utilização de uma mesma terminologia para referirem-se ao tema sobre a comunicação nas organizações. Margarida Kunsch e Gaudêncio Torquato preferem empregar o termo "comunicação organizacional", pois acreditam que o adjetivo "empresarial" limita o entendimento da abrangência e alcance da área. Compreendem que a utilização do adjetivo "organizacional" indica que os estudos deste campo de conhecimento integram a comunicação em qualquer tipo de organização, seja ela privada ou não. O estudioso Paulo Nassar ora referese à "comunicação empresarial", ora à "comunicação organizacional", como sinônimos. Enquanto Wilson da Costa Bueno prefere, mesmo, o termo "comunicação empresarial".

Quatro são os traços comuns investigados, dentre estes autores e suas obras, com o propósito de retratar o pensamento brasileiro preeminente sobre comunicação organizacional na contemporaneidade: 1) a comunicação como parte intrínseca ao processo de gestão organizacional; 2) a comunicação pautada por sua contribuição direta à eficácia e eficiência dos negócios das organizações; 3) a apologia do discurso da "comunicação integrada"; 4) enfoque nas práticas profissionais para discorrer sobre o conceito de comunicação organizacional.

Iniciaremos com a percepção de que a comunicação é inerente ao processo administrativo das organizações, ou seja, ao seu processo de gestão. Há um certo consenso entre os estudiosos pesquisados que a comunicação deve ser considerada um elemento essencial ao bom funcionamento de qualquer organização, ou seja, como mais um recurso que pode auxiliar no controle da estabilidade e desenvolvimento organizacionais. Neste sentido, Torquato (1986, p.16) ressalta:

"Em primeiro lugar, cabe lembrar que a organização persegue seu equilíbrio entre as partes que a formam. Seu equilíbrio é resultante da disposição ordenada entre as partes. Essa integração é obtida graças ao processo 
comunicacional. Aparece, assim, a primeira relação entre comunicação e empresa."

Observa-se que o processo comunicacional é tratado como uma peça da engrenagem administrativa que auxilia a organização a estar em atividade contínua:

"A Comunicação deve ter foco, deve atentar para as questões mais relevantes, para a solução de problemas (pessoais, grupais ou da organização como um todo), deve ser, portanto, estratégica, umbilicalmente associada ao processo global de gestão." (BUENO, 2007, p.94).

Esta idéia que recai sobre a funcionalidade da comunicação nas organizações explica a importância que os nossos autores pesquisados concedem à instrumentalização deste processo relacional. $\mathrm{O}$ foco na transmissão de mensagens ainda ganha papel de destaque no momento em que grande atenção é dada aos instrumentos/ferramentas de comunicação e aos fluxos (descendente, ascendente, horizontal), redes (formal e informal), níveis (intrapessoal, interpessoal) e às barreiras/ruídos do processo comunicativo, como se fosse preciso esmiuçálos para entendê-los racionalmente e, então, poder ter um controle maior sobre ele. A comunicação, nesse sentido, é instrumentalizada com o propósito de colaborar para os bons resultados do processo produtivo.

Esta escolha de como compreender a comunicação nas organizações demonstra uma aproximação deste campo de conhecimento com a administração organizacional ou como melhor conhecemos, hoje, com a gestão organizacional. Ou seja, administrar o processo comunicacional por meio de técnicas e instrumentos que possibilitem transmitir a informação desejada aos receptores escolhidos e, também, receber destes uma resposta quanto ao seu entendimento da mensagem emitida.

Os receptores no processo comunicativo das organizações ainda são tratados por estes autores, no geral, como uma audiência que deve ser atingida por meios bem elaborados tecnicamente e supostamente eficazes de transmissão de mensagens. Assim, observa-se o grande valor atribuído aos veículos de comunicação como elementos centrais no processo comunicacional. Em suma, características da perspectiva instrumental da comunicação são muito bem representadas na percepção da comunicação como parte intrínseca ao processo de gestão organizacional: 
"A comunicação empresarial moderna e excelente tem entre seus principais atributos: o monitoramento dos ambientes nos quais a empresa se insere, para detectar as ameaças e as oportunidades simbólicas; a seleção de informações importantes para tomada de decisão da gestão; o mapeamento dos públicos estratégicos; a velocidade nas emissões e respostas; a formatação impecável e adequada de mensagens; a seleção de mídias adequadas que cheguem aos públicos estratégicos; a habilitação, em comunicação, de todas as pessoas da organização; as pesquisas; o planejamento e a operação de orçamentos." (NASSAR, 2006d, p.122).

Todos estes atributos demonstram a tentativa de caracterizar a comunicação como ferramenta da eficácia e eficiência ao desenvolvimento organizacional. Sob esta égide, o processo comunicacional precisa ser planejado para contribuir com os objetivos da organização. Pois, como afirma Kunsch (2003b, p.180), ao falar sobre comunicação organizacional: “(...) Trata-se de uma gestão coordenada e sinérgica dos esforços humanos e organizacionais com vistas na eficácia”.

Notem-se duas coisas: o verbo "planejar" e o adjetivo "estratégico" foram incorporados ao discurso dos nossos autores pesquisados em suas principais obras que tratam sobre comunicação organizacional. Suas utilizações contribuem para tipificar a comunicação nos moldes da gestão administrativa em prol da eficácia e da eficiência organizacionais:

"Nossa proposta, aqui, é aproveitar os conceitos já produzidos sobre a metodologia de elaboração e implementação do planejamento estratégico nas organizações e aplicá-los, na medida do possível, para formatar um plano estratégico de comunicação organizacional.” (KUNSCH, 2003b, p.247).

O propósito principal é racionalizar o processo comunicacional ao se tentar planejá-lo e, consequentemente, administrá-lo. Neste sentido, os estudiosos escolhidos para uma possível compreensão dos traços que compõe o discurso hegemônico brasileiro sobre a comunicação organizacional incorporam aspectos do próprio discurso dos modelos de gestão empresarial. "Planejamento estratégico da comunicação organizacional”, "estratégias de comunicação nas organizações", "comunicação organizacional estratégica” são alguns dos termos frequentemente utilizados para a caracterização do processo comunicativo nas organizações por Francisco Gaudêncio Torquato do Rego, Margarida Maria Krohling Kunsch, Wilson da Costa Bueno e Paulo Nassar, nos livros pesquisados. A comunicação, diante disso, é 
apresentada como algo que precisa ter alguma finalidade que contribua para as organizações alcançarem seus objetivos.

A difusão da idéia de "comunicação integrada" também exemplifica o aspecto de pragmatismo que é outorgado ao processo comunicacional nas organizações. A adjetivação "integrada" demonstra que tal processo é compreendido como possível de ser dividido, pois não seria necessário "integrar" algo que por si só fosse concebido como único e completo. E, de fato, há um consenso entre os estudiosos escolhidos que a comunicação organizacional compreende diversas modalidades, apesar de nem todos, necessariamente, concordarem com a determinação das mesmas modalidades que comportam a "comunicação integrada".

Kunsch (2003b), por exemplo, acredita na composição de quatro modalidades: comunicação interna, comunicação administrativa, comunicação mercadológica e comunicação institucional, as quais admitem atividades, estratégias, instrumentos e aplicações diferenciadas para públicos-alvo também diversos. Mas a idéia principal é que todas estas modalidades possam ser trabalhadas em sinergia para que a organização tenha uma mesma orientação comunicacional:

"Nosso intuito sempre tem sido demonstrar que a comunicação integrada precisa ser entendida como uma filosofia capaz de nortear e orientar toda a comunicação que é gerada na organização, como um fator estratégico para o desenvolvimento organizacional na sociedade globalizada (...)."(KUNSCH, 2003b, p.179).

Os demais autores destacam outras modalidades em suas obras, não necessariamente de acordo com a tipologia apresentada por Kunsch $(2003 b)^{15}$. No entanto, o que mais nos interessa, aqui, é destacar este aspecto funcional que se aplica à comunicação quando há a tentativa de tipificá-la em modalidades e, também, de criar uma outra roupagem ao processo comunicacional nas organizações quando a idéia é conceber uma associação comum entre tais modalidades que resulte na chamada "comunicação integrada".

O discurso da comunicação integrada é respaldado pelo teor estratégico que se aplica à comunicação organizacional, apresentando como fundamento principal a idéia de que as modalidades comunicacionais precisam interagir e apresentar uma sinergia em prol daquilo que a organização pretende alcançar para seu desenvolvimento:

${ }^{15}$ Bueno (2003), por exemplo, entende que não existe uma distinção entre comunicação administrativa e comunicação interna. 
"A Comunicação Empresarial encerra, agora, um conjunto de novos atributos que a tipificaram como insumo estratégico. Fundamentalmente, caminha para assumir por inteiro a perspectiva da chamada comunicação integrada, com uma articulação estreita entre os vários departamentos, áreas e profissionais que exercem a atividade de comunicação nas empresas ou entidades. Com isso, as vertentes: institucional e mercadológica deixam de ser percebidas como distintas porque estão umbilicalmente associadas ao negócio, à visão e à missão da organização.” (BUENO, 2003, p.8).

Tal afirmação de Bueno (2003) também indica um quarto traço comum entre os autores pesquisados: o campo profissional fundamentando o campo científico. É comum encontrarmos nas obras destes estudiosos o enfoque nas práticas profissionais para discorrer sobre o conceito de comunicação organizacional. Sob o nosso olhar fica a impressão de que o campo científico da comunicação organizacional é pautado, em grande parte, pelo campo profissional. Uma visão, que entre outras coisas, intensifica a compreensão de comunicação organizacional como prática de gestão.

Esta constatação torna-se mais evidente quando examinamos as obras escolhidas e percebemos claramente que seus autores destacam que a concepção sobre comunicação organizacional no Brasil deve-se ao aprimoramento das práticas profissionais de comunicação em organizações. Bueno (2003, p.3) explicita muito bem este ponto quando diz:

"A Comunicação Empresarial, enquanto conceito abrangente, tem menos de 25 anos no Brasil. Na década de 1970, as empresas e associações, evidentemente, já se comunicavam: muitas delas editavam house-organs de prestígio; a publicidade brasileira, embora não tivesse, talvez, a expressão e o reconhecimento internacional de que desfruta nos dias atuais, era, como sempre foi, criativa; e havia trabalhos competentes de relacionamento com a mídia. Mas seria prematuro imaginar que se tivesse verdadeiramente uma Comunicação Empresarial, no sentido amplo com que é conceituada hoje em dia."

Nossos autores buscam demonstrar a importância das práticas profissionais de jornalismo empresarial e de relações públicas como alicerces para o delineamento do campo científico da comunicação organizacional no Brasil. Não raramente, encontramos em seus textos apontamentos que buscam reconstituir historicamente a formação da área de conhecimento em questão por meio de acontecimentos ocorridos nas empresas e que, na visão 
destes autores, são fatos marcantes para a constituição do campo teórico da comunicação organizacional no país. Os surgimentos de novos departamentos de relações públicas em grandes empresas existentes no país, especialmente nas décadas de 1960 e 1970, bem como o aprimoramento das publicações empresariais, por exemplo, são fatos discutidos como fundamentais para a formação da área pelos estudiosos abarcados neste capítulo.

Outro exemplo recorrente nas obras dos autores estudados e que demonstra a influência das práticas profissionais na constituição do campo teórico refere-se à experiência desenvolvida na Rhodia, em meados da década de 1980. Um grupo de profissionais de comunicação da empresa na época, gerenciada por Walter Nori, instituiu o "Plano de Comunicação Social” na tentativa de realizar ações de comunicação de forma estratégica a fim de dar maior visibilidade à Rhodia na sociedade. Esta atitude é tida como inovadora na época e Kunsch (2006) relata sobre este acontecimento como um feito de grande importância para a área: "esse fato constitui um marco de certo destaque na história da comunicação organizacional no Brasil, tendo servido de paradigma para outras organizações que perceberam que precisavam redimensionar sua comunicação para uma perspectiva mais próativa e democrática." (KUNSCH, 2006, p.174).

Os estudos de comunicação organizacional nas universidades, nesta mesma época, parecem ter sofrido ainda mais influência dos acontecimentos do mercado profissional, como nos dá a entender Torquato quando afirma que "o ingresso dos jornalistas nas empresas deu novo ritmo à comunicação organizacional e as universidades foram obrigadas a reforçar o conceito, dando vazão a cursos específicos.” (2004, p.5).

Também é possível constatarmos nas obras consultadas certo mérito dado às associações representativas de profissionais de mercado e de empresas quanto à constituição da área no país. A ABERJE aparece como a associação mais citada pelos autores, neste sentido. Tanto nas obras de Kunsch (1997; 2003b; 2006), de Torquato (1984; 2004) e de Nassar (2001; 2006c; 2007; 2008a) o que se nota é a enunciação de que o surgimento e o fortalecimento da ABERJE influenciam a formação da própria comunicação organizacional no Brasil. $\mathrm{O}$ professor e pesquisador Paulo Nassar tem sido, ao que parece, o estudioso mais interessado em confirmar esta constatação:

"O reconhecimento do papel da Aberje como protagonista da fundação e do desenvolvimento do campo profissional e teórico da Comunicação Organizacional no Brasil é encontrado em Kunsch (1997, p.57-61), que, com 
base em fontes documentais e depoimentos, demonstra ser a Aberje o "embrião da Comunicação Organizacional brasileira”. Torquato (1984, 1998, 2002) também destaca o papel pioneiro da Aberje, principalmente aquele voltado a profissionalizar as publicações empresariais.” (2007, p.33).

Deste modo, enxergarmos algumas pistas que nos levam à hipótese que o campo científico da comunicação organizacional tem sido, ao longo de sua formação, pautado pelas práticas profissionais.

Os quatro traços identificados anteriormente indicam o pensamento hegemônico brasileiro sobre comunicação organizacional na contemporaneidade. E trazem à tona que a dimensão estratégica é a grande norteadora desta corrente de estudos. $\mathrm{O}$ aspecto estratégico impresso à comunicação reforça a característica de aplicabilidade profissional da área e dificulta, de certa maneira, que esta reflita sobre o processo comunicacional nas organizações de outras maneiras que não aquelas ligadas à gestão organizacional.

\subsection{As teorias da comunicação na formação do campo da comunicação organizacional}

Certamente, qualquer área de conhecimento científico ou acadêmico busca desenvolver fundamentos para sustentação de suas pesquisas e seus estudos. Algumas áreas conseguem gerar conhecimento a partir da análise dos fenômenos próprios a ela, como é o caso da sociologia, por exemplo, já outras têm dificuldades em conseguir alcançar a condição de produtoras de um saber autônomo, tendo que, deste modo, buscar auxílio nas teorias de outras disciplinas.

A partir do momento que uma área apresenta dificuldades em produzir conhecimento próprio, ou seja, original, o aceite da inserção de pesquisadores de outras áreas trazendo consigo, teorias e métodos de análise próprios de disciplinas que analisam fenômenos que nem sempre são pertinentes à área hospedeira - acaba sendo encarado como algo natural e, até mesmo, necessário.

Martino (2007) nos faz refletir sobre esta problemática como concernente à área da comunicação ao distinguir teorias da comunicação de teorias sobre comunicação (grifo do 
próprio autor). Indaga que para uma área ser considerada disciplina deve ser produtora de uma saber autônomo, concebendo conhecimento próprio, originado fundamentalmente de análises de fenômenos comunicacionais, isto é, teorias da comunicação. Por outro lado, este autor expõe que o mais observado são as teorias sobre comunicação, oriundas de aportes das disciplinas como psicologia, ciências políticas, dentre outras.

Esta não é uma discussão tranqüila de ser travada em nosso meio acadêmico, especialmente porque a área da comunicação, no sentido mais amplo, tem sido caracterizada pela interdisciplinaridade. Não podemos negar que o diálogo com outras áreas de conhecimento apresenta-se bastante interessante e rico nos estudos em comunicação. Mas, é comum observamos uma excessiva e, muitas vezes indevida, apropriação de teorias e métodos de outras áreas para o tratamento de objetos de pesquisa relacionados à comunicação. A própria área da comunicação organizacional pode-se dizer frágil quanto a esta situação.

O saber comunicacional dos estudos atuais que compõem a área da comunicação organizacional parece perder espaço para outras disciplinas. Cada vez mais se observam conhecimentos relacionados a disciplinas, caso da administração, nos estudos da área do que propriamente discussões relativas ao fenômeno comunicacional ${ }^{16}$.

É comum nos depararmos com estudiosos de outras áreas buscando uma inserção na área da comunicação organizacional. Engenharia, Administração, Lingüística, Psicologia são alguns exemplos destas áreas. Obviamente que estes estudiosos têm amplo direito em desenvolver suas pesquisas na área da comunicação e, inclusive, em comunicação organizacional. Afinal, seria inaceitável qualquer tipo de censura na produção científica. Porém, dois pontos são importantes de serem levados em conta. Primeiramente, é indispensável respeitar a "centralidade do fenômeno comunicacional" (MARTINO, 2007, p.28), ou seja, os pesquisadores devem se utilizar da comunicação para explicar os propósitos de seus estudos e não o contrário. Segundo, estes estudiosos precisam, portanto, esforçar-se por adquirir conhecimento aprofundado das teorias da comunicação para, então, desenvolver suas pesquisas no campo da comunicação organizacional.

Ressalta-se que a interdisciplinaridade não é vista aqui como algo negativo no campo da comunicação organizacional - pelo contrário -, no entanto, é preciso atenção para que a centralidade dos estudos esteja realmente atrelada às teorias da comunicação. Nós

\footnotetext{
${ }^{16}$ Isto, embora seja uma constatação empírica de nossa parte, tem sido perceptível nos trabalhos científicos apresentados em eventos científicos - congressos e seminários - sobre comunicação organizacional.
} 
mesmos, nesta dissertação, procuramos dialogar com as teorias da sociologia do trabalho para pensar sobre a comunicação interna, entretanto, isso não significa que esta dissertação esteja prioritariamente no campo de estudo da sociologia do trabalho. Deve ser considerado um estudo de comunicação a partir do momento que sua centralidade está em analisar vozes representativas da área da comunicação organizacional - mais especificamente os aspectos da comunicação interna - com o auxílio, sim, de teorias da sociologia do trabalho, que são importantes nas reflexões a respeito da comunicação interna, mas também por meio de interpretações sobre como a área em questão tem compreendido os processos comunicativos no seu contexto teórico.

Sob esta luz, pretendemos trazer à tona reflexões com base em determinadas perspectivas de comunicação que possam contribuir para se pensar a comunicação organizacional, e consequentemente, a comunicação interna. Nossa discussão gira em torno de duas questões: haveria forte receptividade da área de comunicação organizacional com as correntes de pensamento baseadas no modelo informacional? As escolhas desta área configuram um campo de estudos que dialoga com abordagens atuais da comunicação? Buscar respostas para estes questionamentos pode ser o esforço no estabelecimento, mesmo que parciais, de uma fundamentação mais crítica e pertinente à área da comunicação organizacional, possibilitando que não seja reconhecida sobretudo como um campo constituído pelas práticas profissionais e sua dimensão estratégica.

Comunicação e informação são termos que para muitos, ainda hoje, não apresentam significados claros. Não me refiro à utilização destas palavras no senso comum como, por exemplo, quando alguém fala "preciso comunicar algo a você". Pois, certamente utilizamos a palavra "comunicar" para exprimir o significado de "informar" corriqueiramente no nosso dia-a-dia e seremos compreendidos sem muitas dificuldades. Por outro lado, compreender a comunicação prioritariamente como transferência de mensagens, nos estudos teóricos de comunicação mais recentes, apresenta-se como um grave problema conceitual.

A idéia em compreender a comunicação como um mecanismo de transmissão de informações é uma herança dos velhos tempos, mas que ainda permeia as abordagens conceituais de vários estudiosos atualmente, inclusive da área da comunicação organizacional. 
Isso não significa necessariamente a negação que estão surgindo, ou possam surgir, novos estudos com abordagens renovadoras ${ }^{17}$ em comunicação organizacional.

Com o auxílio de uma breve retomada da história das teorias da comunicação é possível relembrarmos alguns estudos que constituíram este modelo comunicativo de grande receptividade no século XX. Lembremos do conjunto de estudos norte-americanos intitulado Mass Communication Research, formado e fortalecido hegemonicamente entre os períodos de 1920 e 1960. Diversas abordagens teóricas integraram esta tradição de estudos com contribuições de pesquisadores de áreas distintas como engenharia, psicologia e sociologia, mas com características em comum bem marcantes, dentre as quais se destacam: ênfase no empirismo com a preocupação de quantificar resultados das análises realizadas; orientação pragmática, procurando entender o funcionamento dos processos comunicativos na intenção de melhorar resultados; escolha por objetos de estudo de comunicação mediática em primeiro lugar (ARAÚJO, 2008).

Nota-se que diversos estudos de comunicação organizacional no Brasil são marcados por estes atributos ainda hoje. Pesquisas são desenvolvidas com o interesse de alcançar respostas a problemas que por algum motivo impedem o funcionamento da comunicação em contribuir para a eficácia e eficiência organizacionais. A questão quantitativa da comunicação, neste sentido, tem sido uma das preocupações de muitos estudiosos, sendo a mensuração de resultados de planos e estratégias de comunicação um ponto perseguido pelos estudos de comunicação organizacional ${ }^{18}$.

As características da escola norte-americana indicadas por Araújo (2008) estão incorporadas em algumas correntes de pensamento que construíram este campo de estudos. Uma delas é o conhecido "paradigma de Shannon \& Weaver", o qual retrata a comunicação exatamente como algo que se constitui através do envio de informações de um ponto a outro, desconsiderando os elementos simbólicos em jogo. Sob este ponto de vista, o que interessa é a condução da mensagem ao destinatário com o mínimo de interferência possível, ou seja, com nenhum ruído por meio de canais apropriados. A comunicação será realizada se os canais utilizados para a transferência da mensagem forem os mais adequados.

\footnotetext{
${ }^{17}$ A tese de doutorado de Germano Augusto Azambuja (2003), por exemplo, traz discussões interessantes para se repensar as teorias da comunicação no campo da comunicação organizacional.

${ }^{18}$ A título de exemplificação destaca-se o número 2 do periódico Organicom: Revista Brasileira de Comunicação Organizacional e Relações Públicas, produzido com o fito de, especificamente, tratar sobre "avaliação e mensuração em comunicação organizacional”, como o próprio título do dossiê da revista revela.
} 
Esta perspectiva, surgida em meados da década de 1940, relaciona-se à temática da cibernética que se preocupa prioritariamente, senão exclusivamente, com problemas práticos que envolvem a emissão de sinais entre máquinas, dentre outras questões de ordem formal. $\mathrm{O}$ nível técnico é considerado, deste modo, o maior problema da comunicação. Busca-se encontrar meios para controlar o envio de informações ao destinatário evitando-se ruídos. $\mathrm{O}$ conteúdo não é levado em consideração nesta perspectiva, sendo a atenção voltada a "como transmitir a máxima quantidade de informação no menor tempo possível e com a máxima fidelidade, valendo-se para tanto de conceitos físicos e matemáticos, do que se convencionou chamar de "Teoria da Informação." (RÜDIGER, 1998, p.20).

Sob esta égide, existe a expectativa de que as mensagens serão recebidas pelo destinatário da mesma forma que o emissor determinou, sem interrupções ou ruídos no caminho. É perceptível, neste caso, a preocupação com a quantidade, a rapidez e os fluxos da informação. O caminho que leva a informação da fonte ao destinatário é o elemento central do fenômeno comunicativo, sendo, por assim dizer, este considerado um processo linear. A “Teoria da Informação”, também conhecida como a "Teoria Matemática da Comunicação”, não se interessava pelo aspecto social da comunicação.

Não será surpreendente de nossa parte se constatarmos a aproximação da comunicação organizacional com alguns destes conceitos. Por meio de uma leitura cuidadosa das obras de autores brasileiros desta área, observa-se a forte preocupação com o mecanismo de transferência de mensagens. Ainda hoje a discussão é permeada por questões como redes, fluxos, barreiras e ruídos de comunicação, bem como em produção de mensagens, em seleção de canais e na atitude do emissor. Afirmamos isso com base em referências bibliográficas produzidas tempos atrás, mas que continuam sendo utilizadas e citadas por estudiosos representativos da área, como também com o apoio de textos e obras produzidas recentemente.

Para exemplificar tal constatação, destacamos o estudioso Torquato (1986, p.33) que afirma: "A grande quantidade de comunicação instrumental, no fluxo descendente, inibe e bloqueia os caudais da comunicação expressiva, que, por falta de vazão para subirem até o topo, correm lateralmente, criando redes informais de comunicação. Estas redes absorvem grandes quantidades de mensagens ambientais (principalmente em momento de crise) constituindo verdadeiros focos de tensão e alterando os comportamentos normativos.” É muito comum a utilização dos conceitos de "rede formal" e "rede informal", pelos estudiosos 
de comunicação organizacional, para caracterizar a comunicação oriunda da estrutura organizacional e da comunicação proveniente das relações sociais entre as pessoas de forma espontânea, respectivamente. Já os fluxos comunicativos, também bastante citados não somente por Torquato $(1986,2004)$, mas também pelos estudiosos Kunsch (2003b) e Nassar (2008a), são caracterizados como fluxos: descendente ou vertical, ascendente, horizontal ou lateral, transversal ou longitudinal e o circular. Estas designações são utilizadas para demonstrar as possibilidades de direção da mensagem no processo de transferência do emissor ao receptor.

Não existe, aqui, a intenção em equiparar os conceitos elaborados pelas correntes de pensamento da "Teoria da Informação" com as concepções de comunicação dos autores de comunicação organizacional. Certamente os atuais conceitos concebidos pela área de comunicação organizacional não tomam para si todas as idéias deste paradigma. Por outro lado, não podemos negar que a influência do modelo informacional ainda, nos dias de hoje, é determinante no entendimento de comunicação proposto por autores representativos da área. Note-se, por exemplo, o seguinte entendimento de Torquato (2004):

\footnotetext{
"O insucesso do ato comunicativo deriva, portanto, do primeiro elo da equação da comunicação - a Fonte. Lembremos o modelo clássico da comunicação: $F+M+C+R$. Fontes $(F)$ transmitem Mensagens $(M)$, por meio de Canais $(\mathrm{C})$, para Receptores (R). Como a comunicação é um processo que envolve, integradamente, cada um dos componentes acima listados, a eficácia do ato comunicativo, em sua globalidade, dependerá da eficácia do comportamento das partes que o compõem. Há de se averiguar, desse modo, cada componente do sistema de comunicação a fim de se distinguir os níveis de ruído. Parcela ponderável dos problemas de comunicação organizacional situa-se, por exemplo, nas esferas da fonte e não no âmbito dos canais ou das linguagens, como costumeiramente se considera." (p.36).
}

Os aportes do paradigma informacional que norteou as pesquisas por muito tempo, e que ainda está presente em alguns estudos de nossa área, aproximam-se claramente da perspectiva instrumental dos processos comunicativos, mais conhecida como "paradigma funcionalista" em que o ato de comunicar objetiva dominar o comportamento daquele que recebe a informação. O emissor, neste contexto, é quem dirige o processo comunicativo, é aquele que tem controle não somente da informação, mas, também, da conduta do receptor. 
Tem sido atribuído a Harold Lasswell o mérito por estabelecer as bases do paradigma funcionalista da comunicação, na mesma época em que os fundamentos da teoria da informação ganharam acolhimento de muitos estudiosos. Conforme este modelo, também conhecido como "seringa hipodérmica", o processo comunicativo configura-se pela necessidade de pessoas influenciarem outras pessoas por meio de transferência de mensagens. A intenção seria de conseguir o efeito esperado no comportamento do receptor que recebeu as mensagens mais apropriadas e de forma correta. O emissor, neste contexto, é a figura principal, responsável pelo êxito do processo comunicativo.

O modelo funcionalista da comunicação está baseado na teoria sociológica "estrutural-funcionalismo", a qual entende o sistema social como um organismo que se divide em partes com determinadas atribuições para manter o todo funcionando ${ }^{19}$. Sob esta ótica, o paradigma funcionalista da comunicação sustenta o argumento de que as pessoas se comunicam para cumprir determinadas funções que contribuem para a conservação do sistema social. Parafraseando Lasswell, Rüdiger (1998, p.50) destaca três destas funções: “a primeira é a generalização do conhecimento comum ou supervisão do contexto social”, “a segunda é o correlacionamento das respostas dadas pelos sujeitos aos problemas colocados pelo sistema social" e "a terceira função é a transmissão do patrimônio cultural da sociedade", ajudando na coesão do sistema social ao reforçar o cumprimento dos papéis sociais. Admitese, dentro deste paradigma, que possam existir certo momentos de falta de coesão entre as pessoas e a sociedade, estes compreendidos como exceções. Os boatos e rumores dentro de uma organização, por exemplo, seriam conseqüências desta falta de coesão existente esporadicamente. O funcionalismo, em síntese, atribui à comunicação a função de manter os padrões previamente estabelecidos em prol da ordem social:

"A comunicação constitui, portanto, um processo que visa, em essência, minimizar as tensões e reduzir a complexidade dos problemas da interação social; que, embora por vezes veicule certas disfunções, visa em última instância conter as tendências à desintegração do sistema societário.” (RÜDIGER, 1998, p.51).

\footnotetext{
${ }^{19}$ Esta concepção nos faz lembrar da idéia de "comunicação integrada”, cujo significado é divisão da comunicação organizacional em modelos comunicacionais: comunicação interna, comunicação administrativa, comunicação mercadológica e comunicação institucional, sendo que cada um deles deve contribuir para o bom funcionamento da comunicação com um todo.
} 
Não por acaso, o campo da comunicação organizacional concebe o processo comunicativo como um fator que facilita e até mesmo possibilita a ordem organizacional. Seja como processo ou como técnica, é entendida como a engrenagem que "intermedia $[s i c]$ o discurso organizacional, ajusta interesses, controla os participantes internos e externos, promove, enfim, maior aceitabilidade da ideologia empresarial." (TORQUATO, 1986, p.17).

O modelo funcionalista, ao longo do tempo, passou por modificações quanto ao entendimento do emissor e do receptor no processo comunicativo. Após pesquisas empíricas, notou-se que o receptor não age necessariamente conforme a maneira que o emissor determina. A relação entre emissor e receptor não é unidirecional. Constata-se, portanto, que o receptor precisa entender o conteúdo da mensagem para que o processo comunicativo se realize. Além disso, observou-se que o conteúdo das mensagens por si só não modificam os comportamentos dos receptores. Os contextos sociais são determinantes na maneira como as pessoas se comunicam.

Tendo em vista estas modificações, ganha destaque a teoria conhecida como "two step flow" ou "fluxo em duas etapas". Entende-se, a partir deste pensamento, que as mensagens, antes de serem recebidas pelo destinatário, passam por uma espécie de seleção dos grupos sociais com os quais este se relaciona. Os formadores de opinião destes grupos teriam grande poder de influenciar o entendimento que o receptor pode vir a ter do conteúdo das mensagens enviadas pelo emissor. Desempenhando o papel de porta-vozes das idéias de um grupo de pessoas, os formadores de opinião, na teoria "two step flow", são considerados elemento indispensável para o êxito do processo comunicativo (RÜDIGER, 1998; ARAÚJO, 2008).

Não raramente nos deparamos com aspectos deste modelo comunicativo nos estudos atuais de comunicação organizacional. A figura do "líder organizacional", por exemplo, é defendida como importante para influenciar as pessoas que interagem com a empresa em prol do bom funcionamento da organização ${ }^{20}$.

A partir de meados da década de 1960, o modelo de comunicação tecnocêntrico bem como a concepção de que a comunicação é realizada porque emissor e receptor pretendem influenciar um ao outro - começou a ser questionado fortemente por diversos pesquisadores que se interessavam em estudar o processo comunicativo não mais com a idéia

\footnotetext{
${ }^{20}$ A questão do "líder organizacional" ou das "lideranças" nas organizações é considerada, por exemplo, nas obras de Marlene Marchiori (2006a; 2006b, 2008a, 2008b) e Gaudêncio Torquato (1986; 2004).
} 
central de transmissão de informação, mas, agora, considerando as estruturas sociais e culturais que propiciam a interação entre as pessoas. Começou-se a entender melhor que a comunicação não é mediada exclusivamente pela técnica, apresentando-se como um processo de interação social mediado pelas formas simbólicas. O paradigma anterior, oriundo da “Teoria da Informação”, mostrou-se insuficiente para explicar o processo comunicativo:

"A comunicação, visualizada como processo de transmissão de informações, é concebida como um processo intencional de consecução de resultados, comandado pelo comunicador. As pessoas se comunicam visando a determinados objetivos, com propósito puramente instrumental, por meio de procedimentos técnicos, em que não há lugar para os conceitos de compreensão, sentido e interpretação, não há lugar para o entendimento dos processos comunicativos como fontes de conhecimento. O modelo em foco enfatiza as estruturas técnicas em detrimento das mediações simbólicas, que não se deixam apanhar com os conceitos de emissão e recepção, nem mesmo com o conceito de código, remetendo antes ao conceito de sentido e aos problemas de sua interpretação." (RÜDIGER, 1998, p.28).

Podemos admitir que comunicar também implica em distribuir informações, porém, isto não deve resumir o seu conceito e nem ser o seu principal elemento constitutivo. O modelo informacional não é mais suficiente para explicar a comunicação. E novas abordagens, interessadas em compreender o processo de recepção, começam a ganhar mais atenção por parte dos estudiosos em comunicação. Araújo (2008) indica com bastante clareza que a partir dos anos 1960 outras perspectivas ganham força nos estudos de comunicação, contrariando aspectos da tradição norte-americana de décadas anteriores. Dentre estas novas perspectivas estão: o Interacionalismo Simbólico, a Semiótica, a Escola de Palo Alto, a Corrente Culturológica francesa, a Semiologia e os Estudos Culturais.

Martín-Barbero tem sido um dos mais notórios pensadores que discute a recepção sob uma ótica que contraria o entendimento de comunicação centrado nos canais e nos meios, ou seja, na transmissão de mensagens. Seus estudos nos fazem repensar o processo de comunicação diferentemente do que ele próprio chama de "epistemologia condutista" (1995, p.41), na qual é o emissor quem comanda a atividade de comunicação e o receptor é considerado como se fosse um depósito de informações ${ }^{21}$ reagindo unicamente por meio de

\footnotetext{
${ }^{21}$ Walter Benjamin, em seu texto “A obra de arte na época de sua reprodutibilidade técnica” já nos alertou que no processo comunicacional o receptor não deve ser considerado como mero depositário de informações. Theodor
} 
estímulos enviados pelo emissor. A recepção, conforme este modelo mecanicista, não pode ser um lugar de produção e negociação de sentido. E é exatamente este um dos pontos questionado pelo estudioso.

A recepção é uma forma de interagir com a sociedade e ela é mediada pelas práticas culturais dos interlocutores do processo comunicativo. O processo comunicativo, portanto, começa ser pensado por meio da cultura ${ }^{22}$, sendo necessário levar em consideração elementos como a "heterogeneidade de temporalidades" e a "mediação das novas fragmentações culturais e sociais." (MARTÍN-BARBERO, 1995, p.44). O primeiro elemento significa que é necessário inserirmos a dimensão histórica no processo de comunicação ao contemplarmos a multiplicidade de experiências históricas de vários lugares (países, regiões) e momentos diferentes, e o segundo elemento revela a necessidade da compreensão do processo comunicativo além da divisão tradicional de sociedades de classes. Pois, hoje, muitos são os tipos de fragmentação social e cultural: jovens, mulheres, homossexuais, etc. No entanto, vale ressaltar que isto não significa que se deve compreender a recepção desconectada das relações de produção. O receptor não aparece como um indivíduo que é manipulado pelas forças

W. Adorno, um dos fundadores da "Escola de Frankfurt", analista do fenômeno que ele denominou de Indústria Cultural, sobretudo de sua lógica puramente mercantil na sociedade, afirmava, ao menos em seu primeiro texto sobre o assunto, escrito em parceria com Horkheimer, que ao receptor não haveria outra condição senão a de passivo numa relação desigual na comunicação de massa (ADORNO; HORKHEIMER, 1985). Benjamin, no entanto, refutou esta concepção de recepção ao considerar que o indivíduo pode sim fruir uma obra de arte, por exemplo, o filme, com crítica e não aceitar totalmente os ideais que são a ele impostos por determinado produto da Indústria Cultural. O massivo, segundo o próprio Martín-Barbero (2003) possui contradições próprias, relações de cotidianidade e formas de viver o simbólico de maneiras distintas do acionado pela Indústria Cultural e formas dominantes de poder. Assim, os processos culturais e, consequentemente comunicacionais, não podem ser compreendidos apenas por uma concepção ideológica de classes sociais, entre dominantes e dominados. A organização social mais geral inclui práticas sociais próprias de cada povo, que faz o indivíduo agir diferentemente nos processos comunicacionais.

${ }^{22}$ Pensar esta concepção de comunicação requer uma reflexão sobre o significado de "cultura”. Raymond Willians, em sua obra intitulada "Cultura" (1992), nos traz algumas pistas. Em primeiro lugar este estudioso afirma que ao tratarmos de "cultura" é preciso situar tal termo e seu significado no âmbito de uma compreensão que extrapola a lógica dual capitalista entre dominantes e dominados. Inseri-los em uma concepção mais ampla da ordem geral significa concordar que as práticas sociais de um povo são essenciais à formação de sua "cultura". Os lugares, o tempo, o modo de vida e os entendimentos de uma organização social mais geral são condições especiais e necessárias para o pensamento sobre cultura. Em segundo lugar, existem alguns critérios sociológicos como sistemas de sinais, formas e tipos que podem auxiliar na análise e nas distinções do que são expressões culturais. Os meios de comunicação de massa, como o rádio e a televisão, podem ser considerados expressões culturais segundo as argumentações de Willians (1992). Apesar da lógica comunicacional, nestes meios, ser comumente reconhecida como prioritariamente mercantil e comercial, isso não significa que não existam práticas comunicacionais resultantes diferentemente das guiadas pelo lucro e que são advindas da própria televisão comercial. O gênero melodrama, por exemplo, pode ser considerado uma expressão cultural em que as classes subalternas identificam-se com suas possibilidades de reconhecimento de apontamentos de suas próprias vidas. Assim, tal manifestação televisiva não está simplesmente cumprindo as funções mercantis da Indústria Cultural, até mesmo porque o receptor não é um depositário de informações sem reação crítica. 
produtivas, mas, também, não se desconsidera que os elementos econômicos possam condicionar o processo comunicativo.

Martín-Barbero (2003), aliás, destaca de forma bastante pertinente o pensamento de Gramsci que defende que nem tudo que é hegemônico, é submissão aos valores dominantes, como também não é simplesmente resistência. Internamente ao hegemônico existem valores e contradições próprias que buscam um reconhecimento como classe, grupo ou movimento.

Pensar a comunicação através da cultura é o que Martín-Barbero (2003) propõe e, para tanto, defende que é necessário deslocarmos o objeto metodológico da análise dos meios para as mediações, ou seja, para as articulações entre as práticas de comunicação e movimentos sociais e para a pluralidade de matrizes culturais. Argumenta que a crise do modernismo e as diferentes formas de se pensar a trama da organização social impulsionaram o redescobrimento do popular na cultura. As práticas culturais começaram a ser analisadas não mais unicamente centradas no eixo dicotômico da ideologia marxista mercantil (dominantes versus dominados), mas, também, considerando-se as práticas sociais dos produtores culturais. Trata-se, assim, de um reconhecimento importante da atuação política e social das classes subalternas. A recepção é fruto das relações sociais do receptor e não somente da ordem econômica. As classes subalternas podem até assimilar as ofertas da indústria cultural, mas o fazem porque não têm escolha. Isso não quer dizer, segundo esta concepção, que não haja crítica alguma.

Pensar a comunicação a partir da cultura exige-se considerar o receptor como um “produtor de significações” (MARTÍN-BARBERO, 2003) e não como um mero decodificador de mensagens enviadas pelo emissor. Os indivíduos têm sua própria maneira de apreender o mundo simbólico através de suas relações de cotidianidade, familiaridade e práticas culturais, com as quais se identificam. E pensar a comunicação neste contexto é considerá-la através da cultura:

"Reconceitualização da cultura que nos confronta com essa outra experiência cultural que é a popular, em sua existência múltipla e ativa não apenas na memória do passado, mas, também, na conflitividade e na criatividade atuais. Pensar os processos de comunicação neste sentido, a partir da cultura, significa deixar de pensá-los a partir das disciplinas e dos meios. Significa romper com a segurança proporcionada pela redução da problemática da comunicação à das tecnologias." (MARTÍN-BARBERO, 2003, p. 297). 
Este pensamento de Martín-Barbero $(1995 ; 2003 ; 2004)$ tem contribuído para uma nova forma de se considerar a comunicação, não mais centrada no modelo funcionalista e mecanicista, mas, entendida no campo das mediações e da produção de sentidos.

A escolha deste caminho para pensar a comunicação organizacional nos parece ser interessante. No entanto, requer um esforço de pesquisadores e estudiosos em rejeitar a perspectiva funcionalista de comunicação e tentar compreender este novo propósito da comunicação. É o que o pensamento de Martín-Barbero sugere:

"É indubitável que o estudo da recepção, no sentido em que estamos discutindo, quer resgatar a vida, a iniciativa, a criatividade dos sujeitos; quer resgatar a complexidade da vida cotidiana, como espaço de produção de sentido; quer resgatar o caráter lúdico da relação com os meios; quer romper com aquele racionalismo que pensa a relação com os meios somente em termos de conhecimento ou de desconhecimento, em termos ideológicos; quer resgatar além do caráter lúdico, o caráter libidinal, desejoso, da relação com os meios." (MARTÍN-BARBERO, 1995, p. 54).

As organizações, de qualquer natureza, estabelecem relações com indivíduos na sociedade devido a diversos motivos, sejam eles econômicos ou não. Relações estas que se configuram por meio de uma negociação constante de interesses que se dá pela comunicação. Existe uma relação de forças na disputa dos interesses de cada parte interessada no processo comunicacional em que alguns momentos "ganha-se" e em outros momentos "perde-se". Nenhuma das partes ganha a disputa sempre.

Esta configuração exige o distanciamento da formulação do pensamento de comunicação organizacional sob o viés que privilegia a dimensão estratégica e atribui centralidade aos canais, meios e instrumentos de comunicação em detrimento do entendimento maior do receptor na contemporaneidade. Compreender o outro - suas percepções de mundo - no processo de interação parece ser a escolha menos anacrônica no cenário atual. Wolton (2006) nos alerta que informar não é mais suficiente para comunicar e que o receptor está se tornando mais crítico quanto à interpretação e aceitação das mensagens que lhe são transmitidas. Não mais existe uma relação direta entre quantidade de informações com o fortalecimento da comunicação e "é todo o esquema informação/comunicação válido do século XVI ao século XX que deve ser revisto." (WOLTON, 2006, p.17). 
Este autor ainda nos lembra que três são os campos que devem ser destacados na análise da comunicação: o técnico, o econômico e o social e cultural. Este último considerado o mais importante por ele, pois "quanto mais as mensagens se globalizam, mais as diferenças culturais da comunicação se afirmam.” (WOLTON, 2006, p.17). Diante deste cenário teórico como se portam os estudos de comunicação organizacional? Nossa hipótese, que de certa forma acreditamos ter alguma validade, é que os estudos em comunicação organizacional estão mais concentrados na dimensão técnica do processo comunicativo. A atenção maior é despendida aos instrumentos e ferramentas de comunicação, deixando de lado, de modo geral, tentativas de se compreender o contexto sociocultural em que está inserido o receptor. Entender este contexto sociocultural é essencial, obviamente com o propósito de uma negociação de interesses e não como tentativa de controle do processo comunicacional - até mesmo por que isto, a nosso ver, seria impossível.

\subsection{Tentativas de repensar a comunicação organizacional}

A interpretação predominante da análise do campo da comunicação organizacional, nesta dissertação, tem revelado até o momento uma grande aproximação desta área com as formas de se pensar a comunicação que privilegiam o processo de transferência de informações. Não por acaso, nos deparamos com obras e textos atuais de estudiosos que norteiam suas reflexões sobre comunicação com base numa discussão sobre fluxos, redes e níveis com o propósito de explicar o processo comunicativo. Esta escolha nos permite questionar se existe, de fato, interesse deste campo de estudos em constituir-se como uma área de produção de saberes que possibilite uma compreensão crítica das relações entre comunicação e organização.

Ainda que sejam trabalhos pouco disseminados, no entanto, observam-se estudos de comunicação organizacional divulgados no Brasil que parecem caminhar em outras direções com o propósito de compreender o processo comunicativo sob uma ótica diferente daquela centrada na transmissão de informação ${ }^{23}$.

\footnotetext{
${ }^{23}$ Cf. Baldissera (2000; 2004); Casali (2006).
} 
Alguns destes estudos têm se baseado nos referenciais teóricos que abarcam os paradigmas sociológicos pensados pelos estudiosos Gibson Burrel e Gareth Morgan na década de 1970. Estes paradigmas foram elaborados inicialmente em contribuição aos estudos sobre organizações e acabaram sendo incorporados nas análises dos processos de comunicação organizacional, especialmente de pesquisadores norte-americanos como Linda L. Putnam e Michael E. Pacanowsky (1983). Segundo o próprio Burrell (1998), em seu texto "Ciência Normal, Paradigmas, Metáforas, Discursos e Genealogias da Análise”, ele e Morgan pensaram em quatro paradigmas sociológicos que poderiam proporcionar a ampliação da visão dos pesquisadores sobre organizações além da dominante perspectiva funcionalista. Em vista da adequação de seus aportes teóricos às pesquisas de comunicação organizacional, a estrutura dos paradigmas sociológicos de Burrell e Morgan tem sido utilizada em estudos de diversos países, inclusive no Brasil.

Estes paradigmas são conhecidos pelas seguintes denominações: funcionalista, interpretativo, estruturalista radical e humanista radical. Integrando as abordagens objetiva e subjetiva das ciências sociais, a idéia é que nenhum deles substitua o outro, mas, possam ser conjugados através das múltiplas visões que proporcionam à análise de possíveis estudos organizacionais. Em linhas gerais, podemos distinguir estes paradigmas da seguinte forma: o funcionalismo enxerga a realidade social de forma objetiva e ordenada; o interpretativo, assim como o funcionalismo, reflete uma preocupação com a ordem social, mas trata a sociedade como algo construído por meio de experiências subjetivas de seus membros; os paradigmas estruturalista radical e humanista radical - conhecidos também como perspectivas críticas assumem o argumento que a sociedade é controlada por forças dominantes e é permeada por conflitos e mudanças contínuas. Estes últimos paradigmas diferem-se entre si na identificação das condições que envolvem a dominação do indivíduo: humanistas radicais preocupam-se mais com as questões subjetivas, considerando que as pessoas vivenciam espécies de "prisões psíquicas" desenvolvidas por meio das realidades opressivamente construídas, enquanto que os estruturalistas radicais conferem mais atenção aos aspectos objetivos, interessam-se pelos aspectos materialistas - por exemplo, as relações de produção - como fontes de dominação da ação individual (PACANOWSKY; PUTNAM, 1983, p.33). 
Nota-se que estes paradigmas sociológicos, no geral, são incorporados de maneira pouco aprofundada ${ }^{24}$ nos estudos brasileiros de comunicação organizacional, atenção maior é conferida aos modelos funcionalista e interpretativo, com a indicação de que a área enxerga a necessidade de distanciar-se do enfoque do primeiro e aproximar-se dos aspectos do segundo nas análises das suas pesquisas atuais.

É possível observar que a obra escrita pelos autores Michael Pacanowsky e Linda L Putnam (1983) tem sido referência central para o entendimento sobre o que se pensa em termos do que a área considera como os paradigmas funcionalista e interpretativo nos estudos em comunicação organizacional no Brasil. Deste modo, cabe destacar aqui certas diferenças entre estes dois paradigmas, sob o ponto de vista destes autores, para compreendermos como tais modelos são incorporados nos estudos brasileiros ${ }^{25}$.

A perspectiva funcionalista considera os fenômenos sociais como fatos materializados e tangíveis, construídos independente da atividade humana. As organizações, deste modo, são entendidas como estruturas fixas, que não sofrem mudanças e são constituídas prioritariamente por padrões, normas e regras. Os processos sociais são reificados para serem apreendidos e tomados como passíveis de análise, desconsiderando as ações dos indivíduos sobre a organização. Os funcionalistas assumem uma visão unitária da organização, já que tratam as organizações como entidades concretas. A organização é analisada como um conjunto de partes que se integram para alcançar interesses e objetivos pré-determinados em que indivíduos se tornam instrumentos de ações propositadamente planejadas para a efetividade tecnológica e eficiência organizacional. Um outro aspecto da visão funcionalista nas pesquisas de comunicação organizacional refere-se à atenção despendida aos processos gerenciais na busca por métodos em prol da eficiência administrativa da organização. Os fenômenos sociais relacionados à organização são analisados sob uma visão quase que estritamente do ponto de vista gerencial. Os funcionalistas também tratam as mensagens como aspecto físico do processo comunicativo e conferem centralidade na transferência das informações e na funcionalidade dos canais, como já apontamos anteriormente. Conteúdo e

\footnotetext{
${ }^{24}$ Scroferneker (2006) e Marchiori (2008c), por exemplo, em seus respectivos textos apenas descrevem certos aspectos que caracterizam as perspectivas funcionalista e interpretativa. Ambas parafraseiam diversos estudiosos preocupados, de uma forma ou de outra, em explicar tais paradigmas no contexto da comunicação organizacional. No entanto, não observamos claramente nos textos destas autoras reflexões aprofundadas sobre a apropriação destas perspectivas pelos estudos de comunicação organizacional no Brasil.

${ }^{25}$ Faremos esta distinção aqui de forma bem sintética. Para um entendimento mais detalhado das diferenças entre os paradigmas funcionalista e interpretativo, aplicados à comunicação organizacional, confira a tese de doutorado da pesquisadora e professora da Universidade Federal do Paraná Adriana Machado Casali (2006).
} 
significado das mensagens ficam em segundo plano nas análises. Pesquisas sobre direcionamento das mensagens (fluxos), barreiras, distorções (ruídos), filtros, ilustram este foco (PACANOWSKY; PUTNAM, 1983).

Por outro lado, uma visão baseada prioritariamente na perspectiva interpretativa da comunicação requer o deslocamento da centralidade na informação para a ênfase nos significados organizacionais e interpessoais. Concebe-se, assim, que a realidade organizacional é socialmente construída por meio das palavras, dos símbolos e dos comportamentos de seus membros. As organizações, sob a perspectiva interpretativa, são consideradas estruturas complexas, construídas e reconstruídas pelos indivíduos que interagem com as mesmas. Portanto, múltiplos são os objetivos e interesses negociados na busca de uma direção comum no processo comunicacional nas organizações. Sob essa luz, organização e indivíduos passam a ser interlocutores, os quais ora apresentam-se como emissores, ora como receptores. A realidade organizacional é considerada algo socialmente construído pela comunicação, ou seja, por meio das relações de indivíduos com outros. Os pesquisadores que são adeptos à perspectiva interpretativa estudam a comunicação como um processo pelo qual se dá a construção social das organizações. Portanto, estão interessados nos símbolos e nos significados que envolvem as organizações, em como os indivíduos compreendem suas próprias experiências através da comunicação e como enxergam a organização através de seus significados compartilhados (PACANOWSKY; PUTNAM, 1983).

Estes paradigmas sociológicos tem sido incorporados por alguns pesquisadores brasileiros como base para duas coisas: a) tentativa de explicar as orientações do campo de estudos em comunicação organizacional no país, cujo foco tem sido mais próximo à perspectiva funcionalista; b) intenção de nortear a natureza dos estudos, privilegiando a ótica do paradigma interpretativo.

Kunsch (2006), por exemplo, em seus estudos mais recentes, já sugere a perspectiva interpretativa como o caminho mais interessante a ser escolhido ao destacar a relevância da "dimensão humana"26 da comunicação organizacional. Deste modo, pensar um caminho teórico para esta perspectiva é trazer à tona que o universo cognitivo e o repertório de vida dos indivíduos que interagem com a organização são elementos determinantes no processo comunicacional. Os diversos contextos social, político, econômico e cultural em que

\footnotetext{
${ }^{26}$ Kunsch (2006) afirma que a comunicação organizacional pode ser pensada por meio de três dimensões: humana, instrumental e estratégica. E esclarece: "este olhar se aplica tanto em nível acadêmico como nas práticas cotidianas nas e das organizações.” (p.175).
} 
estão inseridas estas pessoas também são variáveis que precisam ser analisadas para a devida compreensão da comunicação nas organizações. Há casos, no entanto, em que não há um claro limite entre o entendimento destas duas perspectivas. Vejamos:

\footnotetext{
"A produção científica do campo teórico da comunicação tem trazido, nas últimas décadas, significativas contribuições e modelos teóricos relativos a questões referentes ao sujeito, à linguagem, à identidade e ao simbólico. Essa discussão se faz presente também na comunicação organizacional, levandose a entendê-la como produtora de sentido estratégico nas organizações, a partir da interação com os atores sociais. Novas abordagens têm sido relevantes para a compreensão e sustentação teórica do processo comunicacional neste campo. Muitas evidenciam a insuficiência do paradigma clássico/informacional para administrar a abundância dos fluxos e demandas informacionais e de relacionamento, colocadas pela sociedade contemporânea às organizações." (OLIVEIRA; DE PAULA, 2007, p. 17).
}

O trecho acima demarca bem uma posição. Parece não ser um caso isolado entre os estudiosos, os quais compartilham do discurso hegemônico da comunicação organizacional, sobre a possibilidade da dimensão estratégica ser compreendida com base no paradigma interpretativo. Mas, por outro lado, o que temos observado é esta dimensão sendo constituída por traços marcantes do paradigma funcionalista, especialmente ao imprimir demasiado interesse à transferência de mensagens no processo comunicativo. Observa-se que quando o foco de análise é a questão estratégica, os estudos de comunicação organizacional acabam caminhando naturalmente para uma perspectiva funcionalista ou mecanicista. Isto é claramente perceptível ao levarmos em consideração a dificuldade em se separar o propósito de contribuir para os negócios da organização - objetivo principal da dimensão estratégica com a idéia de racionalização e aplicabilidade profissional da comunicação, tão presente no funcionalismo.

$\mathrm{Na}$ tentativa de imprimir a ótica da perspectiva interpretativa ao campo brasileiro da comunicação organizacional, alguns estudiosos têm procurado dialogar com abordagens teóricas interessadas nos aspectos simbólicos do processo comunicativo, como é o caso da "Escola de Montreal", o que pode ser positivo nos rumos futuros da área.

Alicerçada pela idéia inicial de que comunicar não é transmitir informações e que organizações não são entidades reificadas, a "Escola de Montreal", desde os anos 1980, tem formulado uma teoria comunicacional das organizações. Adeptos originariamente dos 
princípios da perspectiva interpretativa, pesquisadores e estudiosos canadenses de comunicação organizacional, que integram o movimento intitulado "Escola de Montreal", tentam compreender as organizações por meio da comunicação. Entendem que as organizações são constituídas pelas práticas cotidianas dos indivíduos que interagem com elas. Práticas, estas, que se dão pela comunicação. Deste modo, uma organização não poderia existir sem comunicação.

O principal propósito desta corrente de pensamento é explicar os fenômenos da comunicação organizacional a partir da linguagem e do discurso, levando em conta as dimensões subjetivas bem como as dimensões objetivas no processo comunicativo. Os teóricos da "Escola de Montreal" conceituam a comunicação organizacional como um fenômeno único ao compreenderem que não existe possibilidade de separar organização de comunicação em partes autônomas que se relacionam. A explicação disso se dá, de forma simplificada por meio da idéia que "cada vez que os indivíduos comunicam, organizam e ao mesmo tempo cada vez que organizam, comunicam.” (CASALI, 2006).

Adriana M. Casali (2005a, 2005b, 2006) é uma das pioneiras no Brasil em dialogar com os conceitos da "Escola de Montreal". A produção de sua tese de doutorado, bem como a produção de artigos e trabalhos apresentados em congressos científicos, têm ajudado outros estudiosos da área a compreender melhor, por meio desta abordagem teórica, possibilidades de desenvolver estudos que se aproximem de uma perspectiva interpretativa.

Certamente, existem outras pesquisas de estudiosos brasileiros que analisam os fenômenos da comunicação organizacional com base em paradigmas além daquele centrado na preocupação em analisar a produção e transferência de mensagens. Como também há estudos que permitem outros olhares, cujo interesse principal não é a dimensão estratégica e nem a aplicabilidade de possíveis resultados das pesquisas realizadas. A problemática, na verdade, aparece no momento em que notamos a pouca inserção destes estudos na comunidade científica por meio, por exemplo, de publicações de livros que poderiam ser utilizados nos cursos de graduação e pós-graduação. 


\section{"Comunicação interna": caminhos escolhidos por vozes autorais}

A expressão "comunicação interna” tem sido utilizada no campo da comunicação organizacional para designar, de modo geral, a interação entre funcionários e organizações. Poderíamos arriscar a dizer que, originariamente, esta denominação surgiu para tentar sistematizar como se configuram as relações comunicacionais das organizações com os indivíduos que atuam no seu espaço físico. A delimitação espacial é propositadamente instituída nesta categorização por meio da palavra "interna" que nos remete à idéia daquilo que está dentro de algo. Deste modo, presume-se que a intenção seria de tentar entender e explicar como se dão os processos comunicacionais envolvendo a organização e aqueles que exercem atividades no seu interior, especialmente seus empregados.

Vale lembrar que Torquato (1986), há mais de duas décadas, já tratava a comunicação por meio de duas categorias: comunicação interna e comunicação externa, entendendo que a primeira "é integrada pelas comunicações que se processam no interior do sistema organizacional. São as comunicações elaboradas para o construto da consciência coletiva, no sentido etimológico do termo, que servem para edificar as decisões do ambiente interno, e que se destinam aos que trabalham na organização.” (p.50).

Hoje, a delimitação espacial importa menos para os estudiosos e pesquisadores deste assunto. A designação "comunicação interna" continua sendo empregada quando o propósito é discorrer sobre como se dão as relações entre organizações e trabalhadores por meio da comunicação.

Não é foco de nosso interesse a nomenclatura utilizada; poderia ser "comunicação interna” como qualquer outra. O que nos importa, de fato, é como o campo de conhecimento intitulado "comunicação organizacional" concebe a comunicação nas relações de trabalho por meio dos conceitos de "comunicação interna". 
A área da comunicação organizacional tem se mostrado bastante interessada em discutir, mesmo os estudiosos que não tenham como foco principal esta questão, sobre esta temática por meio de diversos estudos expostos em livros e outros documentos que abarcam os elementos que configuram a interação entre trabalhadores e organizações. Tais estudos apresentam, em sua maioria, concepções bem parecidas sobre esta relação, mostrando a hegemonia de um discurso criado ao longo do tempo e que, atualmente, aparece como traço marcante do entendimento sobre comunicação interna. E muito nos interessa destacar estas concepções que estão incorporadas nas vozes de autores representativos da literatura sobre o assunto para, mais tarde, podermos confrontá-las com a compreensão que a sociologia do trabalho tem sobre a relação entre organizações e trabalhadores.

Vale aqui esclarecer que tentamos desenvolver este capítulo com base nos aspectos que, a nosso ver, são os mais recorrentes no discurso na retórica da comunicação interna. A partir disso foram trazidos autores ${ }^{27}$ significativos na aproximação destes aspectos, compondo as discussões que virão adiante.

Ressalta-se, inicialmente, que é comum se confundirem aportes do campo teórico e do campo profissional ao se falar sobre comunicação interna. Na verdade, isso é bastante compreensível ao lembrarmos, como já discutimos anteriormente, que o campo de estudos de comunicação organizacional tem sido construído pela forte influência das práticas do mercado. Exemplo disso dá-se pelo fato de que um dos aspectos bastante presente nas concepções sobre comunicação interna refere-se à gestão da comunicação entre organização e funcionários. Trata-se de um entendimento que busca incorporar o trabalhador à racionalidade da organização. Para o momento, temos o primeiro aspecto.

Pode-se observar que autores que tratam de comunicação interna, no campo da comunicação organizacional, concebem a comunicação em seus parâmetros mais estratégicos:

\footnotetext{
${ }^{27}$ Fizemos o seguinte levantamento bibliográfico sobre as abordagens de comunicação interna, dentro do campo da comunicação organizacional: Torquato (1986; 2004); Kunsch (2003b); Nassar (2003; 2005b; 2006b; 2006d; 2008b); Marchiori (2006a; 2006b; 2006c; 2008a; 2008b); Curvello (2001; 2002); Oliveira; De Paula (2007); Bueno (2003; 2007). Em relação à exemplificação deste capítulo ficaremos concentrados nos textos de Torquato e Marchiori. A escolha destes dois autores justifica-se pela representatividade de cada um. O primeiro, legítimo representante do que consideramos o pensamento hegemônico da comunicação organizacional, é pioneiro de idéias ainda muito em voga nos cursos de graduação e pós-graduação em comunicação social quando o assunto é comunicação interna. A segunda está no cenário nacional dos últimos anos entre os estudiosos da área que mais produz sobre o tema comunicação interna. Metodologicamente, seguiremos o mesmo caminho trabalhado anteriormente, no capítulo sobre o pensamento hegemônico. Trilharemos as repetições entre as duas produções e não suas supostas diferenças, até mesmo porque não acreditamos que estas diferenças, na essência, são tão substanciais assim.
} 
"A comunicação interna planejada e avaliada é uma ferramenta estratégica que estimula o diálogo entre lideranças e funcionários. Oportuniza a troca de informações via comunicação, contribuindo para a construção do conhecimento, o qual é expresso nas atitudes das pessoas. É fundamentalmente um processo que engloba a comunicação administrativa, fluxos barreiras, veículos, redes, formais e informais. Promove, portanto, a interação social e fomenta a credibilidade, agindo no sentido de manter viva a identidade de uma organização." (MARCHIORI, 2006b, p. 213-214).

É interessante notar a importância que se dá à tentativa de controle do processo comunicacional por parte da organização. O trecho acima demonstra um caráter de recomendação para que a organização preocupe-se em pensar ações direcionadas aos funcionários com base em etapas bem planejadas. Neste sentido, existe a intenção de se objetivar a comunicação com o propósito de se conseguir bons resultados da relação entre organização e trabalhadores. Resultados, estes, que podem, dependendo do ponto de vista, serem mais proveitosos para as empresas do que para seus empregados, apesar da apologia ao comprometimento de interesses entre ambos no discurso da comunicação interna. Tal suposição aparece de forma mais contundente quando se percebe a explanação de benefícios que a organização pode obter com o planejamento da comunicação interna:

"A efetividade do processo de comunicação é um dos maiores desafios da comunicação interna: construir um processo de informação que gere resposta junto aos diferentes públicos para que a credibilidade na organização possa ser uma realidade. Salientamos que iniciar um relacionamento interno é fácil, mas é preciso continuidade para que seja verdadeiro e apreciado pelo grupo. Gestores que praticam a comunicação interna dessa forma estão à frente no processo não só de construção mas, principalmente, de manutenção da credibilidade empresarial junto aos seus públicos." (MARCHIORI, 2006b, p. 215).

Sob a ótica das organizações, indubitavelmente, são interessantes as vantagens que elas terão com a tentativa de administrar sua relação com os funcionários por meio da comunicação. Quanto mais estes forem persuadidos a envolver-se com a empresa e agir conforme seus preceitos, mais eficiente esta se tornará.

Os interesses dos trabalhadores, neste contexto, são lembrados por meio de exaltação ao diálogo, à transparência, à acessibilidade à informação, dentre outros elementos. O discurso da comunicação interna, representado pelas obras de autores do campo da 
comunicação organizacional, demonstra um caráter de orientação educativa à organização ao aconselhá-la a agir de maneira a considerar tais interesses, destacando que isso pode ser positivo para ambos os lados. Certamente que num cenário de grande competitividade no mercado, de intensificação da produtividade e de manutenção na qualidade dos serviços oferecidos, as empresas solicitarão maior comprometimento dos empregados, sendo que, para tanto, exige-se um comportamento de maior envolvimento do funcionário com o funcionamento da organização.

Mais diálogo entre chefias e subordinados, transparência nas ações e disseminação de mais informações para os funcionários são atitudes incentivadas como se estas fossem reivindicações dos próprios trabalhadores e que poderiam apaziguar, de certa maneira, os conflitos existentes entre as classes de trabalhadores e de empregadores ${ }^{28}$. Os autores que constroem o discurso da comunicação interna evitam discussões sobre o embate entre classes sociais na disputa pelo controle do trabalho. Nota-se, por exemplo, a enunciação de um discurso em prol da valorização do empregado como pessoa e como cidadão sem, no entanto, questionar as situações de constrangimento ou de sofrimento do funcionário nas suas relações de trabalho.

Opta-se por não desvendar a oposição de interesses entre trabalhadores e organizações, ao contrário, prefere-se o caminho de tentar suavizar os desdobramentos que as tensões provocam na relação entre ambos e convencer que a comunicação pode facilitar este entendimento, como afirma Torquato:

\footnotetext{
"Gerar consentimentos e produzir aceitação devem ser dois dos principais objetivos da comunicação interna. Trabalhando na direção de obter consenso sobre os sistemas de valores da organização, a comunicação, em determinados momentos, é vital para encaminhar soluções e para se atingir as metas programadas." (2004, p.54).
}

A acessibilidade do trabalhador à informação é outro aspecto marcante do discurso de autores que formulam o discurso da comunicação interna. Há interesse em que os funcionários saibam mais sobre os negócios e o funcionamento da organização. Neste sentido,

\footnotetext{
${ }^{28}$ Exemplo disso é o Plano de Comunicação Social elaborado pela Rhodia na década de 1980 e exaltado pelos estudiosos em comunicação organizacional como uma posição louvável da empresa quanto a sua atitude no relacionamento com seus empregados: "A comunicação interna é uma ferramenta estratégica para compatibilização dos interesses dos empregados e da empresa, através do estímulo ao diálogo, à troca de informações e de experiências e à participação de todos os níveis.” (Rhodia, 1985, apud Kunsch, 2003b, p.154).
} 
incentiva-se que as diretrizes da empresa sejam disseminadas e espera-se que os canais de comunicação para recebimento destas informações pelos funcionários sejam adequados, propiciando mais clareza e rapidez. Os chamados instrumentos de comunicação interna ganham destaque neste contexto: jornais, revistas, intranet, eventos são alguns dos exemplos mais comentados nas obras estudadas para esta análise. Nota-se grande interesse na discussão sobre a operacionalização destes instrumentos, considerados essenciais na construção do relacionamento entre as organizações e trabalhadores:

\footnotetext{
"Em primeiro lugar, o público interno é o grupo que está mais próximo à empresa. O seu comportamento no ambiente desempenha um papel decisivo em sua vida. Qualquer mensagem que diga respeito ao seu trabalho influencia seu comportamento. A publicação interna é o único veículo de comunicação que traz mensagens cujas fontes podem ser os próprios funcionários. Mensagens que interessam também às famílias. Lendo a publicação, o trabalhador pode formar um estado psicológico favorável ao bom desempenho de suas atividades operacionais. E a empresa tem em mãos um instrumento para estímulo funcional, transformando-o no porta-voz de benefícios, promoções, serviços sociais e no melhor meio para o estreitamento das relações humanas." (TORQUATO, 2004, p.59).
}

Não raramente nos deparamos com o argumento que defende a "comunicação de mão-dupla”, ou seja, a idéia de que é necessária e possível a participação dos interlocutores de forma ativa e igualitária, neste caso, dos funcionários e da organização, no processo comunicacional. Em contrapartida, não necessariamente se deixa claro como isso poderia ocorrer de fato, até mesmo porque, segundo nossa concepção, para uma argumentação mais preeminente haveria a necessidade de uma discussão aprofundada sobre o mundo do trabalho e todos os seus aspectos, particularidades quase nunca observadas no discurso da comunicação interna.

As relações de trabalho nas organizações são compreendidas prioritariamente numa dimensão estratégica nos estudos de comunicação interna. Mesmo aqueles que, eventualmente, tentam questionar a perspectiva funcionalista da comunicação, optam por imprimir uma visão de gestão e de busca por efetividade organizacional, tratando a comunicação como ferramenta estratégica. É possível constatar, em alguns casos, a argumentação que supõe contrariar o foco de análise da comunicação interna sob o viés dos instrumentos ou das mídias de comunicação, levando em consideração outros elementos que 
abarcam a concepção de comunicação nas organizações e a relação entre trabalhadores e empresas, como por exemplo, a cultura. Isso, no entanto, não significa que a orientação principal da dimensão estratégica, baseada no propósito de contribuir para o alcance dos objetivos organizacionais, tenha sido esquecida. Pelo contrário, observa-se que novos elementos são incorporados ao discurso da comunicação interna, a qual continua sendo tratada como ferramenta estratégica em apoio às formas de gestão das organizações. Deixa-se, prioritariamente, de falar dos instrumentos, reitera-se, porém, a idéia de comunicação interna como ferramenta estratégica para a gestão organizacional.

Sob esta perspectiva, a abordagem sobre a relação entre comunicação e cultura organizacional tem sido discutida nos recentes estudos de comunicação interna. A comunicação, neste contexto, é compreendida como um processo que produz significados para a constituição das organizações:

"A comunicação instrumentalizada cede espaço para a construção de significados nas organizações. Organizações são processos dinâmicos por meio dos quais os significados são construídos. Estes significados fazem sentido para as pessoas, permitindo o desenvolvimento de relações e provavelmente a construção de novos significados. É indispensável o desenvolvimento de processos mais interativos que permitam às pessoas explorar suas potencialidades e se desafiar como seres humanos. A função da comunicação passa a ser formadora, e não meramente informativa." (MARCHIORI, 2008a, p. 6).

Percebe-se, pelo trecho anterior, que esta nova ótica da comunicação interna, a qual contempla os aspectos da cultura organizacional, explicita sua recusa quanto a pensar a comunicação prioritariamente por meio dos instrumentos de comunicação. Tem como foco principal a interação social entre a organização e seus membros, ou seja, seus funcionários em especial. A comunicação, portanto, apresenta-se como um processo que não se encerra na transmissão de informações, mas, sim, tem como cerne a construção de significados que simbolizem a organização e sua relação com os trabalhadores.

A opção por pensar o processo comunicativo organizacional por meio dos aspectos da cultura organizacional em substituição ao foco nas mídias, no entanto, demonstra realmente o distanciamento de uma perspectiva funcionalista? Não seria, na verdade, a substituição de um aspecto pelo outro para fundamentar a visão de gestão organizacional, 
sendo esta intimamente ligada às tentativas de controlar e administrar os processos comunicativos? Talvez a resposta para tais perguntas seja que, mesmo com a apropriação de aspectos da cultura, como a autora faz, em detrimentos dos instrumentos de comunicação, continua-se a pensar o processo comunicativo de forma próxima à perspectiva funcionalista. Até mesmo porque, sob o nosso ponto de vista, não é possível haver um distanciamento desta perspectiva quando compreendemos a comunicação num processo de gestão.

E não há intenção de Marchiori (2008a) pensar a comunicação organizacional, e consequentemente a comunicação interna, sob outro viés que não seja pela gestão estratégica da comunicação organizacional. Vejamos um exemplo disso naquele mesmo artigo da autora que foi citado anteriormente, utilizado para mostrar a recusa da autora quanto ao que ela denomina de "cultura instrumentalizada":

"A existência do processo de informação estratégica possibilita à organização estar fortalecida, passando o sistema existente a nutrir e sustentar o fluxo sistemático de credibilidade, sensibilidade, temporalidade e informação relevante - nos diferentes fluxos e por meio de suas estruturas. Este posicionamento exige o comprometimento total das lideranças, o uso de tecnologias apropriadas, assim como a participação e suporte abrangente dos funcionários (...).” (MARCHIORI, 2008a, p.8).

Outro trecho encontrado neste artigo também é representativo da idéia de comunicação ligada ao processo de gestão estratégica e, consequentemente, de recomendação às organizações para tentar controlar o processo comunicativo:

"A estratégia organizacional também engloba a maneira pela qual uma organização relaciona-se com o ambiente externo - em nível seja de clientes, seja de concorrentes, seja de fornecedores - como também com a comunidade e o governo entre os quais desenvolve suas atividades. Ao determinar uma estratégia, a organização deve ter clara sua razão assim como a forma de medir o sucesso." (MARCHIORI, 2008a, p.8).

Os autores que compartilham da concepção de pensar a comunicação interna sob os aspectos da cultura ressaltam a função da comunicação em fortalecer a identidade organizacional, ou seja, tornar os valores da empresa - missão, visão, políticas compreensíveis e aceitos pelos funcionários com o propósito de motivar um maior 
comprometimento destes em prol da organização. Certamente, não existe uma postura ingênua por parte das vozes autorais que representam este discurso em julgar que os trabalhadores, de fato, serão incorporados à racionalidade da empresa de forma consensual e sem resistências. Deste modo, optam por imprimir um caráter de centralidade à comunicação como responsável por mediar o embate entre a organização e os trabalhadores, esquecendo, porém, qualquer possibilidade de discutir as relações de trabalho como uma questão primordial neste contexto:

\footnotetext{
"Por que tantos desentendimentos ocorrem? Por que os relacionamentos de trabalho não são fortes? Por que é mais difícil do que poderia ser conseguir que as pessoas façam as coisas?

Entendemos que a comunicação deve olhar para a organização como um complexo. Partindo daí, vemos que a análise da organização levará no seu total entendimento e nos processos comunicativos que ocorrem na interação social e no desenvolvimento das atividades que tenham sentido para as pessoas. A comunicação deve passar a construir significado e ser geradora de novos contextos em todos os relacionamentos organizacionais. Os significados são ativamente produzidos, reproduzidos, negociados e mantidos por meio da interação social. As interações comunicativas e a relação com o contexto passam a ser prioridades na construção de processos de relacionamentos organizacionais." (MARCHIORI, 2008b, p. 12).
}

Não queremos aqui negar a importância da perspectiva de se analisar o processo comunicacional nas organizações com o auxílio dos aportes teóricos que privilegiam os aspectos culturais e simbólicos. Pelo contrário, sabemos as preciosas reflexões possíveis de serem desenvolvidas por meio do diálogo com áreas que centram seus estudos nestes aspectos. O que questionamos aqui se refere à escolha de se continuar tratando a comunicação interna prioritariamente sob a luz da gestão estratégica.

Pensar o processo comunicacional que permeia as relações entre organizações e trabalhadores, a nosso ver, exige o entendimento sobre o fator trabalho e sua influência nesta configuração. Mas não parece ser este o caminho escolhido no percurso da construção do pensamento de comunicação interna no Brasil. Esta breve análise sobre certas vozes autorais que representam, em grande parte, as concepções de comunicação interna no campo de estudos em comunicação organizacional no país nos dá algumas pistas. 


\section{III}

\section{Comunicação e trabalho}

Se comparada ao campo da sociologia do trabalho, a área da comunicação organizacional tem tratado as relações entre trabalhadores e organizações com uma quase que completa, senão total, desconsideração do entendimento do mundo do trabalho na contemporaneidade. E quando tenta apropriar-se de certas temáticas que tangenciam este cenário, na maioria das vezes, as analisa sob a ótica da gestão administrativa e organizacional e raramente sob o olhar mais amplo, calcado nas relações sociais.

É verdade que não raramente encontramos em obras da comunicação organizacional uma certa preocupação em seguir as mudanças nas formas de produção e, consequentemente, nas formas de gestão no mundo organizacional ao longo do último século. Taylorismo, Fordismo, Escola de Relações Humanas, Toyotismo são exemplos de temas que, muitas vezes, são apropriados - mesmo que de forma pouco aprofundada - nos textos destes estudiosos. No entanto, nota-se a escassez de análises que reflitam criticamente o impacto de tais mudanças nas relações entre trabalhadores e organizações, pouco dizendo sobre o lugar da comunicação nesta ambiência.

Os estudos de comunicação organizacional têm passado longe da discussão sobre a centralidade do trabalho na sociedade, hoje, e das mudanças no mundo do trabalho originadas, em grande parte, pela flexibilização das formas de acúmulo do capital. Temas, estes, que podem contribuir para os estudos de comunicação interna posicionarem-se em compasso com a sociedade contemporânea e com as recentes teorias da comunicação sob uma perspectiva mais interpretativa e menos instrumental.

Não é nossa intenção aqui trazer ao leitor uma profunda análise dos assuntos que delineiam o mundo do trabalho. Certamente, os estudiosos da chamada "sociologia do trabalho" já a fazem muito bem. Mas nos parece importante mostrar quais são as temáticas deste cenário que podem nos ajudar a compreender melhor a comunicação nas relações de trabalho. Isto porque como mesmo esclarece Fígaro: 
"A Sociologia do Trabalho contribui para estudarmos como o mundo do trabalho, as forças produtivas dele oriundas, são transformadas com o advento das novas tecnologias da comunicação, ou melhor, das tecnologias para transmissão de informações, ou seja, como os computadores, máquinas inteligentes têm transformado a relação com o trabalho e a produção; como as técnicas de gestão do processo produtivo têm transformado a planta das empresas; como a realidade da produção - máquinas, equipamentos, homens - tem sido reorganizada em função das novas maneiras de produzir; e como os instrumentos de comunicação - máquinas, informações e processos - cada vez mais fazem parte do que se denominam forças produtivas e, portanto, como é neste território que os pesquisadores precisam se debruçar para compreenderem o que está mudando na comunicação, nas sensibilidades, nas formas de ver, ouvir, falar, sentir; comunicar-se." (2008a, p.20).

Instituir o aspecto da natureza do trabalho no tecido das teorias comunicacionais das organizações nos parece ser de suma relevância para um novo olhar que substitua o entendimento de "comunicação interna" para uma concepção de "comunicação nas relações de trabalho". E este será nosso objetivo neste capítulo, visto que formularemos uma discussão sobre aspectos que contribuam para o entendimento de "trabalho" na contemporaneidade e na sua relação com a comunicação.

Serão destacadas algumas questões relevantes e mais amplas sobre o mundo do trabalho contemporâneo. Individualização do trabalhador, valorização da pessoa na organização, acessibilidade à informação no ambiente de trabalho e incorporação do trabalhador à racionalidade da organização são eixos temáticos abordados neste capítulo sob as considerações especialmente de autores originários do campo de estudos conhecido como “sociologia do trabalho". A hipótese é que tais eixos temáticos possam servir de balizadores para refletirmos criticamente sobre o entendimento que a comunicação organizacional, mais especificamente a comunicação interna, tem sobre as relações entre trabalhadores e organizações. 


\subsection{O trabalho como norteador das relações sociais}

Podemos considerar o trabalho como fator principal na vida das pessoas? Ele ainda rege suas outras relações sociais? Ou seja, o trabalho ainda pode ser considerado como um fator social ou mediador na sociedade contemporânea? Ou o trabalho não é mais uma categoria importante para o homem, pois o considera desestimulante e o encara como uma tarefa qualquer desempenhada num emprego qualquer que possa lhe proporcionar apenas sustento?

Não é tão fácil saber qual proposição merece ser considerada como a mais pertinente. Se por um lado levarmos em consideração que o trabalho faz parte da realização do ser humano como um ser social e leva o indivíduo a sentir-se parte da sociedade em que vive, por outro lado, o trabalhador encontra-se numa dinâmica organizacional que tem lhe causado muitos constrangimentos, sofrimento e pouca possibilidade verdadeira de apropriar-se do trabalho que desenvolve. Ao trabalhador, no geral, há pouco espaço para efetivamente criar e transformar o trabalho que realiza sem receber a interferência da organização ou da empresa, com o objetivo principal de direcioná-lo ao que somente interessa para o seu sistema produtivo, ou seja, para a auto-reprodução do capital.

As mudanças ocorridas no mundo do trabalho devido à flexibilização da forma de acúmulo do capital são incontáveis: crescimento do trabalho terceirizado e redução do proletariado fabril estável; aumento do trabalho feminino com condições desiguais em relação ao trabalho masculino (salários menores, piores condições de trabalho, execução de mais tarefas operacionais em comparação com as atividades realizadas pelos homens); expansão do trabalho em domicílio e a inserção inescrupulosa da criança no mercado de trabalho (ANTUNES, 1999).

O crescimento do trabalho terceirizado, part-time, temporário ou precarizado e sem qualificação em sua maioria, mostra-se real nos dias de hoje e tem caminhado junto a um menor número de trabalhadores capacitados para atender às exigências da nova fase do capital. Representado pelo toyotismo, este recente período de reestruturação do capital almeja o trabalhador polivalente e multifuncional com habilidade e esperteza para lidar com as conseqüências da automatização e da informatização do processo produtivo. Minoria, esta, que tem conseguido assegurar sua posição no mercado de trabalho em oposição a uma maioria 
de trabalhadores que sobrevive por meio de empregos precários, de meio-expediente, ocupando postos de serviços terceirizados (ANTUNES, 1999, 2005).

Diante disso, alguns estudiosos (GORZ, 1982; OFFE, 1984) questionam se, hoje, o trabalho (assalariado) realmente pode ser considerado como fator social central na sociedade. Tanto Gorz como Offe acreditam que a racionalidade produtiva e mercantil que, até então, tem orientado as relações sociais está sendo substituída por outro tipo de racionalidade, baseada em valores "abstratos". Defendem que existe uma heterogeneidade de situações de trabalho como: grande variação nas qualificações, nas oportunidades de carreira, na autonomia, no reconhecimento social que, por exemplo, contribuem para caracterizar a esfera do trabalho. Além disso, ressaltam que o trabalho também perdeu sua capacidade aglutinadora de coletividade dos trabalhadores assalariados e, portanto, deixou de apresentar-se como central na vida do trabalhador. Sob esta égide, Offe (1984, p.177) completa: "no que diz respeito aos conteúdos objetivo e subjetivo da experiência, muitas atividades assalariadas nada mais têm em comum a não ser o nome 'trabalho'”.

Gorz (1982, p.87) destaca, até mesmo, a existência de uma "não-classe de nãotrabalhadores", pois afirma que o trabalhador não se identifica mais com o trabalho que realiza e, consequentemente, não se observa mais o sentimento de pertencimento a uma classe:

"Essa não-classe engloba, na realidade, o conjunto de indivíduos que se encontram expulsos da produção pelo processo de abolição do trabalho, ou subempregados em suas capacidades de industrialização (ou seja, pela automatização e pela informatização) do trabalho intelectual. Engloba o conjunto desses extra-numerários da produção social que são os desempregados reais e virtuais, permanentes e temporários totais e parciais." (GORZ, 1982, p. 87).

A intensificação e ampliação do setor de serviços, o qual emprega grande parte dos trabalhadores terceirizados, tem contribuído diretamente para as modificações verificadas nas relações de trabalho na contemporaneidade. Um contingente cada vez maior de trabalhadores que desenvolve atividades não diretamente ligadas ao processo de produção de mercadorias, consegue - de uma forma ou de outra - encontrar oportunidades de trabalho. É o caso dos operadores de telemarketing. Estes trabalhadores do setor de serviços, considerados 
“improdutivos" 29, apresentam-se como um segmento em expansão no mundo contemporâneo do trabalho e relacionam-se com o chamado trabalho "imaterial"30.

Caracterizado de maior dimensão intelectual, o trabalho imaterial apresenta-se em fase de expansão no setor de serviços e nas empresas mais informatizadas. A crescente automatização das organizações e a inclusão de novas tecnologias exigem maior habilidade e conhecimento do trabalhador e, consequentemente, a subjetividade no trabalho é bastante valorizada. Mas, isso não significa que a esfera da produção foi substituída pela esfera da informação, por exemplo. No cenário contemporâneo da reestruturação produtiva do capital é possível observarmos uma maior inter-relação entre o trabalho material e o imaterial.

Por mais que a automatização e a informatização sejam disseminadas nas organizações, o trabalho vivo ${ }^{31}$ é essencial. É certo que observamos a redução do trabalho vivo e a ampliação do trabalho morto pelo capital. Pode-se dizer que existe uma tendência em diminuir e transformar o trabalho vivo em trabalho morto, mas isso não significa que todo o processo produtivo consegue ser automatizado, excluindo-se o fator humano "trabalho", ou seja, não é possível substituir os trabalhadores por máquinas em sua totalidade. O trabalho morto "não pode eliminar completamente o trabalho vivo do processo de criação de mercadorias, sejam elas materiais ou imateriais.” (ANTUNES, 2005, p.27).

A atividade humana é essencial para o trabalho ou, melhor ainda, o trabalho é uma atividade humana. Se por um lado, tal afirmação nos parece clara e objetiva, por outro, tem sido o cerne de um grande debate sobre trabalho material versus trabalho imaterial ou trabalho vivo versus trabalho morto.

Esta discussão tem questionado o trabalho como central nas relações sociais. Para o melhor entendimento do debate, voltemos às idéias de Claus Offe (1984) e André Gorz (1982). Estes autores acreditam que o trabalho vivo perdeu seu valor no sistema produtivo,

\footnotetext{
${ }^{29}$ Considera-se "trabalhador improdutivo", aqui, como aquele que realiza trabalho que não produz mais-valia, isto é, que não é consumido no processo de produção com o propósito de valorizar o capital. Este tipo de trabalho é consumido devido ao seu valor de uso e não como aquele que produz valor de troca (MARX, 2004).

${ }^{30}$ Antunes (1999) compreende que as formas oriundas do trabalho imaterial, isto é, do tipo de trabalho provido de maior dimensão intelectual (como, por exemplo, o desenvolvido na área de serviços) tem se expandido e relaciona-se com o próprio trabalho produtivo: "O avanço do trabalho em atividades de pesquisa, na criação de softwares, marketing e publicidade, é também exemplo da ampliação do trabalho na esfera imaterial. A expansão do trabalho em serviços, em esferas não diretamente produtivas mas que muitas vezes desempenham atividades imbricadas com o trabalho produtivo, mostra-se como outra característica importante da noção ampliada de trabalho, quando se quer compreender o seu significado no mundo contemporâneo.” (ANTUNES, p.125, 1999)

31 "Trabalho vivo" pode ser entendido como atividade desenvolvida pelo ser humano, enquanto por "trabalho morto" entende-se o trabalho automatizado, representado pelo maquinário utilizado na realização desta atividade. Para saber mais sobre isso, confira Antunes (1999; 2005).
} 
sendo substituído fortemente pelas tecnologias e, diante disso, o trabalho não mais é o principal mediador do homem na construção de suas relações sociais. Por outro lado, Ricardo Antunes (1999; 2005), influenciado pelos pensamentos de István Mészáros e Georg Lukács, defende que o trabalho vivo ainda é essencial como força produtiva e o fator trabalho é, sim, central nas vidas das pessoas:

“(...) uma vida cheia de sentido fora do trabalho supõe uma vida dotada de sentido dentro do trabalho. Não é possível compatibilizar trabalho desprovido de sentido com tempo verdadeiramente livre. Uma vida desprovida de sentido no trabalho é incompatível com uma vida cheia de sentido fora do trabalho. Em alguma medida, a esfera fora do trabalho estará maculada pela desefetivação que se dá no interior da vida laborativa." (ANTUNES, 2005, p.65).

A vida exterior ao mundo do trabalho certamente contribui para a construção das relações sociais. As dimensões como família, religião, comunidade e lazer ajudam pautar a existência humana, mas o fator trabalho continua sendo o principal regulador social.

Diante deste contexto, compartilhamos nesta dissertação da idéia que o fator trabalho é determinante para o entendimento da sociedade atual, configurando-se, sobretudo, imprescindível compreender a comunicação como processo mediado pelas relações de trabalho. Isto nos exige conhecer as transformações ocorridas no mundo do trabalho e discutir suas principais implicações para a sociedade.

\subsection{A organização e a gestão da produção na realização do trabalho}

O capital tem passado por uma reestruturação produtiva contínua e busca ganhar forças por meio de novas formas de organização e gestão da produção na realização do trabalho. Historicamente, podemos observar a existência de vários mecanismos que demarcam muito bem o caminho percorrido para o alcance deste objetivo.

O taylorismo, por exemplo, apresenta-se como uma das mais bem elaboradas opções já estabelecidas até hoje. Os princípios da "Gerência Científica", bem conhecidos, especialmente devido ao seu mais importante expoente, Frederick W. Taylor (1978), impactaram fortemente na maneira de realizar o trabalho - especialmente entre o final do 
século XIX e início do século XX -, influenciando a gestão da produção de organizações até os dias atuais. A desagregação do processo de trabalho do conhecimento específico dos trabalhadores, o qual começa a depender diretamente das políticas gerenciais; a separação entre a concepção e a execução do trabalho, distinguindo completamente entre aqueles que pensam qual deve ser a tarefa e como ela deve ser realizada e os que seguem as instruções e executam a tarefa e, por último, a apropriação do conhecimento do trabalhador pela empresa, são os principais princípios que buscaram impor uma forte racionalidade ao processo de trabalho (BRAVERMAN, 1987).

O sistema taylorista intensificou estes princípios ao instituir o controle da gerência sobre a realização da atividade no trabalho, sendo que o conhecimento e a experiência do trabalhador não seriam relevantes, já que este não poderia ter autonomia para tomar quaisquer decisões. O trabalho deveria ser prescrito e a interferência do trabalhador na tarefa a ser realizada precisava ser combatida pela gerência. Todo este pensamento da "Gerência Científica”, desenvolvido por Frederick Taylor, perdurou e deixou uma herança que ainda pode ser vista em alguns aspectos no gerenciamento do trabalho de empresas contemporâneas.

É interessante destacar que outras filosofias de gestão administrativa, surgidas posteriormente ao taylorismo, como a "Escola de Relações Humanas" ${ }^{32}$, parecem não ter conseguido superar este sistema, o que é compreensível quando Braverman (1987) nos lembra que tais filosofias preocupavam-se em adequar o trabalhador ao processo de produção do trabalho e são utilizadas pela empresa preocupada com "a seleção, adestramento, manipulação, pacificação e ajustamento da 'mão-de-obra' para adaptá-la aos processos de trabalho" (BRAVERMAN, 1987, p.84), enquanto a produção continuava a ser planejada por meios dos princípios tayloristas.

Importantes transformações ocorridas com o processo de trabalho assalariado devido, especialmente, à intensificação da cadeia de produção semi-automática nas empresas nas primeiras décadas do século XX - trouxeram à tona um novo modo de gestão do trabalho chamado "fordismo"33. O capitalismo industrial estaria precisando de uma nova regulação do trabalho. Assim, o processo de trabalho apresentou-se como o ponto principal de um tripé do

\footnotetext{
32 A chamada "Escola de Relações Humanas", que tinha como um de seus principais expoentes Elton Mayo, propunha-se originalmente a "humanizar" a administração em oposição aos princípios tayloristas.

${ }^{33} \mathrm{O}$ fordismo pode ser considerado um novo estágio de regulação do capitalismo, com o propósito de superação do taylorismo (AGLIETTA, 1986).
} 
modo de regulação: processo de trabalho, norma salarial e estado do bem-estar (AGLIETTA, 1986).

Este modelo norte-americano apresenta-se orientado pela produção em série de produtos padronizados e com o apoio de grandes estoques. Sob a influência do fordismo, o trabalho tornou-se cada vez mais mecanizado e a separação entre a concepção e a execução do trabalho aumentou. São os sistemas de máquinas que determinam o posto de trabalho, adequando o ritmo do trabalho, e conseqüentemente do trabalhador, com o ritmo da máquina (AGLIETTA, 1986). Assim, a compatibilização entre os setores da empresa tornou-se cada vez mais necessária, caso contrário a produtividade poderia ficar ameaçada. A introdução de novas tecnologias contribuiu para intensificar essa compatibilização, pois auxiliava na eliminação dos "tempos mortos" 34 entre os setores, propiciando novos ganhos de produtividade. Em complemento a este tipo de gestão da produção, as organizações exigiam do trabalhador um conhecimento mais especializado sobre as suas funções.

A partir do início dos anos 1970, observa-se uma crise estrutural do capitalismo devido a diversos fatores de ordem econômica, política, social e ideológica que impactaram no mundo do trabalho (ANTUNES, 1999). Dentre estes, o esgotamento do padrão de acumulação taylorista/fordista de produção aparece como um dos mais representativos.

$\mathrm{O}$ encontro do taylorismo com o fordismo mostrou-se, durante quase todo o período do século XX, como a forma racionalista do processo de organização do trabalho mais bem desenvolvida. Com base numa linha rígida de produção, envolvendo clara divisão de tarefas, forte hierarquização de autoridade, produção em série, repetição de atividades desenvolvidas pelos trabalhadores de forma mecânica em tempo cada vez mais reduzido, este padrão produtivo iniciou-se nas indústrias automobilísticas norte-americanas e difundiu-se por outros países capitalistas. Não se restringiu às indústrias e foi apropriado também por parte do setor de serviços.

Esta forma de produção baseada na intensificação da exploração do trabalho, no entanto, começou a ser duramente questionada pelos trabalhadores. O operariado organizouse mais fortemente contra os métodos tayloristas e fordistas de trabalho e por meio de duras atitudes - como, por exemplo, greves parciais e constestação da divisão hierárquica demonstrou sua insatisfação. A organização dos trabalhadores conseguiu abalar o

\footnotetext{
${ }^{34}$ Compreendem-se "tempos mortos" como os tempos de descanso, paradas, interrupções, ou seja, qualquer tipo de intervalo durante a realização do trabalho.
} 
funcionamento do processo produtivo vigente - taylorista/fordista - em vários países considerados potências industriais.

O fortalecimento da luta de classes entre trabalhadores e patronato e a estagnação econômica visível, desde o período pós-guerra de 1945, apresentam-se como determinantes para a crise do início dos anos 1970. E foi necessária, portanto, uma reorganização das forças do capital com base em novos processos de trabalho para a superação desta crise (ANTUNES, 1999).

Diante desta conjuntura, o "sistema toyota" ou o toyotismo começa a ser introduzido em muitos países do ocidente como uma opção para a dominação da crise. Este sistema industrial japonês, no entanto, apresenta características próprias que precisaram ser analisadas pelas indústrias automobilísticas ocidentais e adaptadas aos países que incorporaram a sua expansão.

Também conhecido como "ohnismo"35, o toyotismo é considerado uma escola japonesa de gestão da produção que tem como um de seus principais propósitos produzir produtos diferenciados em escalas menores, ao contrário do Fordismo que tem como base a produção em série de produtos com características idênticas.

Para o alcance deste objetivo, Onho transforma a Toyota em uma fábrica com uma quantidade mínima de trabalhadores e com a capacidade de reduzir ou aumentar a produção conforme a demanda - fábrica "flexível"- e cria o método Kan-Ban ${ }^{36}$, cuja característica principal é a gestão dos efetivos por meio dos estoques. Em paralelo a isso, incentiva o controle direto sobre os funcionários subordinados e motiva a transparência dos padrões de operação para que as chefias possam visualizar e tomar conhecimento dos problemas existentes na produção (CORIAT, 1994).

As condições históricas para a criação do toyotismo no Japão são bem diferentes daquelas que possibilitaram a constituição do taylorismo e do fordismo no ocidente. A partir do final da década de 1940 e início dos anos 1950, vários são os fatores que contribuíram para a formação deste modelo japonês.

\footnotetext{
${ }^{35}$ A palavra "ohnismo" origina-se de Ohno, nome do engenheiro-chefe da fábrica Toyota.

${ }^{36}$ Entende-se por Kan-Ban como uma espécie de cartão de sinalização que controla as etapas de produção de uma fábrica. O Kan-Ban é utilizado para informar quando é necessário produzir mais peças porque o estoque acabou.
} 
A transformação do "sindicato de indústria" para o "sindicato de empresa"37; o sistema de "emprego vitalício" e de "salário por antiguidade" são alguns exemplos destes fatores. Houve "um conjunto de contrapartidas implícitas ou explícitas, dadas aos sindicatos e aos trabalhadores das grandes empresas em 'troca' de seu engajamento na produção" (CORIAT, 1994, p.46) que perimitiram a introdução do próprio sistema Kan-Ban.

Concomitantemente ao Kan-Ban, Ohno aplicou os princípios de linearização da produção e do entendimento da polivalência dos postos de trabalho na indústria automobilística, já utilizados pela indústria têxtil japonesa. O objetivo era transformar os operários fragmentados em trabalhadores multifuncionais ou polivalentes, capazes de desenvolver várias atividades na empresa:

\begin{abstract}
"Sejamos bastante claros. Este movimento de despecialização dos operários profissionais e qualificados, para transformá-los em trabalhadores multifuncionais, é de fato um movimento de racionalização do trabalho no sentido clássico do termo. Trata-se aqui, também - como na via taylorista norte-americana-, de atacar o saber complexo do exercício dos operários qualificados, a fim de atingir o objetivo de diminuir os seus poderes sobre a produção, e de aumentar a intensidade do trabalho. E os operários qualificados viveram efetivamente este movimento de despecialização como sendo um ataque ao seu exercício profissional e ao poder de negociação que este mesmo exercício autorizava." (CORIAT, 1994, p.53).
\end{abstract}

A racionalização do trabalho no toyotismo dá-se, portanto, por meio da despecialização e do tempo partilhado, diferentemente do taylorismo, cujas características principais baseiam-se na parcelização e no microtempo. Ambos buscam, entretanto, a intensificação do trabalho.

O método japonês destaca a racionalização do trabalho baseada em quatro principais pontos, conforme Coriat (1994, p.58) nos mostra: a) polivalência e pluriespecialização dos trabalhadores; b) funções de diagnóstico, reparo e manutenção voltam para as mãos dos operadores de máquinas; c) reintrodução das tarefas de controle de qualidade nos próprios postos de fabricação e não mais centralizada na gerência e d) reagregação das tarefas de planejamento às tarefas de fabricação.

\footnotetext{
37 "Sindicato de empresa" é considerado uma forma de organização dos trabalhadores que funciona sob as regras da própria empresa, ou seja, age em anuência permanente com os interesses do patronato.
} 
Tais princípios organizadores foram aplicados sob condições específicas da indústria automobilística japonesa, representadas pela linearização ${ }^{38}$ da produção e pelas técnicas de gestão da qualidade.

O padrão japonês de produção, considerado como um "padrão de acumulação flexível" é, em certa medida, distinto do padrão taylorista/fordista de acumulação:

"Ele se fundamenta num padrão produtivo organizacional e tecnologicamente avançado, resultado da introdução de técnicas de gestão da força de trabalho próprias da fase informacional, bem como da introdução ampliada dos computadores no processo produtivo e de serviços. Desenvolve-se em uma estrutura produtiva mais flexível, recorrendo frequentemente à desconcentração produtiva, às empresas terceirizadas etc. Utiliza-se de novas técnicas de gestão da força de trabalho, do trabalho em equipe, das 'células de produção', dos 'times de trabalho', dos grupos 'semiautônomos', além de requerer, ao menos no plano discursivo, o 'envolvimento participativo' dos trabalhadores, em verdade uma participação manipuladora e que preserva, na essência, as condições do trabalho alienado e estranhado." (ANTUNES, 1999, p.52).

O toyotismo mostrou-se como um modelo inovador e que proporcionava reais ganhos de produtividade às indústrias japonesas, despertando o interesse dos empresários e governos de países do ocidente. A apropriação do método japonês em países ocidentais ocorreu de forma diferenciada. Cada qual mesclou algumas técnicas do toyotismo com as suas práticas já existentes. Fatores determinantes para a boa aplicação do toyotismo, como a promessa da estabilidade do trabalhador no emprego, por exemplo, não foram seguidos à risca pelas indústrias ocidentais. Estas acabam prestando mais atenção às orientações quanto às relações sociais de trabalho: "retém-se então do modelo a idéia de que sua eficácia repousa sobre a individualização das relações de trabalho e de produção.” (CORIAT, 1994, p. 170). A partir disso, algumas técnicas como o círculo de controle da qualidade são reproduzidas com

\footnotetext{
${ }^{38}$ A linearização da produção implica em produzir por meio da flexibilidade do trabalho. Neste caso, é possível aumentar a produção - caso a demanda solicite - sem aumentar o número de mão-de-obra. A linearização é caracterizada pelas instalações na fábrica em forma de " $U$ " - contribuindo para a verificação da demanda pelo trabalhador, visto que a "entrada" e a "saída" da linha estão uma na frente da outra -, pela mobilização dos trabalhadores multifuncionais e no recálculo contínuo dos padrões de operação dos trabalhadores (CORIAT, 1994).
} 
mais intensidade e criam-se estratégias ${ }^{39}$ para se conseguir o engajamento/envolvimento do trabalhador com a empresa, e consequentemente o aumento da produtividade.

Nesta mesma direção, Durand (2003) destaca alguns fatores que têm contribuído para a atual intensificação da produtividade das empresas: as reorganizações do trabalho e da produção e um recente modo de mobilização dos trabalhadores, cujo sistema integrado ele chama de "nova combinatória produtiva". Tal combinatória configura-se através de três eixos “a integração reticular (organização geral da produção de bens e serviços), a generalização do fluxo tensionado (com suas conseqüências sobre a organização do trabalho) e o modelo da competência como novo regime de mobilização da mão-de-obra." (DURAND, 2003, p.140).

Estamos diante de um cenário que impulsiona o aumento da intensidade do trabalho. Ao empregado é solicitado que compartilhe de um ciclo produtivo que exige atenção redobrada à qualidade dos produtos e serviços, capacidade em agir preventivamente a qualquer imprevisto; ter predisposição para trocar de função e adaptar-se às mudanças então surgidas; zelar pelo ambiente organizacional e buscar sempre a melhoria do processo do trabalho.

Ao mesmo tempo, cada vez mais se incentiva que o trabalho seja realizado coletivamente sob a tutela de grupos de trabalhos. Nestes não há exatamente postos de trabalho e o empregado passa a ser responsável não só por sua tarefa, mas, inclusive, por todo o processo que validará a eficiência dos indivíduos e a qualidade do produto e do serviço realizado. As responsabilidades coletivas levam a uma grande pressão vinda dos próprios companheiros de trabalho, visto que se um indivíduo falhar, todos serão prejudicados. Dessa forma, o fato da ausência da figura do chefe que prescreve e controla o trabalho não minimiza a pressão no ambiente de trabalho. Ao contrário, já que existe mais do que "um par de olhos" observando o empregado integralmente.

$\mathrm{O}$ empregado, neste fluxo tensionado ${ }^{40}$, em que precisa adaptar-se às exigências das empresas, sob a perspectiva de uma crescente responsabilização pelo processo do trabalho, passa por diversas situações de constrangimento e de sofrimento na organização em que atua. Caso não atendam aos objetivos e metas do grupo de trabalho, e conseqüentemente da empresa, os empregados sofrem humilhações de seus pares e também devido a sua própria

\footnotetext{
39 Veremos mais adiante que a própria comunicação interna aparece como uma das estratégias para o envolvimento dos trabalhadores com os objetivos das organizações.

${ }^{40}$ Durand (2003, p.139) explica que o que ele chama de "fluxo tensionado" "é um paradigma que organiza a disciplina (e o modo) do trabalho por meio do fluxo contínuo de todas as atividades (incluindo o trabalho intelectual)".
} 
pressão pessoal, já que se sentem fracassados como profissionais e temerosos pela perda do emprego.

A falta de estabilidade do trabalhador no emprego, gerada, em grande parte, pelas próprias organizações, tem dificultado o desenvolvimento do modelo japonês de produção de acumulação flexível de forma apropriada:

“(...) ao mesmo tempo em que os trabalhadores devem demonstrar 'espírito de cooperação' com as empresas, condição geral para a 'boa implementação' do modelo de tipo toyotista, sua efetivação concreta tem se dado em um solo de frequente instabilidade. A possibilidade de perda de emprego, ao mesmo tempo em que empurra o trabalhador para a aceitação desses novos condicionantes cria uma base desfavorável para o capital nesse processo de 'integração', na medida em que o trabalhador se vê constantemente sob a ameaça do desemprego. Essa contradição no interior do espaço fabril tem se mostrado como um dos elementos que mais dificultam para o capital a implementação de um processo de 'envolvimento' da classe trabalhadora" (ANTUNES, 1999, p.83).

O trabalhador também não encontra solidariedade nem companheirismo por parte dos outros empregados e percebe que, na verdade, só pode contar consigo mesmo, o que contribui para sua individualização no processo do trabalho (MELLO E SILVA, 2006). Sentese inseguro e ameaçado pelos "colegas de trabalho" e apesar de integrar um grupo, o apoio coletivo neste caso quase não existe.

A organização intensifica o tratamento ao empregado de forma individualizada, pois isso contribui para sua participação e seu comprometimento com os objetivos da empresa. O enfraquecimento do coletivo e o incentivo à individualização do trabalhador apresentam-se como uma das estratégias utilizadas pelas empresas no mundo atual do trabalho com os propósitos de responder às exigências de produção impostas pelo mercado competitivo e de conseguir manter seu controle sobre a mão-de-obra.

Sob os moldes do método da gestão taylorista, se a forma encontrada para arregimentar os empregados esteve baseada na premissa da separação entre a concepção e a execução do trabalho - controlando-se o que é prescrito, obrigatório e executado e remunerando-se com base na premissa de que se ganha o equivalente às horas trabalhadas na organização -, hoje, os gestores organizacionais procuram formas de mobilização do trabalhador fundadas na sua individualização, práticas baseadas no toyotismo. 
A empresa espera que o indivíduo "trabalhador" encontre maneiras de ser mais produtivo e, em contrapartida, ela o "premia" com bônus no salário, possíveis promoções e, até mesmo, horários de trabalho individualizados e reuniões individuais com a direção. Mello e Silva (2006) destaca que, nesse sentido, existe o que ele chama de "sociabilidade privada", ou seja, distanciamento do indivíduo do mundo público e uma identificação cada vez maior com a empresa:

“(...) na insegurança do mundo público, a empresa lança meios de pertencimento interno, querendo construir uma espécie de 'casa', onde o seu interior compense as faltas do exterior, quer dizer, tudo é limpo, asseado, as regras são claras e seguidas por todos, há médicos, dentistas, cesta básica, quadra de futebol, enfim, o que o trabalhador não encontra na rua, no local onde mora, ele pode encontrar na empresa (...)" (MELLO E SILVA, 2006, p.5).

A empresa solicita o comprometimento e o envolvimento do trabalhador com as novas formas de gestão, com a produtividade. Ele deve se mostrar cooperativo aos objetivos organizacionais. E para tanto utiliza cada vez mais a estratégia da valorização do indivíduo no ambiente de trabalho por meio de determinadas atitudes, em que se destacam: o oferecimento de suposta maior autonomia ao trabalhador; o incentivo à realização do trabalho da melhor forma na busca pela qualidade; a possibilidade do indivíduo de ganhar mais caso aumente sua produção e cumpra suas metas; estímulo ao aperfeiçoamento profissional que possibilite ao trabalhador polivalência de conhecimento.

Tal discurso baseado na valorização das pessoas contribui para uma individualização da relação entre os empregados e a organização, seus superiores e a direção. O trabalhador aparece como cúmplice e como ator da empresa, cooperando com ela e com aqueles que a administram. Tratar o trabalhador de forma a destacar sua individualidade facilita a sua incorporação à racionalidade da empresa, visto que, como membro de uma coletividade, poderia adquirir muitos valores não interessantes e não controláveis pela empresa (LINHART, 2007).

Quando o trabalhador incorpora-se à racionalidade da organização, ele admite os princípios e os valores organizacionais como idênticos, ou pelo menos bem parecidos com os seus próprios. E para que isso realmente tenha grandes chances de acontecer, a empresa utiliza diversos procedimentos que supostamente possibilitam o empregado a acreditar que está 
participando diretamente na gestão do seu trabalho como, por exemplo, a participação nos círculos de qualidade.

Linhart (2007) ressalta, também, a comunicação como um dos meios utilizados pela empresa para que os trabalhadores se integrem à sua política de forma individualizada, destacando a circulação de uma gama variada de mensagens na organização com o propósito de aumentar a confiança do trabalhador na empresa. Traz à tona, aliás, uma constatação que, inclusive, é percebida fortemente nas organizações brasileiras: apesar dos esforços e investimentos da empresa em comunicação, os funcionários estão constantemente reclamando da falta de informação sobre o que acontece realmente na empresa e sobre o que pode vir a acontecer tão logo.

"É um paradoxo essa queixa da falta de informação, enquanto a comunicação da empresa ganha importância cada vez mais forte? Não, principalmente se levarmos em conta que se trata de uma informação maciçamente orientada por objetivos bem precisos e que não tem muito a ver com uma informação sobre os acontecimentos que focam diretamente os assalariados em sua vida no trabalho assim como seu futuro." (LINHART, 2007, p.111).

A acessibilidade à informação e a possibilidade de expressão do empregado no ambiente organizacional são pontos muito bem pensados e planejados pelos gestores organizacionais. Existe uma articulação de interesses entre a empresa e os empregados muito bem conduzida por estes gestores. Se por um lado existe a possibilidade dos trabalhadores dialogarem com seus superiores e, com isso, sejam informados sobre as questões que envolvem a organização, por outro, a empresa somente lhe possibilitará tal direito à expressão em momentos de controle e contenção. Nesse sentido, Linhart ressalta:

"Na verdade, não se deve enganar: o que acontece parece muito mais um esforço de racionalização, um esforço de prescrição da subjetividade individual e coletiva dos assalariados do que uma renúncia aos princípios fundamentais do taylorismo." (2007, p.121).

Neste contexto, a subjetividade do empregado tem sido crescentemente alvo da gestão do trabalho na contemporaneidade. 


\subsection{A subjetividade no mundo do trabalho}

As transformações do sistema produtivo que o capital tem passado implicam numa contínua renovação das práticas e dos processos de gestão em prol da eficácia do trabalho nas empresas. Atividades e tarefas desenvolvidas em grupo ou em equipe, polivalência de funções e total responsabilização pelo desenvolvimento de produtos e prestação de serviços são algumas das imposições que os trabalhadores têm enfrentado em seu ambiente de trabalho na contemporaneidade.

O discurso empresarial solicita que o trabalhador disponibilize outros esforços que vão além de seus conhecimentos técnicos ou profissionais. Anuncia-se, neste sentido, que o indivíduo precisa saber interagir com o trabalho que está realizando, respondendo eficientemente às tarefas já preestabelecidas e aos acontecimentos imprevistos que influenciam o processo produtivo. Dessa forma, as questões que envolvem a subjetividade do trabalhador aparecem como pauta de discussão nos campos de estudos sobre o trabalho e também em outras áreas que dialogam com tal categoria social, como é o caso da comunicação.

Tal debate realmente mostra-se relevante para um melhor entendimento do processo e das práticas comunicacionais nas relações de trabalho, visto que comunicação é considerada um elemento de grande importância na mediação do trabalhador com seu trabalho e com a organização em que atua.

A valorização da subjetividade no trabalho apresenta-se como um reflexo do processo de modernização das relações de trabalho nas novas formas de gestão administrativa e organizacional e não necessariamente tem contribuído de forma positiva para a relação que o trabalhador tem com o seu trabalho.

Apesar de autores como Zarifian $(2001 ; 2006)$ acreditarem na idéia de que realmente se observa uma melhora da qualidade de vida do trabalhador com este tipo de valorização, outros autores, como Linhart (2007), relativizam esta questão, pois consideram que as tentativas de racionalização da subjetividade por parte da organização têm proporcionado circunstâncias problemáticas para a vida do trabalhador, dentro e fora da empresa. 
Participação, engajamento, motivação e integração são terminologias que começam a ganhar força no discurso empresarial contemporâneo. O que no passado parecia não ser determinante para o aumento da produtividade organizacional, agora é relevante às novas formas de acumulação do capital. A subjetividade agora divide espaço com a razão no desenvolvimento do trabalho. O trabalhador, diferente do que acontecia no sistema taylorista, atualmente é motivado pelas organizações a interferir na realização do trabalho por meio não somente de seus conhecimentos técnicos e empíricos, mas, inclusive, por meio de seu engajamento e da responsabilização de suas ações quanto ao trabalho a ser realizado.

Esta forma de gestão nas empresas ultrapassa os princípios do taylorismo/fordismo já que não limita o empregado às tarefas a serem realizadas em seu determinado cargo. A esta luz, o trabalhador é motivado a compreender as estratégias, os objetivos e as metas abrangentes da empresa, esforçando-se em ser um participante ativo de todo o desenvolvimento organizacional. No entanto, este aspecto parece significar um maior assujeitamento do trabalhador aos interesses econômicos da organização em que atua, conformando-se perfeitamente à "nova combinatória produtiva" defendida por Durand (2003). Esta configuração esclarece que o fluxo tensionado do processo de trabalho comporta a prescrição baseada nos objetivos e não mais nas tarefas, levando a um controle da lealdade dos empregados ao invés do controle sobre o trabalho. A subjetividade do trabalhador, portanto, estaria direcionada para colaborar com os interesses organizacionais, seus objetivos de produtividade e lucratividade.

O chamado "modelo de competência" - elemento presente nas atuais formas de gestão organizacional - também trata a questão da subjetividade na realização do trabalho. No entanto, sob uma ótica diferente daquela que denuncia a sua apropriação pelas empresas como tentativa de controlar a sua relação com o trabalhador. Os simpatizantes deste modelo entendem a valorização da subjetividade do empregado pelas organizações como um aspecto benéfico a ele.

Sob este prisma, temos o modelo de competência pensado por Zarifian (2001, 2006), baseado nos pilares da "autonomia" e do "assumir responsabilidade" por parte do trabalhador. Segundo o autor, seria uma aceitação de que o trabalho precisa ser concebido pelo próprio empregado. A precedência do trabalho sobre quem o exerce tenderia, assim, a desaparecer. Os saberes advindos da experiência de vida de cada trabalhador, juntamente com seus conhecimentos técnicos, possibilitariam a ele tornar-se sujeito de sua própria atividade 
profissional. Fleury (2001) reforça esta visão ao acreditar que o modelo de competência pode acrescentar "valor social" para o trabalhador, além de agregar valor econômico para a empresa. Embora não deixe explícito o que denomina de "valor social" e nem diz como este poderia ser agregado ao indivíduo, o texto de Fleury nos oferece pistas para o entendimento do ponto de vista dos simpatizantes deste modelo ao definir competência como "um saber agir responsável e reconhecido, que implica mobilizar, integrar, transferir conhecimentos, recursos e habilidades, que agreguem valor econômico à organização e valor social ao indivíduo." (FLEURY, 2001, p.188). Este conceito se aproxima muito daquele que Zarifian (2001; 2006) defende. O modelo de competência propiciaria, assim, uma maior autonomia para o trabalhador e conta com sua inteligência na realização do trabalho. E isso, conseqüentemente, segundo estes autores, poderia contribuir para que o empregado pudesse ser compreendido como sujeito do trabalho que realiza e não simplesmente executor de tarefas prescritas.

Este tipo de discurso apresenta aspectos tidos como progressistas e civilizatórios. Quem poderia se opor à possibilidade do trabalhador ter mais liberdade intelectual e moral, podendo opinar para desenvolver seu trabalho? Alguém não concordaria claramente com a idéia do trabalhador ter mais qualificação profissional para conseguir melhores empregos e remunerações?

Certamente que não. Por outro lado, uma reflexão mais crítica relevaria que este discurso pode ter sido construído na tentativa de envolver o trabalhador com os interesses organizacionais, até mesmo porque não é difícil observar as condições opressivas e de constrangimento moral que os trabalhadores têm sido submetidos constantemente nas organizações.

As percepções baseadas no "modelo de competência", portanto, nos parecem passíveis de serem questionadas. A redução da divisão rígida entre elaboração e execução do trabalho pode até contribuir para estimular a sua esfera subjetiva. Mas isso não significa que esta dimensão subjetiva manifestada no processo de trabalho seja verdadeira:

"Além do saber operário, que o fordismo expropriou e transferiu para a
esfera da gerência científica, para os níveis de elaboração, a nova fase do
capital, da qual o toyotismo é a melhor expressão, retransfere o savoir-faire
para o trabalho, mas o faz visando apropriar-se crescentemente da sua
dimensão intelectual, das suas capacidades cognitivas, procurando envolver
mais forte e intensamente a subjetividade operária. Os trabalhos em equipes,
os círculos de controle, as sugestões oriundas do chão da fábrica, são 
recolhidos e apropriados pelo capital nessa fase de reestruturação produtiva." (ANTUNES, 1999. p.131).

Conhecimento e informação são fatores determinantes para o bom funcionamento das organizações atualmente, visto que os processos produtivos tornaram-se cada vez mais complexos. Deste modo, o trabalho humano tem sido peça-chave para as empresas, as quais têm procurado mobilizar a subjetividade do trabalhador por meio de diversas estratégias que buscam promover a valorização do empregado como pessoa, a sua individualização e a acessibilidade à informação no ambiente organizacional. O enaltecimento destes aspectos, por outro lado, tem contribuído para o mascaramento da opressão e do sofrimento causados pelas ações concretas no trabalho.

\subsection{Trabalho e comunicação: mediações}

Partilhamos da hipótese teórica que a comunicação é mediada fundamentalmente pelas relações de trabalho (FÍGARO, 2008a; 2001a) ${ }^{41}$. Isso não significa que desconsideramos a possibilidade de haver outras mediações. A comunicação certamente não é determinada somente pelo trabalho. Existem outras esferas sociais como as artes, a religião, a política, dentre outras, que poderiam justificar a existência da comunicação. Mas entendemos, nesta dissertação, que analisar os processos comunicativos por meio das configurações do mundo do trabalho é essencial, pois, como discutimos anteriormente, o trabalho continua sendo o principal fator que norteia as relações sociais, as quais são constituídas pela própria comunicação.

\footnotetext{
${ }^{41}$ Os estudos de Roseli Fígaro Paulino têm despertado grande interesse de nossa parte, dos quais nos aproximamos, sob certos aspectos, nesta dissertação. A professora da Escola de Comunicações e Artes da Universidade de São Paulo defendeu sua tese de doutorado, em 1999, intitulada "Estudo de Recepção: o mundo do trabalho como mediação da comunicação", nesta mesma instituição, em que realizou uma interessante pesquisa com operários de uma grande montadora do ABC paulista com o propósito principal de estudar a recepção que estes trabalhadores fazem dos meios de comunicação. Desde então, tem divulgado artigos, apresentado trabalhos científicos e publicado livros sobre o binômio comunicação e trabalho. Também coordena o Grupo de Pesquisa "Comunicação e Trabalho", criado em 2003 e apoiado pelo CNPq e pela FAPESP. Para saber mais sobre este grupo de pesquisa e seus estudos desenvolvidos, acesse o endereço eletrônico www.eca.usp.br/comunicacaoetrabalho.
} 
Além do mais, se a proposta aqui é deter a nossa análise no âmbito da comunicação organizacional, nada mais coerente que considerar o trabalho como um fator indispensável nos estudos deste campo científico. Na condição de lugar onde os indivíduos produzem, a organização está diretamente relacionada ao fator trabalho para o seu desenvolvimento e sua sobrevivência. E a comunicação completa este quadro ao propiciar avanços no modo de produção - especialmente por meio de novas tecnologias - que estruturam o funcionamento das organizações. O trabalho no ambiente das organizações também tem sido modificado pelos processos comunicativos. Faz-se necessário, portanto, tentar compreender qual tem sido o papel da comunicação organizacional nas mudanças ocorridas no conjunto das relações de trabalho nas organizações, especialmente no que condiz ao relacionamento entre organizações e trabalhadores. Estudar a comunicação nesta perspectiva é compreendê-la como um fenômeno que extrapola o caráter de transferência de mensagens.

Ao compartilhamos da hipótese teórica que o trabalho é o principal fator de mediação das relações de comunicação, também estamos procurando entendê-las dentro de um processo histórico calcado pelo embate de forças entre os que possuem os meios de produção e aqueles que vendem a sua força de trabalho. Configuração, esta, que tem resultado na exploração da força de trabalho e no acúmulo de capital.

Sob este viés, os processos comunicativos não podem ser compreendidos unicamente como um processo de relação entre as pessoas:

“(...) eles constituem realidades históricas, que estabelecem determinadas relações sociais, definem certos padrões de linguagem e criam uma pauta de conversação, profundamente comprometida com a estrutura de poder e modo de produção vigente da sociedade. $\mathrm{O}$ consenso em que esses processos se baseiam não resulta do livre acordo entre as pessoas: é resultado da consolidação de certas relações de força, que se materializam em determinadas formas de comunicação." (RUDIGER, 1998, p.69).

É possível considerarmos que originalmente a comunicação surge como principal condição para a existência das relações sociais e, conseqüentemente, para a possibilidade de atuação conjunta das pessoas que tinham a necessidade de produzir para o seu próprio sustento. Sem o estabelecimento de relações sociais, não conseguiriam trabalhar e, para construir estas relações, os indivíduos precisavam comunicar-se. Deste modo, a comunicação 
aparece como motivo para a existência de relações entre as pessoas. No entanto, esta condição modificou-se, tornando a comunicação parte de um processo histórico configurado pelos próprios modos de produção.

Ao longo do tempo, as relações entre as pessoas desenvolveram um modo de produção baseado na divisão do trabalho, o qual acabou sendo o motivo da existência do próprio trabalho. E, a partir do momento em que o trabalho foi dividido entre aqueles que administram a maneira de produzir e os que realizam o trabalho, a comunicação acaba tornando-se representante daqueles que possuem mais força neste processo, ou seja, dos controladores dos modos de produção. Se antes a comunicação existia para possibilitar a ação conjunta entre os homens, agora é apropriada como um instrumento político no embate de interesses entre aqueles que possuem os meios de produção e entre aqueles que vendem a sua força de trabalho, ou seja, entre organizações e trabalhadores.

Os interesses entre trabalhadores e organizações são diferentes, podendo em alguns momentos serem compartilhados, mas essencialmente são distintos. Há um jogo de forças em que não se ganha sempre, nem se perde sempre, é verdade, mas que certamente os controladores dos meios de produção e, conseqüentemente, da maior força política, conseguem impor seus interesses com mais êxito.

À luz desta configuração, surge um cenário de conflitos e resistências entre os interlocutores do processo comunicativo que o campo brasileiro da comunicação organizacional não se deteve. Desenvolve-se prioritariamente, em nosso entender, um campo científico sob a condição de produtor de estratégias de comunicação em prol do bom funcionamento da empresa, numa forma de gestão e administração dos interesses organizacionais.

Apesar de exaltar o discurso que defende a comunicação simétrica de mão dupla, em que tanto as organizações como os trabalhadores podem ser atores sociais do processo comunicativo na busca de uma harmonização de interesses, a comunicação organizacional representa, por meio de sua dimensão estratégica hegemônica, certa prioridade à ótica empresarial. Esta preferência teórica, acadêmica e metodológica é uma escolha que deve ser respeitada, até mesmo devido aos seus mais de quarenta anos de tradição disseminados nos cursos de graduação e de pós-graduação em importantes universidades do país. Tampouco queremos, nesta dissertação, tratar o trabalhador como receptor passivo nas relações de comunicação ou como vítima da lógica capitalista. Ao contrário, nossa percepção considera o 
trabalhador como um ser social que não é alienado às condições históricas e sociais que vivencia, produzindo resistências à tentativa de aliciamento de sua subjetividade pelas organizações. Tudo isso, no entanto, não nos impede de analisar criticamente os aportes da comunicação organizacional que demonstram sua aproximação e consonância com o discurso empresarial sobre o mundo do trabalho, deixando em segundo plano a compreensão das relações entre trabalhadores e organizações na sociedade contemporânea, cujas contradições sociais são inúmeras.

Constatamos nas leituras realizadas de obras dos autores brasileiros da comunicação organizacional, especialmente daqueles de comunicação interna (veja-se o capítulo II), o tratamento de certos aspectos concernentes ao mundo do trabalho. Embora de forma diferente, são aspectos que também são arrolados nas discussões dos estudiosos da sociologia do trabalho apresentados ao longo deste capítulo. Individualização do trabalhador, valorização da pessoa na organização, acessibilidade à informação no ambiente de trabalho e incorporação do trabalhador à racionalidade da organização foram os temas escolhidos por nós para serem refletidos, pois, se por um lado, são alvos de grande interesse por parte de representativos autores da sociologia do trabalho, por outro, aparecem como balizadores do discurso da comunicação interna.

Vejamos o caso da voz institucional da ABERJE.

Partindo do pressuposto que esta voz traz consigo uma forte influência, sendo ela também formadora da área de conhecimento da comunicação organizacional no Brasil, no próximo capítulo, faremos a leitura da revista Comunicação Empresarial, a voz representativa da ABERJE, tendo em vista para tal análise o olhar e as concepções de arranjos feitos pela sociologia do trabalho.

Deve-se, mais uma vez, frisar que não temos a pretensão de modificar a tradição dos estudos brasileiros de comunicação interna quanto ao seu interesse em pesquisar a utilidade que a comunicação pode trazer em prol do bom funcionamento da organização, por meio da tentativa de harmonização de interesses da classe trabalhadora e da organização no ambiente de trabalho. Esta última representada pelos administradores e/ou gestores do capital, bem como pelos altos funcionários que detêm o controle hierárquico e de comando do processo de trabalho. Mas certamente um olhar reflexivo sobre esta ótica pode revelar novos caminhos para se pensar as relações entre trabalhadores e organizações por meio da comunicação. 


\section{IV}

\section{ABERJE: as práticas de comunicação interna e as ressonâncias na comunicação organizacional}

Como já destacamos anteriormente, o delineamento da área de conhecimento da comunicação organizacional no Brasil desenvolveu-se, e ainda forma-se, em grande parte, pelas práticas profissionais. Preocupações de ordem pragmática, centradas na reflexão sobre o processo comunicativo na busca de melhorar a gestão organizacional, têm sido o foco principal dos estudos da área em questão na atualidade, incluindo os estudos de comunicação interna.

Neste contexto de configuração da comunicação organizacional pensada como dimensão estratégica, a ABERJE, hoje conhecida como Associação Brasileira de Comunicação Empresarial, ganhou grande espaço e tem conseguido disseminar seus preceitos frente aos estudiosos da área no país. Mais adiante, quando das análises, exploraremos mais esta hipótese ora aqui levantada. Criada na década de 1960, inicialmente para incentivar a profissionalização da atividade de jornalismo empresarial, hoje esta associação tem como um de seus principais propósitos o reconhecimento da comunicação nos planejamentos estratégicos das organizações.

A difusão dos pensamentos da ABERJE nos cursos de graduação e pós-graduação de comunicação social, especialmente de Relações Públicas, tem sido bastante significativa por meio de suas publicações e das parcerias que frequentemente realiza com universidades públicas e privadas, buscando, segundo ela, qualificar os estudantes para atuar no mercado de trabalho. Mediante suas ações de teor educacional e de formação profissional, a associação também tem orientado os conceitos e práticas de comunicação interna nas organizações brasileiras. Muitos dos cursos, fóruns e congressos que realiza são direcionados para a discussão sobre o relacionamento entre funcionários e empresas por meio da comunicação. 
Deste modo, a ABERJE foi escolhida como um dos objetos de análise desta dissertação porque representa não somente o campo de atuação profissional da comunicação organizacional, mas, principalmente, mostra-se também como legitimadora da produção de conhecimento da área em questão. A revista Comunicação Empresarial publicada pela associação apresentou-se como um corpus de análise bastante interessante quando o intuito é revelar a voz institucional da ABERJE. A razão do periódico representar a voz institucional da associação está diretamente ligada à própria seleção de temas e abordagens de seus textos no caso veículo "revista". E, embora a revista como tal apresente hipotéticas características de isenção e neutralidade frente aos pontos discutidos nos textos que a compõe, o tratamento das matérias do modo como se organizam e se intitulam não se desvinculam à própria voz institucional da ABERJE. Optou-se, diante disso, por utilizar as edições deste periódico como um documento pertinente ao propósito desta dissertação.

\subsection{A força representativa da ABERJE}

A ABERJE apresenta-se, hoje, como a associação com mais força institucional frente aos interessados em comunicação organizacional no Brasil. Com mais de quarenta anos de vida e aproximadamente mil organizações ${ }^{42}$ associadas a ela, em nível nacional, esta associação é bastante conhecida por profissionais e acadêmicos.

Foi fundada por um grupo de profissionais de comunicação, liderado por Nilo Luchetti, gerente da empresa Pirelli na ocasião, com o principal propósito de aprimorar a produção das publicações empresariais para funcionários, especialmente jornais e revistas. Naquele momento, havia a percepção que tais publicações eram produzidas de maneira amadora, não trazendo resultados eficientes para as organizações. Assim, percebeu-se a necessidade de profissionalizá-las e para apoiar esta atitude, surgiu a ABERJE, inicialmente intitulada como Associação Brasileira de Editores de Revistas e Jornais de Empresa. Torquato (1984, p.28) nos ajuda a compreender o contexto:

\footnotetext{
${ }^{42}$ Os associados da ABERJE são organizações privadas, públicas e do Terceiro Setor. Mas, conforme o estatuto da ABERJE, pessoas físicas também podem se associar a ela, desde que colaborem para o desenvolvimento da comunicação organizacional no país.
} 
"Na época de sua criação, reinava completa improvisação. Funcionários de escalões inferiores reuniam-se para fazer o jornal ou o boletim, escreviam eles próprios os textos, faziam os desenhos, ajeitavam de qualquer maneira a forma gráfica da publicação, datilografavam tudo e realizavam até o trabalho de impressão em mimeógrafos. Muitas publicações já morriam no nascedouro, condenadas pela indefinição de objetivos, pelo amadorismo e pelo completo desconhecimento técnico de seus planejadores."

A idéia de criar a associação partiu de Nillo Luchetti, inspirado por experiências deste tipo que conhecera na Itália, sua terra natal. Após conseguir o apoio de outros executivos de grandes empresas da região do ABC, como, por exemplo, General Motors, Alcan e General Eletric, Luchetti promoveu uma convenção nacional para informar outros profissionais de comunicação sobre a idéia de formar a associação. O evento ocorreu em 08 de outubro de 1967, em São Paulo, com a participação de representantes de 52 publicações de empresas, sendo ali criada a ABERJE.

O principal objetivo da associação recém-criada apoiava-se em convencer as empresas em produzir publicações com mais qualidade e com a responsabilidade de profissionais de comunicação. Nassar (2006c), professor da ECA- USP e Diretor-Geral da ABERJE na atualidade, apresenta uma visão diferenciada do principal propósito da associação nesta época. Não nega que a idéia centrava-se na questão da melhoria dos tipos de publicações empresariais, porém, ressalta que isso era defendido para se alcançar o verdadeiro propósito da ABERJE: humanizar os processos comunicacionais nas empresas. Afirma que "na época, na maioria das empresas brasileiras, os jornais e revistas fabris, eram basicamente repositórios mal feitos de notícias oficiais, da administração, destinados a louvar a alta direção ou os acontecimentos governamentais." (NASSAR, 2006c, p.241). O autor ressalta que a associação foi fundada com base nas "Relações Humanas" ${ }^{43}$, orientação que, coincidentemente ou não, também guiava as ações do IDORT nas décadas de 1950 e 1960.

Na década de 1970, após a fundação da ABERJE, observaram-se maior investimento das empresas na produção de publicações empresariais (boletins, jornais,

\footnotetext{
${ }^{43}$ Este aspecto, aliás, mereceria uma análise mais aprofundada, visto que existem diversas críticas de correntes de pensamento da sociologia do trabalho contrárias ao caráter positivo que Nassar (2006c) atribui à Escola de Relações Humanas. O aspecto "humanizador" desta abordagem da administração não necessariamente contrariou os preceitos do Taylorismo e, sim, tentou contribuir para as gerências ajustarem o trabalhador ao modo de produção das empresas (BRAVERMAN, 1987). Portanto, talvez, não seja interessante exaltar que a ABERJE originou-se com base nos ideais da "Escola de Relações Humanas". Seria um equívoco afirmar que estes possibilitaram ao trabalhador melhores condições nas empresas que o próprio taylorismo.
} 
revistas) e um crescimento na contratação de profissionais de comunicação, especialmente de jornalistas, por diversas organizações. O foco principal da associação na produção destes veículos de comunicação perdurou na década de 1970 e início dos anos 1980, quando seus interesses começaram a se modificar em prol do desenvolvimento de planos de comunicação mais abrangentes para as empresas.

Kunsch (1997) e Nassar (2001) afirmam que a ABERJE comporta historicamente duas fases: 1967 a 1983 e 1983 em diante, destacando a década de 1980 como um divisor de águas da comunicação organizacional no Brasil. Este primeiro período, da época de fundação da ABERJE até 1983, quando as diretorias da associação foram renovadas, foi marcado pela preocupação de melhoria técnica de produção das publicações empresariais voltadas para os funcionários. Já, a partir de 1983 em diante, a ABERJE fortalece suas atividades e abraça outras frentes da comunicação organizacional, além das publicações empresariais. É nesta época que se inicia a modernização da associação, sendo um dos indícios disto a modificação de seu estatuto em 1989 e de sua própria razão social para "Associação Brasileira de Comunicação Empresarial” ${ }^{44}$. Várias são as decisões tomadas para alcançar os novos objetivos orientados pela intenção principal de convencer o empresariado dos importantes resultados econômicos que as estratégias de comunicação poderiam trazer para as organizações. Uma destas decisões refere-se à expansão regional da ABERJE com a formação do grupo de associados do Estado do Rio de Janeiro.

Hoje, a ABERJE conta com dez núcleos de comunicação empresarial (Amazonas, Bahia, Cidade de São Paulo, Espírito Santo, Minas Gerais, Paraná, Rio de Janeiro, Rio Grande do Sul, São Paulo - interior, Santa Catarina), intitulados "capítulos regionais" ${ }^{45}$, cujos diretores são executivos de comunicação de diversas organizações brasileiras como: Petrobras, Embraco, Grupo Gerdau, Companhia Vale do Rio Doce, Odebrecht, CPFL Energia, dentre outras.

Ainda na década de 1990, a ABERJE cria a Revista Brasileira de Comunicação Empresarial $^{16}$ e intensifica a promoção de eventos nacionais e internacionais aos seus associados com o propósito de debater questões relacionadas principalmente à dimensão

\footnotetext{
${ }^{44}$ Desde o final dos anos 1990, busca também disseminar a denominação "Associação Brasileira de Comunicação Organizacional”.

${ }^{45}$ Informação acessada no site da ABERJE. Disponível em: <www. aberje.com.br>. Acesso em: 20 out. 2009.

${ }^{46}$ Criada em 1991 e hoje nomeada como Comunicação Empresarial. Para efeito de análise, neste trabalho utilizaremos a denominação mais recente. Para mais informações, veja o "Quadro Descritivo" no apêndice deste trabalho.
} 
estratégica da comunicação organizacional. Diversos cursos, congressos, fóruns são criados com esta intenção. Parcerias com associações estrangeiras de mesma natureza (como, por exemplo, a IABC - International Association of Business Comunicators) também começaram a ser estabelecidas, fazendo parte do projeto de internacionalização da ABERJE ${ }^{47}$.

Nos anos 1990, a ABERJE desenvolve suas ações com a intenção de ser vista como propulsora do avanço da comunicação empresarial no Brasil, incentivando e concretizando meios para solidificar o perfil deste campo como área estratégica de resultados, agregando valor econômico às empresas. Intensifica-se, dessa forma, o esforço da associação em convencer os empresários a investir financeiramente em comunicação nas organizações. $\mathrm{O}$ discurso da ABERJE, mais do que nunca, reafirma o entendimento de comunicação como ferramenta estratégica útil para o bom funcionamento das organizações, tanto no seu ambiente interno como em sua interação com o mundo externo. Neste contexto, ao profissional de comunicação são exigidas outras qualidades e competências além da habilidade técnica em produzir publicações empresariais ou releases. Cabe a ele, agora, conforme o entendimento da ABERJE, ser um estrategista, consultor e possível gerenciador de conflitos, com formação abrangente, polivalente e conhecimento total sobre a organização em que trabalha.

A associação mostra-se preocupada em estar em compasso com as transformações do mundo empresarial e suas necessidades. Globalização de mercados, cidadania empresarial, paradigmas da qualidade total, excelência gerencial e perfil do consumidor são alguns dos assuntos que integram as pautas de discussão da ABERJE, especialmente desde a década de 1990.

$\mathrm{Na}$ primeira década deste século, a ABERJE reforça ainda mais seu caráter educador, conseguindo inserção no meio acadêmico ao apoiar eventos realizados para cursos de graduação e pós-graduação de universidade brasileiras privadas e públicas, como é o caso da Universidade de São Paulo. Nassar (2006a) destaca que a vocação da ABERJE é educar os interessados em comunicação organizacional. Para tanto, a associação promove eventos e

\footnotetext{
${ }^{47}$ Muitas outras associações mantêm parcerias com a ABERJE hoje. Veja, por exemplo: a APCE - Associação Portuguesa de Comunicação de Empresa (criou com a ABERJE uma outra associação chamada de ACELP Associação de Comunicação Empresarial de Língua Portuguesa); a Apimec - Associação de Profissionais Investidores do Mercado de Capitais; o Ibase - Instituto Brasileiro de Análises Sociais e Econômicas; o ETHOS Instituto Ethos de Responsabilidade Social; a ABRH - Associação Brasileira de Recursos Humanos, que promove anualmente com a ABERJE o Congresso Nacional de Comunicação e Recursos Humanos, desde 2003. A ABERJE também tem apoiado institucionalmente várias ações de outras entidades brasileiras da área de comunicação, como por exemplo, a INTERCOM - Sociedade Brasileira de Estudos Interdisciplinares da Comunicação e a ABRAPCORP - Associação Brasileira de Pesquisadores de Comunicação Organizacional e de Relações Públicas.
} 
cursos sobre diversos temas que compõem a área da comunicação organizacional, ministrados por doutores, mestres, especialistas e profissionais nacionais e estrangeiros ${ }^{48}$.

\section{Fontes de informação da ABERJE}

O fortalecimento institucional da ABERJE e seu teor educacional são ainda exaltados por meio de dois documentos produzidos por seus Conselhos e sua diretoria em 2004, os quais repensam a visão, a missão, os valores e as orientações de gestão estratégica defendidas pela associação. Conhecidos como "Carta de São Paulo" e "Carta de Ouro Preto", tais documentos criados, respectivamente, em julho e agosto de 2004, reforçam sua compreensão de comunicação organizacional pautada pela dimensão estratégica. A missão da associação de "articular, organizar e compartilhar o conhecimento em comunicação produzido pela sociedade, fomentar práticas de vanguarda na gestão estratégica e fortalecer os relacionamentos das organizações"49 explicita claramente o caminho escolhido pela entidade. Em comemoração aos seus 40 anos de existência, a associação publicou em 2007 um outro documento, nomeado "A comunicação organizacional frente ao seu tempo: missão, visão e valores da ABERJE"50, em que reafirma seus preceitos e reelabora suas diretrizes ${ }^{51}$.

Nesta mesma época foi criado o Centro de Memória e Referência ABERJE (CMR), cujo acervo inclui diversos documentos institucionais da própria associação (materiais de seus cursos, casos do Prêmio ABERJE, as edições de sua revista, etc.), bem como publicações empresariais e outros tipos de materiais de comunicação de seus associados. O CMR é aberto à

\footnotetext{
${ }^{48}$ Desde 2005, a ABERJE criou uma parceria com a Syracuse University de Nova York para a realização do "Curso Internacional de Comunicação”. Ministrado inteiramente por instrutores norte-americanos no Brasil, o curso tem como foco as questões gerenciais e estratégicas da comunicação nas organizações.

${ }^{49}$ Trecho retirado da "Carta de Ouro Preto" publicada na edição de n.58 da revista Comunicação Empresarial.

${ }^{50}$ Este documento foi escrito por três pessoas representativas da associação na atualidade: Paulo Nassar, professor da ECA-USP e Diretor-Geral da ABERJE, Renato Janine Ribeiro, conselheiro da ABERJE, professor titular da Universidade de São Paulo e ex-diretor de Avaliação da Coordenadoria de Aperfeiçoamento de Pessoal de Nível Superior - CAPES e Rodolfo Witzig Guttilla, presidente do conselho deliberativo da ABERJE e diretor de Assuntos Corporativos e Relações Governamentais da Natura Cosméticos.

${ }^{51}$ Visão: "Ser o centro de referência na produção e disseminação de conhecimento e práticas de Comunicação e Relacionamento inspirando as organizações em suas estratégias de gestão"; missão: "Articular a Comunicação das organizações por meio de iniciativas em Educação, Gestão do Conhecimento, Reconhecimento e Relacionamento, produzindo e compartilhando saber, disseminando as melhores práticas e fortalecendo o papel estratégico do comunicador"; valores: “ética, inovação, pluralidade e humanismo”. Para mais informações, ver o documento na íntegra: Nassar; Ribeiro; Gutilla (2007).
} 
visitação pública, prestando serviços de atendimento à pesquisa, consulta do acervo e visitas técnicas aos interessados em montar centros de memória.

As dezenas de eventos anuais promovidas pela associação representam sua forte atuação "educacional” na área da comunicação organizacional. Mas não encerram a atuação da ABERJE. Dentre outras ações que completam a sua inserção nos campos profissional e acadêmico da comunicação organizacional constam: a produção de um site que mantém há mais de dez anos e a promoção anual do Prêmio ABERJE (com o propósito de premiar ações de comunicação empresarial desenvolvidas por profissionais de organizações associadas), este com mais de três décadas de existência.

Os associados recebem a revista Comunicação Empresarial e um boletim eletrônico quinzenal intitulado "Ação ABERJE”. Também, têm direito a descontos especiais nos eventos e cursos promovidos pela associação, além de poder participar de seus grupos de estudos. "Grupo de Relações Públicas" e "Grupo de Imprensa" são alguns dos grupos de estudos que a ABERJE criou para propiciar um espaço de discussão entre seus associados de temas de interesse em comunicação organizacional. Nestas ocasiões, são proferidas palestras de profissionais de comunicação que trabalham em organizações associadas à ABERJE.

A associação também desenvolve pesquisas utilizando-se do Instituto ABERJE de Pesquisas - DatABERJE. No que tange o tema "comunicação interna”, já foram realizadas três pesquisas nos anos de 2002, 2005 e 2007 com o propósito de mapear as práticas de comunicação interna em organizações brasileiras.

Num primeiro momento da elaboração dessa dissertação de mestrado, todas essas fontes de informação foram investigadas por nós, ganhando destaque as publicações: livros e revista.

\section{Coleção "Comunicação interna: a força das empresas"}

Além de realizar todas as atividades citadas anteriormente, a associação edita e publica livros por meio da ABERJE Editorial. Trata-se de títulos que discutem assuntos diretamente relacionados à comunicação organizacional. Relações públicas, memória empresarial, estratégias comunicacionais de empresas, mensuração e pesquisa são alguns dos 
temas que norteiam as obras. Ganha destaque, neste rol de opções, a coleção de livros escritos com o interesse no tema "comunicação interna".

Intitulada de "Comunicação interna: a força das empresas", esta coleção integra quatro volumes, até o momento, publicados, respectivamente, em 2003, 2005, 2006 e 2008. Estes livros ${ }^{52}$ são utilizados em cursos de graduação de diversas universidades brasileiras como bibliografia em disciplinas que tratam sobre comunicação organizacional.

O conteúdo de todos os volumes é inspirado nas palestras ministradas em edições do evento "Mix ABERJE de Comunicação Interna e Integrada", promovido periodicamente pela associação. Os autores destes livros são, em grande parte, profissionais brasileiros atuantes na área de comunicação em organizações nacionais e multinacionais. Ocupam cargos de gestores, como diretores e gerentes, tendo formações acadêmicas diversas (em jornalismo, relações públicas, publicidade e propaganda, marketing, letras, história, psicologia etc.).

Tais publicações, no geral, são constituídas por relatos de experiências de estratégias desenvolvidas por estes profissionais que lidam com a gestão da comunicação em organizações, especialmente as que são associadas à ABERJE. São textos escritos pelos próprios gestores, discorrendo sobre casos de sucesso, com o propósito de legitimação de reprodução de suas práticas e, conseqüentemente, dos próprios preceitos da ABERJE. São diversas as empresas representadas nas falas dos autores. Fiat do Brasil, Companhia Siderúrgica Nacional - CSN, DaimlerChrysler Brasil, Natura, Votorantim, Petrobras, Vivo, Banco Itaú, Gerdau Açominas, Odebrecht, Acesita S.A, Vale, General Motors do Brasil, SABESP, AMBEV, ACCOR, Aracruz Celulose, Claro são alguns exemplos de organizações cujas práticas de comunicação são discorridas nos textos. Muitas delas, por sinal, foram premiadas pelo Prêmio ABERJE.

As temáticas abordadas nestes livros são relacionadas diretamente à gestão dos processos de comunicação interna, sendo que em cada volume há peso maior para algumas temáticas específicas. O primeiro volume, por exemplo, é inteiramente organizado a partir dos seguintes eixos temáticos: produção de mensagens direcionadas aos funcionários, comando dos processos de comunicação interna, a comunicação interna nas mudanças organizacionais e gestão de crises empresariais. Vários são os textos escritos a partir destes eixos temáticos. Já o

${ }^{52}$ Estamos nos referindo especificamente aos seguintes livros: NASSAR, Paulo. (Org.). Comunicação Interna: a força das empresas. v.1. São Paulo: ABERJE Editorial, 2003; NASSAR, Paulo. (Org.). Comunicação Interna: a força das empresas. v.2. São Paulo: ABERJE Editorial, 2005b; NASSAR, Paulo. (Org.). Comunicação Interna: a força das empresas. v.3. São Paulo: ABERJE Editorial, 2006b; NASSAR, Paulo. (Org.). Comunicação Interna: a força das empresas. v.4. São Paulo: ABERJE Editorial, $2008 \mathrm{~b}$. 
segundo volume da coleção traz textos que tratam sobre assuntos como: lançamento de marcas de produtos aos funcionários, criação de uma identidade organizacional única frente aos funcionários, busca pela integração (criação de espírito de equipe) entre funcionários, alinhamento dos processos comunicativos aos objetivos da gestão organizacional, pesquisa como instrumento de avaliação e mensuração da comunicação interna, a relação entre cultura organizacional e comunicação interna, envolvimento das famílias dos empregados na vida da empresa.

É interessante notar a forte preocupação dos autores destes dois primeiros volumes em enfatizar as ferramentas e os instrumentos de comunicação utilizados nos casos práticos relatados, bem como os resultados alcançados com estas experiências.

O terceiro volume mostra o interesse por certos aspectos da comunicação interna: exaltação do empregado como cidadão, a influência da psicologia na comunicação interna, o tratamento em relação aos funcionários como parceiros da empresa, o jornal interno e a intranet como ferramentas estratégicas de comunicação.

Observarmos que o quarto e mais recente volume da coleção traz uma marcante característica que o diferencia, em certa medida, dos títulos anteriores. Ele se detem menos aos relatos de casos práticos de empresas. Os textos são escritos com foco maior em discutir certos temas a partir de referências bibliográficas apreendidas pelos autores, mesclando informações adquiridas por meio dessas leituras com as idéias oriundas de suas próprias experiências de mercado. Em todos os títulos desta coleção é possível encontrarmos artigos de pesquisadores e professores de universidades, mas neste último volume observamos uma maior presença de acadêmicos discutindo temas como: comunicação digital, lideranças nos processos de comunicação interna, responsabilidade social, ética e transparência na comunicação organizacional. Tema, este, aliás, discutido pelo conhecido professor de filosofia da Universidade de São Paulo, Renato Janine Ribeiro.

Assim como a revista Comunicação Empresarial, os quatro livros da coleção "Comunicação interna: a força das empresas" buscam legitimar o seu papel influenciador na formação do campo brasileiro da comunicação organizacional, buscando mediar os seus lados acadêmico e profissional. Inclusive, eles poderiam ter sido escolhidos como objeto para analisarmos o entendimento que a ABERJE tem sobre as relações entre trabalhadores e organizações. No entanto, a revista Comunicação Empresarial mostrou-se uma opção mais sólida para a reflexão que nos propomos a desenvolver, como veremos mais à frente. 
Discorrer sobre estes livros, bem como sobre outras atividades desenvolvidas pela ABERJE, neste momento, nos ajudou a demonstrar o grande destaque desta associação no cenário brasileiro da comunicação organizacional. O propósito aqui foi de mostrar a face institucional desta associação: suas políticas e diretrizes corporativas. Ao descrever as ações realizadas por ela, houve a intenção de apontar o seu poder de intervenção no desenvolvimento do campo da comunicação organizacional no Brasil.

\subsection{Estudo da comunicação interna na revista Comunicação Empresarial publicada pela ABERJE}

\subsubsection{A opção pela revista Comunicação Empresarial}

Para a análise de como a ABERJE tem tratado as relações entre trabalhadores e organizações por meio da comunicação, optou-se por uma leitura crítica da revista Comunicação Empresarial - periódico editado e publicado pela associação. A revista é trimestral e distribuída no formato impresso nacionalmente para todos os mais de mil associados da ABERJE; além disso, ela também está disponível eletronicamente no site da associação. Os textos analisados representam o conjunto de 65 edições. Hoje conhecido como apenas Comunicação Empresarial, este periódico, até a edição de n. 58 (2006), era denominado Revista Brasileira de Comunicação Empresarial.

O período analisado inicia-se em 1991, ano de publicação do primeiro número da revista, e termina no último trimestre de 2007. A nosso ver, tal recorte temporal é significativo para a análise proposta, visto que coincide com importantes mudanças no mundo do trabalho nesta década e meia, as quais se refletem nos processos comunicativos organizacionais contemporâneos. A revista segue as transformações do sistema produtivo que mais impactaram as organizações brasileiras neste período, apropriando-se deste conhecimento para pensar a comunicação organizacional com base na dimensão estratégica.

Intencionalmente, separamos os textos da revista referentes às discussões sobre comunicação interna, sendo importante esclarecer que não existe uma distinção, de nossa 
parte, dos autores das matérias, das reportagens e dos artigos dos números da publicação analisados. Conforme nossa interpretação, como se verá adiante, as vozes da revista representam a homogeneidade de um mesmo discurso; não se apresentam como vozes dissonantes que confrontam visões ideológicas diferentes. Nesse panorama, importa menos o gênero textual enquadrado do que a voz aglutinadora de um discurso hegemônico da ABERJE que constitui os textos destes respectivos gêneros. Isso explica porque não levaremos em consideração, de forma contundente, na análise deste corpus da pesquisa, se os autores dos textos publicados na revista são integrantes da equipe de redação do próprio veículo ou se são pessoas externas à ABERJE, como entrevistados e articulistas, por exemplo. Mesmo que a revista tente se isentar da responsabilidade do teor das discussões e idéias destes autores, é perceptível o alinhamento do pensamento destes quanto aos preceitos da ABERJE. É possível observar, aliás, a não incorporação de fontes questionadoras do discurso da associação na revista. Não há contra-voz ou contra-discurso, como se verá à frente.

No quadro descritivo, disponível no apêndice desta dissertação, estão indicados os textos separados para a leitura crítica da revista Comunicação Empresarial. Vale lembrar, mais uma vez, que estes foram escolhidos a partir do critério de relação direta com o assunto "comunicação interna".

\subsubsection{Análise da revista Comunicação Empresarial}

No decorrer das investigações sobre o campo de estudos da sociologia do trabalho (expostas no capítulo III) observou-se a manifestação de quatro temas que também são abarcados pelas discussões que a própria área da comunicação organizacional, mais especificamente da comunicação interna, tem feito sobre as relações entre trabalhadores e organizações. Nossa intenção aqui é entender como a ABERJE tem tratado tais temas em sua revista.

Certamente, o tema mais recorrente e representativo tem sido a tentativa de incorporação do trabalhador à racionalidade da organização. A mobilização do trabalhador em prol dos objetivos organizacionais por meio de estratégias de comunicação mostra-se como elemento norteador do entendimento da comunicação nas relações de trabalho sob a ótica da 
comunicação organizacional no Brasil. Deste modo, os aspectos que caracterizam este item, por sinal com uma gama variada, estão presentes no conjunto de textos do periódico analisado. Dentre os principais podemos destacar: a consonância entre as formas de gestão organizacional e o tratamento da comunicação; a relação direta entre comunicação e aumento da produtividade da empresa; a grande atenção dada à disseminação das diretrizes da organização aos empregados.

Acessibilidade à informação, segundo tema pensado para a análise, mostra conformidade à busca de imbuir o trabalhador à racionalidade da empresa e apresenta-se como um fator preponderante na discussão aqui proposta. Criar formas que possibilitem ao empregado saber sobre informações que contribuam para o melhor desenvolvimento de suas tarefas no trabalho e para que possa conhecer mais sobre os preceitos da organização tem sido um dos focos importantes quanto ao tratamento da comunicação. $O$ interesse das organizações com o fluxo de informação e com os veículos de comunicação direcionados aos trabalhadores ganha grande destaque neste contexto.

Por fim, os dois outros temas considerados essenciais para a análise são os que evidenciam a valorização do trabalhador como pessoa e a sua individualização nas relações de trabalho. Existe grande interesse das organizações em expor a sua suposta face humana para o trabalhador. A tentativa de convencê-lo sobre a importância de sua opinião no ambiente de trabalho e a busca em demonstrar certa preocupação com a qualidade de vida de seus funcionários não deixam, também, de fazer parte de suas estratégias de comunicação, um receituário repetido nos textos da revista Comunicação Empresarial, como veremos mais à frente. É nítido, além disso, o interesse das organizações quanto à vida do trabalhador fora do ambiente de trabalho, seja em suas relações com a família ou com o lazer. Sem exageros, é possível afirmar que estas estratégias de comunicação interna são planejadas em concordância com o interesse da empresa em individualizar o trabalhador em face de uma força coletiva que poderia contrapor-se aos objetivos organizacionais. Sob esta égide, não raramente é possível encontrar aspectos como: responsabilização individual pelo trabalho a ser desenvolvido e por sua melhoria, potencialidade das qualidades individuais do trabalhador e suas competências como profissional.

Sigamos com as análises das edições da revista da ABERJE escolhidas para a discussão destes temas quanto ao tratamento da comunicação nas relações de trabalho. 


\subsubsection{Revista Comunicação Empresarial}

\section{Incorporação do trabalhador à racionalidade da organização}

As discussões ao longo desta dissertação nos mostram que os estudos brasileiros de comunicação organizacional apresentam como foco principal a sua dimensão estratégica. E os textos da revista Comunicação Empresarial aqui analisados mostram grande conformidade com esta mesma linha de pensamento.

A dimensão estratégica exige um alinhamento dos processos comunicacionais aos negócios da organização e à sua maneira de agir. Sob este viés, observa-se claramente a tentativa contínua de moldar a comunicação às necessidades das formas de gestão produtiva das empresas. Os textos publicados nas edições produzidas na década de 1990 discutem as transformações que as empresas brasileiras instituíram em suas administrações - espelhadas em grande parte nos preceitos do toyotismo. Mudanças, diga-se de passagem, que, de uma forma ou de outra, ocorreram com o respaldo de estratégias de comunicação. Reestruturação dos níveis hierárquicos com a redução destes; enxugamento de departamentos e de áreas; descentralização da tomada de decisões, políticas de contenção de custos e intensificação na busca por maior produtividade e rentabilidade são significativos exemplos das alterações nos sistemas de gestão das organizações brasileiras, conforme apontou o periódico analisado.

Neste contexto, o engajamento do trabalhador aos princípios e preceitos da organização em que atua aparece como elemento central nas estratégias de comunicação interna. Exemplo disso refere-se à relação que se observa entre comunicação e a implantação dos programas de qualidade total nas organizações, as quais objetivam conquistar maior competitividade no mercado com base na excelência na prestação de serviços e do aumento da produtividade acompanhados da racionalização de custos. Para tanto, compreendem a comunicação como ferramenta indispensável:

“(...) agora também no Brasil, é cada vez maior o número de empresas mobilizadas na busca incessante da qualidade em produtos e serviços, em todas as ramificações da cadeia produtiva. E uma coisa essas organizações já 
podem dar como favas contadas: a comunicação interna é um decisivo aliado dos programas de qualidade total." (Parceria indispensável, n.12, 1994) ). $^{53}$.

Deve-se notar que, segundo este discurso, é grande a preocupação das empresas em conseguir a cumplicidade dos funcionários às suas determinações e a revista traz para o leitor casos que relatam as experiências de sucesso que determinadas organizações (a maioria delas são associadas da ABERJE) têm conseguido com a utilização de estratégias de comunicação interna. Estratégias, estas, calcadas na produção de mensagens claras, objetivas, com transmissão dos valores organizacionais e esclarecimento sobre os negócios da empresa, como está representado na fala de um executivo de determinado banco:

“(...) quem executa todo o trabalho são os funcionários do banco. Eles precisam não só conhecer bem os produtos e serviços como também o caminho que o banco quer trilhar, seus objetivos, a visão que a empresa tem de seu posicionamento no mercado e o porquê de certos movimentos estratégicos da organização. Esta é a visão que nos leva a buscar um forte aprimoramento na comunicação interna (...).” (O segredo do negócio, n.11, 1994).

Com a atenção das organizações voltada para a eficiência dos programas de qualidade total - destaque na revista especialmente na década de 1990 -, aos funcionários é exigida uma atitude de excelência na prestação de serviços e no atendimento ao cliente. Para tanto, são persuadidos a agir como se eles próprios fossem os clientes da empresa em que trabalham. Considerados, dessa forma, como "clientes internos", os trabalhadores são incentivados pelas gerências a conhecer os processos de desenvolvimento de produtos e serviços, bem como os procedimentos e funcionamento de boa parte dos setores da organização a fim deles próprios cobrarem a qualidade daquilo que é oferecido aos clientes externos ou consumidores. Nesta mesma lógica, o empregado é motivado a tratar os departamentos e demais funcionários da empresa como seus possíveis "clientes", sendo pressionado, de alguma forma, pelos próprios colegas do ambiente de trabalho a desempenhar

\footnotetext{
${ }^{53}$ Resolvemos elencar, ao longo de todo este texto, as seguintes informações dos exemplares da revista como referência, nesta ordem: título da matéria, número de edição e ano. As demais informações, por considerarmos dispensáveis para a compreensão desta análise, resolvemos colocá-las no quadro descritivo, no apêndice desta dissertação.
} 
muito bem suas tarefas para contribuir com o bom funcionamento de todos os setores organizacionais e não somente com o departamento em que está alocado.

Esta concepção de relacionamento entre organização e trabalhadores é geralmente expressada na literatura de comunicação organizacional como "endomarketing". Alguns estudiosos fazem questão de deixar bem clara a distinção entre o conceito desta terminologia e o entendimento de "comunicação interna". Kunsch (2003b), por exemplo, defende a idéia de que a comunicação interna trata o funcionário como um indivíduo que constrói relações muito mais próximas das organizações, auxiliando-as na consecução de seus objetivos mais abrangentes, os quais extrapolam a excelência no atendimento ao cliente ou consumidor, enquanto que o "endomarketing" apóia-se exclusivamente neste último propósito. Esta tentativa de diferenciação, entretanto, reflete, tanto em um, como em outro, a prioridade em pensar a dimensão estratégica da comunicação sem abordar as reais condições do trabalhador no ambiente de trabalho interno às organizações.

A retórica da comunicação interna preocupa-se em convencer o trabalhador - e, inclusive, os gestores - que ele é considerado como cidadão pelas organizações a partir do momento que estas o tratam não mais como um subserviente e, sim, numa condição de agente das mudanças necessárias. A título de exemplificação, destacamos um trecho de uma entrevista realizada pela revista com determinado representante da alta administração de um banco privado:

"Estimular a comunicação de qualidade com os funcionários implica dizer que o banco quer considerá-los mais como parceiros do que propriamente funcionários?

Sem dúvida. Uma de nossas macroestratégias é a gestão participativa, e isto se enquadra na gestão participativa. Se quero que eles participem ativamente do processo não apenas executando ordens, eles precisam conhecer onde queremos chegar e como queremos chegar. A parceria é decorrência da visão estratégica de administração participativa e a comunicação é a maneira de ativar essa parceria." (O segredo do negócio, n.11, 1994).

Referir-se ao funcionário como "parceiro" da organização faz parte de uma postura inspirada nas relações públicas (MESTIERI, 2004) e mostra-se bastante presente no discurso da comunicação interna. A "parceria" entre a organização e o trabalhador aparece, sob este viés, como uma possibilidade de comprometimento de interesses entre ambos. Por outro lado, um olhar mais crítico sobre a questão diria que isto pode ser mais uma das 
estratégias das empresas em mobilizar o trabalhador a favor de seus ideais, suprimindo a evidência de qualquer tipo de conflitos de interesses existentes. Até mesmo porque, ao tratar o trabalhador como "parceiro", "colaborador" ou "cliente", o discurso da comunicação interna, em concordância com os interesses empresariais, procura descaracterizá-lo de sua condição de classe.

Nesta mesma direção, incentiva-se que haja coesão no ambiente organizacional, onde o trabalho em equipe deve ser valorizado. A implantação da gestão pela qualidade total começou a exigir dos trabalhadores conhecimento sobre as funções e tarefas que os demais funcionários exercem na empresa. Especialmente aqueles que participam da mesma área ou departamento são induzidos a compartilhar informações a respeito de suas atividades profissionais. O discurso deste tipo de gestão acredita que tal compartilhamento é importante para que o trabalho em equipe seja bem desenvolvido. O desempenho de um funcionário agrega valor ao desempenho de outros.

Integrar os funcionários, ou seja, criar o que se denominou espírito de equipe, tem sido outro aspecto que permeia as discussões sobre comunicação interna na revista, especialmente nos textos que tratam sobre os programas de qualidade total, na década de 1990. Aspecto este, vale ressaltar, que tem sido, até hoje, foco de atenção das estratégias de comunicação direcionadas aos trabalhadores em seus ambientes de trabalho. Em uma das matérias publicadas, determinado consultor da área de qualidade dá seu depoimento sobre a conduta desejável das pessoas que são empregadas nas empresas: "Elas devem estar com a cabeça feita, convencidas do programa, lutando, brigando e acreditando na qualidade.” (Parceria indispensável, n. 12, 1994). E o redator da matéria complementa:

"É então que a comunicação interna entra no circuito, já que, para a viabilização participativa - um dos pressupostos da qualidade -, os funcionários precisam estar informados sobre o que acontece no seu local de trabalho. Só assim eles estarão motivados a colaborar na busca da excelência." (Parceria indispensável, n. 12, 1994).

A "viabilização participativa", indicada no trecho acima, é representada pelo o que se costuma chamar no meio empresarial de "gestão participativa". A retórica da comunicação interna busca legitimar este tipo de gestão quando anuncia que ao funcionário é dada a possibilidade de interferir no processo da realização do trabalho por meio de emissão de 
opiniões, sugestões e compartilhamento de informações, tornando, assim, suas atividades mais aprazíveis e interessantes para si próprio. Por outro lado, sabemos que a "gestão participativa" oferecida pelas organizações aos empregados não necessariamente os presenteiam com o direito de opinar livremente tanto sobre fatores que consideram negativos para a realização de seu trabalho como quanto às atitudes das chefias e da própria empresa. Considera-se, na verdade, como "gestão participativa" aquela que motiva o trabalhador a pensar e refletir sobre problemas referentes exclusivamente à gestão da produção. Pois, sob o viés de alguns estudiosos da sociologia do trabalho, enquanto os funcionários ocupam-se com este tipo de preocupação, isto é, no momento que sua capacidade intelectual é direcionada para este fim, as possibilidades de questionamento sobre as condições de trabalho são minimizadas (LIMA, 2006).

Diante desta perspectiva, é perceptível a importância que se ao trabalhador em conhecer o negócio da empresa e perceber que é solicitado a contribuir para o seu desenvolvimento, independente de sua função ou cargo. Até mesmo porque, a empresa sabe que quando a organização e trabalhadores juntam-se em prol de um mesmo objetivo - como, por exemplo, o alcance da "qualidade total" - a idéia de consenso e harmonia no ambiente de trabalho manifesta-se fortemente. Deste modo, as organizações apóiam-se nas estratégias de comunicação interna para disseminar os aspectos de sua cultura e convencer os funcionários a compartilhar dos mesmos objetivos que os dela. Eventos, publicações (como jornais, revistas, boletins), intranet, campanhas de conscientização são alguns exemplos das diversas estratégias de comunicação interna utilizadas pelas empresas na tentativa de incorporação do trabalhador à racionalidade organizacional. Em acordo com o discurso da alta administração - suas formas de gestão - e com as políticas de recursos humanos, a comunicação interna tem sido interpretada como uma ferramenta estratégica útil à organização na tentativa de envolver os funcionários em prol de seu êxito:

"Nesse contexto, emerge com clareza o novo papel desempenhado pela Comunicação Empresarial: o de contribuir para a consecução das metas de sobrevivência das empresas, atuando como facilitadora do trabalho conduzido pela direção (que tem a decisão estratégica sobre os rumos das operações) e pelas gerências (que conduzem o trabalho das pessoas que farão a organização alcançar metas previstas).” (Por uma comunicação de qualidade, n.18, 1996). 
Conceber a comunicação como apoio às ações e políticas gerenciais está diretamente ligado ao conceito de comunicação interna explicitado na revista Comunicação Empresarial. Coerentemente com o discurso da dimensão estratégica da comunicação, o teor do trecho anterior, expõe claramente a idéia de comunicação como ferramenta de controle e condução dos processos administrativos e produtivos em organizações. À gerência da empresa é atribuída a responsabilidade por instruir os trabalhadores e tentar manter um bom relacionamento entre estes e a organização.

Não esqueçamos que os gerentes também são alvos da tentativa de mobilização da subjetividade ou inteligência no trabalho. Na busca pelo objetivo organizacional, eles precisam incorporar o discurso institucional da empresa para, então, comportar-se como um representante dela frente ao corpo de funcionários. Para tanto, Dejours (2007) afirma que as empresas utilizam uma estratégia específica. Nomeada pelo autor de "estratégia da distorção comunicacional”, esta é baseada na produção de informações falsificadas transmitidas às gerências por parte da mais alta cúpula administrativa:

"A estratégia da distorção comunicacional é uma estratégia cuja iniciativa parte do alto da hierarquia e que arrigimenta, por camadas sucessivas, os níveis inferiores. Pode-se caracterizá-lo como a adoção de um sistema de produção e de controle de práticas discursivas referentes ao trabalho, à gestão e ao funcionamento da organização.” (DEJOURS, 2007, p.59).

O autor acredita que os gerentes sabem, melhor do que ninguém na organização, a existência de numerosas falhas. Mas também são os primeiros a colaborar com a dissimulação destas e na legitimação das avaliações extremamente positivas da alta administração quanto ao desempenho da empresa, mesmo que isso não seja na prática.

Por meio da leitura da revista, percebe-se o quanto a ABERJE tem seguido, de certa forma, as mudanças ocorridas nas relações produtivas, procurando fazer do leitor um conhecedor de fatores do cenário sócio-político, econômico e cultural que tem influenciado modificações na forma de gestão das organizações. Globalização, expansão de novas tecnologias da comunicação, intensificação da terceirização, por exemplo, são assuntos recorrentes nas matérias, reportagens, artigos e entrevistas diretamente relacionados às discussões da comunicação interna. Todavia, nota-se que estas reflexões representam o olhar e a compreensão que os empresários e gestores organizacionais têm sobre a realidade brasileira 
e, sobretudo, a respeito do mundo do trabalho e sua interface com a comunicação nas organizações. Entendimento, este, compatível com o pensamento dos próprios associados da ABERJE, desejosos, acima de tudo, por eficiência e eficácia nos seus negócios.

É importante notar que a revista evita colocar em pauta discussões que permitam a reflexão sobre os embates entre empregados e empregadores. Ao contrário, busca-se suscitar a idéia de que é possível a harmonização de interesses entre ambas as partes por meio da comunicação. Diálogo e maior proximidade entre gerentes e subordinados é um aspecto bastante presente nas falas dos que produzem a revista. Ao trabalhador é ofertada a possibilidade de emitir sugestões e opiniões sobre assuntos que envolvem a organização, especialmente quanto ao que afeta o seu trabalho. Isso é facilmente compreensível se consideramos a busca pelo controle organizacional por parte dos níveis gerenciais. $\mathrm{O}$ empregado é incentivado a compartilhar com suas chefias informações sobre seu cotidiano no ambiente de trabalho e sobre os fatores que podem ser mais bem dimensionados para o bom funcionamento da organização. Um dos lemas empresariais, incorporado pelo discurso da comunicação interna, intitulado de "transparência", representa muito bem isso.

Por mais que diversos estudiosos de comunicação interna ressaltem a necessidade de mais diálogo entre trabalhadores e empresas como um fator benéfico ao cotidiano dos primeiros no ambiente organizacional, é possível questionarmos se isto não seria, na verdade, uma estratégia da organização em combater os possíveis problemas que podem afetar o seu bom funcionamento administrativo e operacional. A "transparência" nas relações entre organizações e trabalhadores, deste modo, caberia muito mais para estes últimos que são incentivados a falar com franqueza às chefias e lideranças, emitindo opiniões e sugestões para a melhoria dos procedimentos organizacionais. Já as organizações, dada sua natureza, por outro lado, poderiam não necessariamente se interessar por uma rodada de discussões que realmente interessem ao trabalhador no seu dia-a-dia na organização.

Os responsáveis pela gestão da empresa não querem que os funcionários criem artifícios particulares para burlar o controle e as regras. Sob o ponto de vista da organização, não há interesse que os empregados criem suas próprias possibilidades de lidar com o trabalho, já que, com a interferência do empregado, o trabalho prescrito pode tornar-se diferente do trabalho real. As empresas querem evitar a intervenção do trabalhador na forma de ordenação do trabalho pensada pela alta administração e gerência como aquela que será mais eficaz e eficiente: 
"Na verdade, o que os gerentes modernos buscam para dirigir suas empresas é a transparência (...) Transparência, visibilidade tornam-se obsessões. As condutas, as práticas, os conhecimentos profissionais, as conseqüências mobilizadas, o engajamento das ferramentas devem ser acessíveis à compreensão dos que têm o poder de decisão." (LINHART, 2007, p.107).

Com mudanças profundas no mundo corporativo, particularmente devido à reestruturação produtiva com a assimilação de novas formas de gestão - exemplo do toyotismo -, as organizações articularam vários modos de assegurar o seu controle e a comunicação é um destes. Em concordância com esta intenção, a figura do "líder" como multiplicador dos objetivos organizacionais, bem como aquele que abastece a direção com informações sobre as práticas no ambiente de trabalho, começa a ser um dos assuntos recorrentes no periódico analisado nos anos de 2000. Ao líder cabe determinar, orientar, disseminar procedimentos de trabalho aos demais funcionários e dele também se exige participação ativa nas estratégias comunicacionais a favor prioritariamente dos interesses da empresa. O líder acaba sendo o vigilante do comportamento dos colegas de trabalho e portavoz do discurso institucional:

"A abertura de canais de duas mãos entre líderes e subordinados, seja via escrita ou oral, é vital para conscientizar e engajar funcionários numa mesma diretriz empresarial. A participação dos funcionários como verdadeiros embaixadores das empresas em relação aos diversos públicos, tem feito cada vez mais, com que as empresas incentivem a contribuição deles em atividade de comunicação. Seja em sugestões de pauta para os veículos internos, em conselhos editoriais ou em pesquisas e enquetes, promover o 'sentimento' de 'pertencer' enriquece os processos da organização como um todo." (Nada substitui o diálogo, n.45, 2002).

Com base nas orientações do toyotismo, as lideranças são consideradas um elo entre chefias e subordinados. Aquele que é entendido como "líder" tem a função de estimular o engajamento dos funcionários, procurando motivá-los a trabalhar conforme as diretrizes da empresa:

“(...) as lideranças aprendem a arte da manipulação como se fosse um procedimento científico. A empresa captura a subjetividade, manipula-a por 
meio de técnicas e se apropria dos resultados produzidos. Além disto, faz com que este procedimento se apresente como se fosse um cuidado com as necessidades básicas do trabalhador. Não basta pôr um colega para vigiar o trabalho do outro, é preciso fazer isso como se fosse uma forma de proteção." (LIMA, 2006, p.134).

O discurso da comunicação interna faz questão de exaltar a formação de redes de liderança formais ou informais como algo necessário ao êxito organizacional (MARCHIORI, 2006b). Assim, o líder na organização é compreendido como um formador de opinião com capacidade de convencer os demais trabalhadores a apoiar as decisões da alta administração, bem como a aceitar as diretrizes organizacionais.

Os textos da revista Comunicação Empresarial revelam uma relação entre comunicação e liderança atribuída pelos gestores organizacionais. Espera-se do líder que saiba transmitir as informações necessárias e de forma adequada aos times de funcionários. Consideram-se a comunicação e a liderança como fatores de mesma ordem:

"Liderança e comunicação são os elementos sempre presentes quando fazemos uma avaliação do ambiente de trabalho nos mais diversos tipos de organização. Quando a empresa é boa, há boa comunicação e boa liderança. Quando a empresa é excelente, excelentes são a comunicação e a liderança. E se a empresa ainda tem o que melhorar, em geral, é a comunicação o ponto fraco, assim como a qualidade da liderança. Sabemos que comunicação e liderança não são aspectos independentes na gestão das organizações. $\mathrm{Na}$ verdade, a boa comunicação é parte do correto exercício da liderança." (Empresa excelente, comunicadores líderes, n.59, 2006).

"Promover o sentimento de pertencer" tem sido uma das idéias mais presentes nas edições da revista da década de 2000 - precisamente de 2000 a 2007, período analisado aqui. A tentativa de envolver o trabalhador na cultura da organização, persuadindo-o a tomar para si valores que são próprios da empresa em que é empregado, aparece na revista como parte do discurso da comunicação interna. As estratégias de comunicação nas organizações ajudam a disseminar a missão da organização - sua razão de ser -, bem como a sua visão de futuro como deseja ser enxergada pela sociedade - ao “público interno”. Não importa o cargo ou a função do empregado, interessa à empresa que ele esteja o máximo possível de acordo com os seus ideais. Não podemos esquecer, entretanto, que, se mesmo por um lado o trabalhador assujeita-se às determinações da empresa, enfrentando constrangimentos e sofrimento, por 
outro lado, a sua adesão à configuração das formas de gestão produtiva da organização apresenta-se como uma adesão circunstancial, sem representar em essência a de livre e espontânea vontade.

Todas as estratégias de incorporação do trabalhador à racionalidade da organização, discutidas até aqui, demonstram que o discurso da revista Comunicação Empresarial está em compasso com a literatura de comunicação interna, bem como com a ótica empresarial. Os demais aspectos escolhidos para orientar a análise da revista, discutidos nas próximas páginas, nos revelarão se esta percepção, em relação ao que é produzido pela associação, poderá ser mantida ou não.

\section{Acessibilidade à informação}

As organizações apresentam grande preocupação com a circulação de informações no ambiente de trabalho, sendo este mais um aspecto significativo tratado no periódico da ABERJE. Possibilitar ao funcionário conhecer sobre assuntos relacionados à organização é um propósito muito claro no discurso emitido pela publicação. Existe a intenção clara de manter o trabalhador informado sobre fatores que podem colaborar para seu melhor desempenho no ambiente de trabalho, sempre, evidentemente, em concordância com os preceitos organizacionais ali estipulados.

Os gestores das empresas destacam a fluidez de informações no âmbito organizacional como algo primordial nas relações com os trabalhadores. Neste contexto, os instrumentos de comunicação recebem grande atenção, sendo que os mais citados no periódico analisado são: revistas, jornais, boletins, eventos, videojornais, rádio empresa, quadro de avisos, murais, teatro empresa e intranet. Encontro com o presidente da empresa para tomar café da manhã, por exemplo, é vinculado às matérias da revista como um dos principais instrumentos para que os empregados possam compartilhar suas idéias com a alta administração da empresa, especialmente quando referidos no âmbito dos programas de qualidade total: 
"Um canal de excelente aceitação nesse tipo de programa são as reuniões participativas, onde funcionários de diversos setores tomam café da manhã com o presidente, ou com a cúpula da organização, para expor suas posições de modo franco e aberto." (Parceria indispensável, n.12, 1994).

Significativos investimentos financeiros são aplicados para que estes instrumentos de comunicação sejam produzidos de forma que transmitam as informações previamente selecionadas pelos gestores organizacionais. Apesar do discurso da "transparência” divulgado incessantemente pelas organizações, percebemos que esta máxima parece valer, na verdade, principalmente para o comportamento dos funcionários, pois as próprias fontes da revista Comunicação Empresarial anunciam a posição das organizações frente a esta questão:

"Você deve ter bem definidas que estratégias estarão disponíveis ou não. Algumas empresas tratam de explicar suas estratégias globais e outras têm medo. As informações competitivas precisam ser seguras e ficar restritas, são atitudes conservadoras do management e do mercado. Então, precisamos selecionar o que dizer a cada grupo e lidar com essas informações de forma transparente. É como uma regulamentação. Você tem muita informação global que pode dizer a todos e, ao mesmo, pode dosar o acesso às informações." (A pressão leva à transparência, n.40, 2001).

Sabemos que os conteúdos desenvolvidos nas mídias internas têm o caráter prioritário de apresentar notícias positivas sobre a organização. Isso não significa que as notícias de cunho negativo não possam fazer parte destes materiais. Observamos, por exemplo, no periódico analisado a orientação também de informar os fatos negativos nas publicações internas, mesmo aqueles que podem causar grandes questionamentos devem ser informados aos funcionários. Tal medida, sob a ótica dos enunciadores da revista, contribui para uma menor polêmica sobre assuntos que, de uma forma ou de outra, já seriam foco de discussão entre os funcionários. Acidentes de trabalho, greves e reivindicações salariais são exemplos dos temas que podem causar debates entre trabalhadores e embates com a própria organização. Dessa forma, os gestores das empresas começaram a perceber a vantagem de sempre mostrar seu ponto de vista aos trabalhadores:

"A greve, que durante muito tempo fez parte do index prohibitorium das publicações internas (enquanto os jornais dos sindicatos deitavam e rolavam) é cada vez mais vista como informação a ser divulgada, analisada e 
discutida, com a empresa utilizando o jornal (ou revista) para deixar clara sua posição." (Adeus à política do avestruz, n.2, 1991).

Se por um lado o discurso da revista e da própria comunicação interna deseja que esta atitude seja compreendida como uma amostra de consideração da empresas pelos interesses de seus funcionários, por outro lado, podemos questionar se a organização não estaria agindo dessa forma para anunciar quais são as posturas aceitas no ambiente de trabalho com o intuito que os trabalhadores se adaptem a elas. Pode-se pensar que a intenção da empresa em pautar este tipo de assunto, como a greve, em suas publicações, é que os funcionários já saibam de antemão quais são as suas opiniões sobre os acontecimentos, servindo até mesmo de parâmetro para suas conversas com outros funcionários e em reuniões com seus superiores. Os materiais de comunicação interna são lidos pelos empregados porque é uma fonte oficial de conhecimento do discurso da empresa, mostrando qual é a cultura da empresa, isto é, "tais documentos indicam as linhas mestras do conformismo em relação à evolução do espírito da casa." (DEJOURS, 2007, p.71). Até mesmo porque o trabalhador dificilmente se arriscará em contrariar a opinião da empresa no ambiente de trabalho com vistas a sofrer algum tipo de repreensão.

Nota-se a sobreposição do discurso da empresa aos questionamentos e interesses dos trabalhadores. Aliás, as organizações se preocupam fortemente com os boatos e as conversas dos funcionários que fogem de seu domínio e a revista alerta que "é importante as empresas retomarem o controle das informações no ambiente interno, serem donas das informações que elas próprias geram” (Contra rumores, dois remédios, n.2, 1991), bem como que “a Rádio Peão é o principal inimigo da informação” (Idem).

Coerentemente com este tipo de orientação, os estudos de comunicação interna destacam a atenção que os gestores organizacionais devem ter com o que se denomina "comunicação informal", ou seja, com o tipo de enunciado que não é emitido pelo discurso oficial da empresa ("comunicação formal”), mas, sim, construído pelos funcionários com base em seus pontos de vista sobre as situações ou os assuntos discutidos no ambiente de trabalho. Entende-se que a "comunicação informal" pode deslegitimar as mensagens emitidas pela organização e desestabilizar a sua ordem interna.

É perceptível que o processo comunicativo, neste contexto, é entendido sob o foco principal da transferência de mensagens. A organização preocupa-se com fatores que podem 
interferir no envio de informações aos funcionários. A "Rádio Peão", por exemplo, é considerada como um ruído ou um empecilho ao êxito da comunicação planejada por seus gestores. Isto não significa que a organização queira proibir ou impossibilitar que os funcionários participem do processo comunicativo no ambiente de trabalho como interlocutores ativos. Pelo contrário, observa-se que há certo incentivo aos funcionários transmitirem e compartilharem informações com os demais funcionários e áreas da empresa:

"O primeiro passo para a obtenção da qualidade total é a aproximação das pessoas, que devem dispor de canais para veicular suas opiniões e sugestões, não importando o nível hierárquico em que estejam. É primordial, nesse sentido, a eliminação da burocracia e de quaisquer empecilhos ao bom fluxo da comunicação interna. Se, através, de ações desalinhadas, a fluidez da informação for truncada, não alcançando da mesma maneira todos os patamares funcionais, nenhum projeto de qualidade decolará, mesmo embasado em planos e estratégias traçados no âmbito de uma diretoria bem intencionada." (Parceria indispensável, n. 12, 1994).

O discurso do periódico analisado, bem como da comunicação interna, busca convencer o leitor que este incentivo à disseminação de informações é uma prova de que as organizações aceitam a possibilidade do trabalhador ser o sujeito ou o "ator social" do processo de comunicação no ambiente de trabalho. Entretanto, sabemos que isso é condição fundamental para o alcance da eficácia e da eficiência das formas de gestão e dos processos produtivos da empresa - como, por exemplo, aqueles baseados nos programas de qualidade total-, visto que seu êxito depende do maior acesso dos empregados às informações que facilitem a operacionalização de seu trabalho.

Sob este prisma, a utilização de instrumentos de comunicação internos à organização é intensificada, sendo significativa a atenção voltada às novas tecnologias que possam tornar possível a disseminação rápida de informação aos funcionários. Grande importância começa a ser dada às mídias digitais nos processos comunicacionais internos às organizações, especialmente nas edições do final da década de 1990 da revista e ganhando um espaço significativo nos anos 2000. Exemplo disso é a matéria de capa da edição de n.30, de 1999, que trata da necessidade de adequar a linguagem administrativa para transmitir informações aos funcionários. Com a utilização de e-mail e intranet, as empresas começam a perceber as vantagens do uso da rede informatizada de comunicação: 
"Para a empresa, a intranet agrega agilidade, segurança, cria sinergia, tem custo menor, aumenta produtividade, modela interação, permite comunicação mais espontânea, influencia interação, tem efeito democratizador e as informações em rede são mais flexíveis e dinâmicas." (Força intrínseca, n.37, 2000).

Observa-se que o periódico analisado enaltece a utilização da intranet como um instrumento que surge para possibilitar uma maior dinamicidade ao processo comunicativo, $\mathrm{o}$ qual é entendido prioritariamente como transmissão de informação. Neste sentido, compreende-se que os instrumentos de comunicação, como é o caso da intranet, são um dos principais fatores que podem promover o bom funcionamento da organização, vistos como essenciais na disseminação das diretrizes e valores organizacionais aos trabalhadores no ambiente de trabalho.

Não obstante o advento das mídias digitais, o trabalhador continua sendo considerado um receptor passivo no processo comunicativo interno às organizações. Nota-se uma simplificação e objetividade extrema na transmissão de informações com a justificativa que os funcionários não têm tempo para ler ou acessar os materiais produzidos ou que não conseguem compreender as mensagens emitidas. Deste modo, "as práticas discursivas vão sendo progressivamente uniformizadas por baixo, com vistas ao discurso padronizado, sempre apelando para os slogans, os estereótipos, as fórmulas prontas, que desgastam o conteúdo semântico.” (DEJOURS, 2007, p.68).

Os instrumentos de comunicação são destacados fortemente pela retórica da revista Comunicação Empresarial como estratégicos porque estes se tornaram os grandes mediadores da discussão entre organizações e trabalhadores no ambiente de trabalho, sendo o discurso oficial da organização - respaldado pela comunicação interna - o norteador deste debate. 


\section{Individualização do trabalhador}

Particularizar as relações com o trabalhador tem sido uma das estratégias utilizadas pelas organizações com o fito de engajá-lo ainda mais no processo produtivo. O empregado é tratado cada vez mais de forma individualizada especialmente para sentir-se um grande responsável pelo desenvolvimento da empresa e, consequentemente, esforçar-se o máximo possível para o sucesso desta no cenário competitivo em que se encontra.

A tentativa de individualização do trabalhador faz parte do projeto de modernização das relações de trabalho, buscando, dentre seus outros propósitos, desarticular qualquer tipo de manifestação coletiva de trabalhadores contrária aos interesses organizacionais (LINHART, 2007). A exaltação das qualidades individuais dos trabalhadores começa a aparecer nos discursos das empresas com mais intensidade ao se destacar a competência, o talento, as premiações individuais, a importância da profissionalização, a valorização da carreira, o esforço individual e, acima de tudo, a responsabilidade individual pelo trabalho e por sua melhoria.

Percebe-se que esta maneira de tratar o trabalhador mostra-se diferente daquela observada no taylorismo. Nesta nova configuração, destacam-se o reconhecimento do saber dos trabalhadores - independentemente de suas qualificações ou funções - e a valorização de suas experiências por parte das organizações, as quais aceitam agir dessa forma em troca da boa vontade e do apoio dos empregados.

$\mathrm{Na}$ leitura crítica do periódico, identificamos alguns indicativos que demonstram o discurso da individualização do trabalhador. Determinadas experiências de empresas relatadas na revista explicitam a busca da conformidade do comportamento do empregado às necessidades organizacionais, conferindo atenção à responsabilidade individual do funcionário no desenvolvimento da empresa ao dedicar-se com afinco à realização de seu trabalho:

"Ao longo dos anos, incorporou-se à cultura da Copesul a disposição de todas as pessoas nela empregada se dedicarem a fazer bem feito seu trabalho, ou qualquer outra atividade relativa à vida na empresa. Da telefonista ao vigilante da portaria, que são os primeiros contatos de quem se dirige à Copesul, até à pessoa da mais alta responsabilidade dentro da organização, todos estão convencidos de que sua tarefa é de fato importante para o 
resultado final e se esforçam para executar o melhor possível suas atribuições." (Receita de excelência, n.26, 1998).

Nota-se que, independente de sua posição na hierarquia da empresa, cada trabalhador é incentivado a preocupar-se em desempenhar as suas tarefas em colaboração ao êxito organizacional. A responsabilidade pela eficiência da empresa não cabe mais principalmente ao desempenho da gerência; aos empregados, de forma geral, é dada tal responsabilidade, até mesmo porque, a rígida hierarquização começa a ser combatida em prol da efetividade das demandas organizacionais, como é possível constatarmos na fala do executivo de uma grande empresa em entrevista à revista:

"Os níveis hierárquicos baixaram de sete para três - só temos agora direção, facilitadores e colaboradores. $\mathrm{O}$ antigo funcionário especialista deu lugar ao colaborador com polivalência e multiabilidades, com capacidade para suprir prontamente uma necessidade emergencial. (...) Em toda a empresa, as chefias foram substituídas por lideranças de grupos. Todo corpo funcional foi organizado em grupos de trabalho - os times - liderados por um facilitador que, como o próprio nome indica, é um colaborador que facilita a ação do time em suas tarefas, no relacionamento com os outros times e com o nível hierárquico superior." (Receita de excelência, n.26, 1998).

Observa-se que as empresas buscam reduzir os níveis hierárquicos, resultando numa maior responsabilização dos funcionários por seu trabalho, tratados como coresponsáveis pelos procedimentos gerais implantados na organização. São incentivados a tomar decisões de forma autônoma, agilizando os procedimentos organizacionais e a comunicação é tida neste contexto como instrumento de persuasão dos funcionários a agir da maneira desejada pela empresa:

"Uma pessoa que está apertando um parafuso na linha de montagem não deve saber apenas qual é a sua responsabilidade ao apertar o parafuso. Deve saber que ela é parte de um processo por meio do qual um determinado produto chegará ao lar de alguém, que irá utilizá-lo e deverá ter plena satisfação com seu funcionamento, qualidade, estética etc. Outra parte de grande importância é a ética do comportamento. Uma empresa séria tem de ter um funcionário sério, seja frente à sua comunidade ou perante a sociedade como um todo. Ora, para envolver milhares de funcionários nessa 
campanha, e não apenas a cúpula, a comunicação é fundamental." ("Sem comunicação, uma empresa não existe", n.18, 1996).

Difunde-se a idéia de que o trabalhador não deve depender de uma chefia imediata para ordenar cada tarefa a ser realizada, mas, sim, precisa sentir-se como uma pessoa com determinação e firmeza para tomar decisões próprias, responsabilizando-se, inclusive, por todos os riscos que disso possam existir. A flexibilização das estruturas hierárquicas contribui para o maior acesso às informações e para certa descentralização da tomada de decisão, reforçando a idéia que o trabalhador tem autonomia na realização de seu trabalho. Por outro lado, estas situações de individualização do trabalho levam o empregado a assumir mais responsabilidades sem o verdadeiro poder de tomar qualquer decisão sozinho.

Apesar da solicitação de maior envolvimento com as questões da empresa, sendo responsabilizados pelas demandas de qualidade, eficácia e eficiência na realização de seu trabalho, o empregado, na prática, raramente recebe autonomia suficiente para cumprir com seus deveres. Isso acaba gerando certo descontentamento e angústias no ambiente de trabalho, os quais são minimizados pelos "líderes organizacionais". Estes, já destacados anteriormente como personagens importantes para o sucesso da tentativa de incorporação do trabalhador à racionalidade da empresa, acabam fazendo o papel de incentivadores no ambiente de trabalho ao motivar os demais empregados a incorporarem a atitude de responsabilização por suas ações em prol do desenvolvimento da empresa. Representados por funcionários, em grande parte originados do corpo gerencial, os líderes são considerados importantes disseminadores das mensagens organizacionais no ambiente de trabalho e deles a empresa espera total comprometimento com os objetivos de convencer os demais funcionários a compartilhar os mesmos interesses da organização.

A questão da tentativa de personalização das relações da organização com o trabalhador é acompanhada de um outro aspecto também bastante observado na retórica da revista, ao tratar de assuntos ligados à comunicação interna: a valorização do funcionário como ser humano. É um traço marcante das estratégias de comunicação pensadas com o propósito de mobilização da subjetividade do trabalhador que merece ser discutido nas próximas páginas. 


\section{Valorização do trabalhador como pessoa}

O discurso da valorização do trabalhador como ser humano é representado pela revista Comunicação Empresarial por meio de diversos elementos discutidos nas matérias, reportagens e artigos analisados, dentre os quais identificamos como os mais significantes: qualidade de vida do empregado, a vida do trabalhador fora do ambiente de trabalho, aproximação da empresa à família do funcionário, alusão ao trabalhador como cidadão. Todos estes elementos, de uma forma ou de outra, são considerados elementos que compõem as estratégias de comunicação interna na tentativa de mobilização da subjetividade do trabalhador.

Nota-se grande interesse do periódico em mostrar ao leitor as ações realizadas pelas organizações supostamente preocupadas com o bem-estar do trabalhador. Os chamados programas de valorização da qualidade de vida dos trabalhadores nas empresas são exemplificados por meio de oferecimento de benefícios sociais como assistência médica e odontológica. Também, são promovidas campanhas de conscientização que abarcam os temas saúde, educação, dentre outros. Estas idéias são desenvolvidas, geralmente, pela área conhecida como "Recursos Humanos" ou "RH" das empresas e estratégias de comunicação são utilizadas com a finalidade de apoiar a implantação das ações planejadas:

“(...) com apoio da equipe de comunicação corporativa, o serviço médico da empresa deu início à primeira etapa de um programa antitabagista que coincidiu com o Dia Mundial do Combate ao Fumo. A proposta inicial foi buscar a conscientização dos funcionários. Por meio de folhetos e também de uma edição especial da revista interna O Viking, todos empregados da Volvo tiveram acesso a informações detalhadas sobre as conseqüências da nicotina para a saúde. Outra estratégia utilizada para despertar o interesse dos empregados foi a venda de camisetas com o símbolo da campanha. A campanha visava vender 500 camisetas, mas logo atingiu a mil unidades ao final de uma jornada de trabalho." (Cortina de fumaça, n.21, 1996).

Não raramente as empresas buscam aliar sua imagem a campanhas de interesse público para tentar atrair a simpatia da sociedade, utilizando-se disso, também, para cumprir determinadas leis, como é o caso do tipo de campanha destaca no trecho anterior, visto que na 
época em que esta matéria foi publicada havia sido proibido o fumo em recintos fechados. Aproveita-se, além disso, para envolver os funcionários nestas atividades com a justificativa de que estas são positivas para a suas vidas e que as empresas estão cuidando de seu bem-estar no ambiente de trabalho, sendo que a expectativa da organização é de retribuição por tamanho zelo em forma de mais comprometimento e esforço do trabalhador.

As famílias dos funcionários também começam a ser alvos destes programas de qualidade de vida. Sob o ponto de vista dos gestores, é de grande importância para as empresas que os familiares apóiem a vida do trabalhador no seu ambiente de trabalho. Pois, com a aprovação da família quanto ao seu trabalho e à organização que o emprega, o funcionário supostamente sente-se mais motivado a engajar-se nos propósitos da empresa. Deste modo, os programas de visita das famílias às organizações são incentivados:

"Em busca de maior integração possível com a comunidade, em junho de 1993 a Volvo criou o subprograma 'seja bem-vindo', que promove visitas de esposas, filhos e familiares de funcionários à fábrica, sempre entre os dias 05 de julho e 13 de agosto. No caso dos solteiros, os pais são convidados. Os grupos de visitantes participam de palestras diárias sobre benefícios sociais da empresa e sua correta utilização. A ação estendeu-se também à orientação familiar, discussão de problemas habitacionais e divulgação de noções de economia, educação e saúde. Há espaço ainda para palestras sobre relacionamentos interpessoais e orientação em casos de dependência do álcool e outras drogas.” (O gigante está acordado, n.14, 1995).

Estes programas de visitas, também conhecidos como programas de "portas abertas", são destacados freqüentemente na revista, não só na década de 1990, como também nos anos 2000, como um tipo de estratégia que incentiva maior participação do funcionário na vida da empresa.

É possível observar que, até mesmo, outros meios foram criados com o intento de se conseguir a boa vontade e o suporte das famílias do empregados. Vários canais de comunicação são utilizados como jornais e outros tipos de materiais enviados diretamente para a residência dos empregados com informações sobre benefícios sociais oferecidos pela empresa entre outros assuntos que ressaltem a suposta preocupação da organização com o bem-estar de seu funcionário e de sua família. 
Ainda com o objetivo de envolver cada vez mais o trabalhador, as organizações buscam interferir na sua vida fora do seu ambiente de trabalho, ou seja, na sua vida privada. Ações direcionadas à vida de seus familiares são exemplos disso:

"Com quatro anos de existência, o projeto mostra aos filhos dos 470 funcionários como uma indústria química pode conviver em harmonia com o meio ambiente. Utilizando jogos, cartilhas, gibis e outras ferramentas, as crianças de 6 a 9 anos aprendem noções de ecologia e como a atividade de seus pais na empresa protege o meio ambiente. Desta forma, o funcionário se vê na necessidade de explicar seu trabalho e pensar sobre como ele contribui para este Programa. Já com as crianças de 11 a 13 anos, há álbuns de figurinhas que retratam a região e as instalações para controle ambiental feitas pela Solvay, no local onde está localizada sua fábrica de Paranapiacaba, em Santo André (SP). Do mesmo modo, a criança precisa pedir indicações ao pai para saber onde colar as figurinhas, fazendo-o participar automaticamente do desenvolvimento do trabalho de treinamento de pessoal.

A faixa etária dos 15 aos 18 anos é atingida com uma espécie de vestibulinho em que os adolescentes recebem um fichário escolar com divisórias contendo informações a respeito de ecologia e controle ambiental. Aqueles que acertarem o maior número de pontos ganham prêmios que variam de bicicletas a games e microcomputadores." (Conhece-te a ti mesmo, n.36, 2000).

Claramente percebe-se a tentativa da empresa em difundir seus valores na vida privada do trabalhador ao planejar estratégias e instrumentos que possam alcançar a sua relação familiar. O laço emotivo com os filhos torna-se alvo da organização para conseguir uma aproximação maior com o trabalhador.

Verifica-se, também, por meio da leitura crítica que fizemos da revista, o discurso que exalta o trabalhador como cidadão, tratando-o como um ser humano que tem várias qualidades e talentos que extrapolam o seu papel de empregado:

"Atividades significativas também são os Clubes de Sinergia, formados espontaneamente por colaboradores de todas as regiões do País. Temos 12 clubes que se reúnem regularmente, discutem a sua atividade, propõem novos processos e soluções de trabalho. É uma participação enriquecedora para eles e para a Accor Brasil, que já adotou muitas das suas idéias. Temos também o Programa Qualidade de Vida, que se preocupa em despertar os colaboradores para um modo de vida mais saudável. Temos ainda a Oficina 
de Talentos, igualmente criada por iniciativa dos colaboradores, que reúne nossos talentos nas áreas de artes, dos esportes e das atividades de responsabilidade social. Foi da Oficina de Talentos que surgiu o Coral Accor Maior, por exemplo. A Academia, por sua vez, é o maior propulsor da nossa comunicação interna e por ela já passaram mais de 13,3 mil colaboradores da Accor Brasil. Ela responde não só pelo treinamento e aperfeiçoamento profissional dos nossos colaboradores, mas também pela difusão de nossa filosofia empresarial." (Comunicar para servir bem, n.37, 2000).

O trecho anterior demonstra que os funcionários, mesmo em situações que não envolvem diretamente a realização de seu trabalho, são alvos da tentativa de imposição da moral da empresa. As organizações só consentem e promovem estes tipos de atividade porque sabem que, dentro do processo de gestão comunicativa, podem utilizá-las para disseminar ainda mais os seus valores aos empregados. O discurso da fonte deste trecho da revista imprime a idéia de que os trabalhadores são os verdadeiros idealizadores das atividades que compõem o "Programa de Qualidade de Vida" referido. Sabemos que, na prática, isso não ocorre dessa forma, pois a empresa só permitirá aquilo que for compatível com seus valores e interesses. Mas no momento em que ela afirma que tais atividades são uma escolha dos próprios funcionários, naturaliza este tipo de ação, escondendo as suas reais intenções e conferindo uma suposta participação do trabalhador nas decisões da empresa.

Ainda neste contexto, poderíamos dizer que as organizações querem participar da vida do trabalhador em todos os momentos possíveis, utilizando de estratégias de comunicação para alcançar este fim. Trazer a vida privada do trabalhador para dentro do ambiente de trabalho, relacionando-a aos próprios valores organizacionais, é, neste contexto, um artifício realizado com o apoio da comunicação interna:

"As demais edições visam apreender os temas relacionais em desenvolvimento; as famílias que trabalham na empresa; as histórias de amor originadas na empresa (namoros, casamentos); histórias de grandes amizades construídas no trabalho; o desafio de ser homem numa organização feminina. Com o sucesso do veículo, pautas surgidas no coletivo da empresa têm sido incorporadas ao jornal. Um exemplo dessas pautas é a reportagem central da edição de número seis, que tratou das diferentes atividades esportivas, praticadas por funcionários da Daslu, da corrida à ioga, da capoeira à natação. 
O jornal é entregue às funcionárias e funcionários da Daslu de maneira personalizada. Cada pessoa recebe o Daslu Notícia com uma etiqueta em seu nome." (Como entender a alma da organização, n.55, 2005).

Ao valorizar a vida privada do trabalhador no ambiente de trabalho, tornando conhecidas as atividades que lhe dão algum prazer nas suas relações pessoais entre seus colegas de trabalho, a organização está procurando demonstrar ao empregado que ela o considera como um indivíduo que desempenha outros papéis além de funcionário da empresa. Esperase, assim, que este se sinta reconhecido como um ser humano, como pessoa, como cidadão e esteja convencido que a organização apóia seu comportamento, o qual acaba, até mesmo, tornando-se o modelo de comportamento aprovado pela empresa aos demais funcionários.

A valorização do trabalhador como pessoa é dos aspectos mais bem utilizados pelas organizações na tentativa de mobilização da subjetividade dos funcionários a ponto destes, algumas vezes, confundirem seus próprios valores com os valores da empresa em que trabalham.

As análises desenvolvidas neste capítulo trouxeram algumas pistas de como a ABERJE, por meio de sua principal publicação - a revista Comunicação Empresarial compreende as relações entre trabalhadores e organizações. Os aspectos "incorporação do trabalhador à racionalidade da empresa", "acessibilidade à informação", "individualização do trabalhador" e "valorização do trabalho como pessoa" serviram de guias para que desenvolvêssemos um olhar mais crítico em relação à retórica da revista e da própria comunicação interna. Neste momento, após a realização destas análises, poderíamos até mesmo afirmar que os estudos de comunicação organizacional por nós aqui estudados coincidem com o discurso da ABERJE quanto ao entendimento das relações entre trabalhadores e organizações. Os aspectos tratados pelas vozes autorais da corrente de pensamento da comunicação organizacional - estudada nos capítulos I e II desta dissertação concordam, em certa medida, com os aspectos analisados na revista publicada pela associação. 


\section{Considerações Finais}

Ao longo de nosso percurso acadêmico e de nossa constante busca por um entendimento mais aprofundado e crítico sobre a área de conhecimento da comunicação organizacional, deparamos com um assunto que tem nos despertado grande interesse de estudo: as relações entre trabalhadores e organizações.

Com base na literatura nacional disponível de estudiosos significativos da área, observamos que o fator trabalho pouco tem sido discutido nos estudos de "comunicação interna" e do próprio campo mais abrangente da comunicação organizacional. Esta constatação prévia, a partir de uma investigação preliminar da área, nos instigou a entender mais de perto as razões deste desinteresse. Mais do que isso, nos colocou à frente do seguinte questionamento: "é possível refletir sobre a comunicação organizacional sem compreender com mais clareza as configurações e transformações contemporâneas no mundo do trabalho?”.

Esta questão nos levou, em paralelo à busca de conhecer com mais profundidade os aspectos estruturais da área da comunicação organizacional, a ampliar nosso entendimento sobre o fator trabalho nas relações sociais contemporâneas. Para tanto, as leituras de obras do campo da sociologia do trabalho mostraram-se reveladoras. Estas nos auxiliaram a entender melhor o mundo do trabalho e as modificações pelas quais tem passado ao longo de suas condições históricas. Modificações, estas, aliás, que não deslegitimam o trabalho como categoria central e norteadora das relações sociais na contemporaneidade.

Apesar de alguns estudiosos da sociologia do trabalho, como Gorz (1982) e Offe (1984), questionarem este caráter de centralidade do fator trabalho, Antunes (1999; 2005) oferece argumentos bastante plausíveis e sólidos para compreendermos o contrário. Isto é, para considerarmos o trabalho como o principal mediador das relações sociais. Não o único, mas o mais significativo.

Antunes $(1999 ; 2005)$ traz à tona que muitas têm sido as mudanças no mundo do trabalho, especialmente devido às formas flexíveis de acúmulo do capital. Exemplos disso são: o crescimento do trabalho terceirizado e a redução do proletariado fabril. Sob este contexto das mudanças no mundo do trabalho, o que mais nos chamou a atenção, no entanto, foram os aspectos formadores das tentativas das organizações em mobilizar a subjetividade do 
trabalhador. Aspectos compreendidos como resultantes das formas de reestruturação produtiva do capital, dentre as quais o toyotismo ganha destaque.

O toyotismo, considerado como uma escola japonesa de gestão da produção, busca a intensificação do trabalho nas organizações por meio, dentre outras atitudes, da despecialização dos trabalhadores, transformando-os em funcionários polivalentes, e da linearização da produção (CORIAT, 1994). Neste cenário, aumenta a responsabilização do empregado pelo processo de trabalho, sendo cada vez mais exigido seu envolvimento na vida da organização. Os aspectos que influenciam a subjetividade do trabalhador e, consequentemente, o processo do trabalho, portanto, despertam fortemente o interesse das organizações. Tentativas de incorporação do trabalhador à racionalidade da organização e de individualização do trabalhador, incentivo à acessibilidade à informação e valorização do trabalhador como pessoa são algumas das estratégias que acabam sendo utilizadas pelas organizações, de uma forma ou de outra, para mobilizar a subjetividade do funcionário, conforme os diversos autores estudados do campo da sociologia do trabalho.

Este percurso de investigações preliminares sobre as mudanças no mundo do trabalho na contemporaneidade e a respeito do campo da comunicação organizacional foi fundamental para formularmos o objetivo principal desta dissertação de mestrado: analisar criticamente a ótica que significativas vozes autorais e a voz institucional da ABERJE, dentro da área da comunicação organizacional, têm sobre as relações entre trabalhadores e organizações.

A ABERJE entra neste contexto porque, como foi possível entender ao longo do desenvolvimento desta dissertação, tem se apresentado como forte influente na formação do campo de conhecimento e, até mesmo científico, da comunicação organizacional no Brasil.

Conforme este horizonte, procuramos analisar criticamente certas vozes autorais da área por meio de suas produções científicas. A escolha de obras e autores não foi aleatória e assistemática. Já que estávamos falando de um certo pensamento hegemônico, buscamos escolher obras de destaque e já reconhecidas pela própria academia. Tomar estas obras como legítimas representantes de uma área de conhecimento está aliada à própria difusão que estas obras têm em nosso cenário de conhecimento. Obviamente, não quer dizer que não reconheçamos outros esforços dentro da área. Eles existem, mas ainda são timidamente reconhecidos se postos em face à difusão destes outros estudos. O que está em jogo aqui não é o que está se modificando ou experimentando, mas aquilo que se fixou fortemente como idéia central e difundida como "verdade" de uma área de conhecimento. 
E, além disso, e em complemento ao que foi exposto anteriormente, desenvolvemos uma análise crítica da voz institucional da ABERJE por meio de sua revista Comunicação Empresarial, sendo balizada por quatro eixos temáticos levantados a partir do conhecimento adquirido pelas leituras do campo da sociologia do trabalho, conforme já destacamos anteriormente: (I) incorporação do trabalhador à racionalidade da organização; (II) acessibilidade à informação; (III) individualização do trabalhador; (IV) valorização do trabalhador como pessoa.

Todo este caminho trilhado para o desenvolvimento desta dissertação foi fundamental para alcançarmos nosso objetivo principal e levantarmos possíveis interpretações a respeito da área da comunicação organizacional no Brasil e, ainda, despertar e sugerir novas perspectivas de futuros estudos.

A seguir destacaremos algumas das considerações possíveis de serem expostas como frutos de nossas investigações:

(I) Observa-se a opção preponderante das vozes estudadas de pensar a comunicação de/nas organizações sob os aspectos da gestão estratégica organizacional. Esta escolha imprime à área da comunicação organizacional um teor de planejamento, administração e controle do processo comunicativo a favor prioritariamente do bom funcionamento das organizações. Os traços recorrentes das idéias dos autores que, a nosso ver, representam o discurso hegemônico da área, demonstram este caráter de gestão estratégica impresso à forma de se pensar a comunicação. E a voz institucional da ABERJE também tem demonstrado este aspecto bem explicitado na enunciação de sua própria visão e sua missão.

(II) Sob a luz da gestão estratégica, a área da comunicação organizacional está principalmente preocupada em pensar estratégias comunicacionais que possam agregar valor aos negócios das empresas, propiciando resultados positivos para o seu êxito.

(III) A comunicação organizacional está em compasso com as necessidades das formas de gestão produtiva das organizações no que tange as tentativas de mobilização da subjetividade do trabalhador. Um dos momentos do desenvolvimento da dissertação que demarca muito bem esta constatação refere-se às análises da revista Comunicação Empresarial com base nos eixos temáticos, os quais foram pensados a partir dos estudos do campo da sociologia do trabalho. Nota-se que só foi possível analisar os textos da revista por meio destes eixos temáticos porque a área da comunicação organizacional segue as modificações no 
mundo do trabalho, mesmo que, em muitos momentos e em circunstâncias teóricas, não faça deste conhecimento uma possibilidade de reflexão interpretativa e crítica.

(IV) A compreensão que as vozes estudadas da área têm do processo comunicativo nas relações entre trabalhadores e organizações ainda é fundamentalmente pautada pela perspectiva funcionalista. Enquanto a comunicação for compreendida como ferramenta estratégica, seja com base nas mídias/instrumentos ou nos aspectos simbólicos como a cultura organizacional, as concepções comunicativas continuarão sendo construídas com base no paradigma funcionalista.

(V) As articulações do discurso da voz institucional da ABERJE aproximam-se fortemente da retórica das vozes autorais da comunicação organizacional e da "comunicação interna” estudadas. Esta constatação reforça a hipótese que esta associação tem sido forte influente na formação do campo brasileiro científico da comunicação organizacional.

(VI) As relações entre trabalhadores e organizações são compreendidas de maneiras diferentes pelos campos da sociologia do trabalho e da comunicação organizacional. De forma sintética, o primeiro apresenta uma visão crítica de como as relações de trabalho são modificadas por meio das estratégias de mobilização da subjetividade do trabalhador. Isto acaba explicitando as contradições existentes nestas relações, revelando aspectos de poder e dominação. Já o campo da comunicação organizacional, a partir do seu pensamento hegemônico, está mais preocupado em planejar estratégias de comunicação que possam auxiliar nas tentativas da organização em mobilizar a subjetividade do trabalhador, incorporando-o à própria racionalidade da organização.

(VII) O fator trabalho mostra-se fundamental não somente para os momentos decisivos da formação da área da comunicação organizacional no país, como também tem sido uma questão central na formulação de todo um campo brasileiro científico da comunicação organizacional. A sociologia do trabalho pode funcionar, neste sentido, como um diálogo interdisciplinar imprescindível à área da comunicação organizacional.

As considerações apontadas anteriormente, acima de qualquer coisa, nos mostram que ainda existem muitos outros caminhos investigativos a serem percorridos. Certamente, são novas vias, novos enfoques que podem levar a uma compreensão mais aprofundada, reflexiva e crítica a respeito da comunicação nas relações de trabalho no contexto da comunicação organizacional. 
Neste momento, longe de ser a última palavra sobre o assunto, nós somente percorremos um destes caminhos que certamente não consegue responder a todas as indagações que possam surgir quando o foco é a comunicação nas relações de trabalho. Por outro lado, entendemos que esta dissertação cumpriu seu papel de forma honesta e coerente: foi capaz de dar um passo a mais no debate acadêmico, ao levantar o problema de pesquisa sobre as concepções da comunicação organizacional quanto às relações entre trabalhadores e organizações. 


\section{Referências bibliográficas}

ABRAHAM, Cal. Processo de relações entre empregadores e empregados. Revista de Organização e Produtividade. São Paulo, v.25, n.297-298, p.52, 1956.

ADORNO, Theodor W.; HORKHEIMER, Max. A Indústria cultural: o esclarecimento como mistificação das massas. In: Dialética do Esclarecimento: fragmentos filosóficos. Tradução Guido Antonio de Almeida. Rio de Janeiro: Jorge Zahar Editor, 1985. p.113-156.

AGLIETTA, Michel. Las transformaciones del proceso de trabajo. In: Regulación y crisis del capitalismo. México: Siglo XXI, 1986. p.89-128.

ANDRADE, Candido Teobaldo de Souza. Relações públicas na administração pública. Revista de Organização e Produtividade. São Paulo, v.33, n.393-394, p.17-18, set./out. 1964.

ANDRADE, Candido Teobaldo de Souza. O público: sua amplitude e duração. Revista de Organização e Produtividade. São Paulo, v.34, n.397-398, p.24-26, jan./fev. 1965.

ANDRADE, Candido Teobaldo de Souza. Aspectos gerais de relações públicas. Revista de Organização e Produtividade. São Paulo, v.34, n.399-400, p.9-10, mar./abr. 1965.

ANDRADE, Candido Teobaldo de Souza. Relações públicas com os concorrentes. Revista de Organização e Produtividade. São Paulo, v.34, n.401-402, p.14-15, maio/jun. 1965.

ANDRADE, Candido Teobaldo de Souza. Relações com o público misto. Revista de Organização e Produtividade. São Paulo, v.34, n.405-406, p.10-11, set./out. 1965.

ANDRADE, Candido Teobaldo de Souza. VI Conferência Interamericana de Relações Públicas em Montevideu. Revista de Organização e Produtividade. São Paulo, v.34, n.407-408, p.28-29, nov./dez. 1965.

ANDRADE, Candido Teobaldo de Souza. Ensino de relações públicas ao nível universitário aprovado na conferência internacional de RP. Revista de Organização e Produtividade. São Paulo, v.35, n.419-420, p.28-30, nov./dez. 1966. 
ANTONACCI, M. Antonieta M. A vitória da razão(?): O IDORT e a Sociedade Paulista. São Paulo: Marco Zero, 1993.

ANTUNES, Ricardo. Os sentidos do trabalho: ensaio sobre a afirmação e a negação do trabalho. São Paulo: Boitempo Editorial, 1999.

ANTUNES, Ricardo. O caracol e sua concha: ensaios sobre a nova morfologia do trabalho. São Paulo: Boitempo Editorial, 2005.

ARAÚJO, Carlos Alberto. A pesquisa norte-americana. In: HOHLFELDT, Antonio; MARTINO, Luiz C.; FRANÇA, Vera Veiga (Orgs.). Teorias da Comunicação: conceitos, escolas e tendências. 7. ed. Petrópolis, RJ: Vozes, 2008. p.119-130.

ARAÚJO, Manoel dos Reis. Relações públicas e organização. Revista de Organização e Produtividade, São Paulo, v.34, n.401-402, p.3, maio/jun. 1965.

ASSOCIAÇÃO BRASILEIRA DE RELAÇÕES PÚBLICAS. Revista de Organização e Produtividade. São Paulo, v.23, 275-276, p.29-30, 1954-1955.

ATIVIDADES DA ASSOCIAÇÃO BRASILEIRA DE RELAÇÕES PÚBLICAS. Revista de Organização e Produtividade. São Paulo, v.25, 280-288, p.34, 1956.

AZAMBUJA, Germano Augusto. Entre o branco e o negro: as opções do funcionalismo público na comunicação organizacional entre as imposições sistêmicas e as negociações do mundo da vida. 2003. 2v. Tese (Doutorado em Ciências da Comunicação) - Escola de Comunicações e Artes, Universidade de São Paulo, São Paulo, 2003.

BALDISSERA, Rudimar. Comunicação organizacional: o treinamento de recursos humanos como rito de passagem. São Leopoldo: Editora da Unisinos, 2000.

BALDISSERA, Rudimar. Imagem-conceito: anterior à comunicação, um lugar de significação. 2004. 295 f. Tese (Doutorado em Comunicação Social) - Pontifícia Universidade Católica do Rio Grande do Sul, Porto Alegre, 2004.

BARBIERI, Hugo. Idort e relações públicas. Revista de Organização e Produtividade. São Paulo, v.25, n.291-292, p.78-80, 1956. 
BOMFIM, Annibal. Relações Humanas e produtividade. Revista de Organização e Produtividade. São Paulo, v.23, n.265, p.34-38, 1954-1955a.

BOMFIM, Annibal. Os serviços de relações públicas. Revista de Organização e Produtividade. São Paulo, v.23, n.127-128, 1954-1955b.

BRAVERMAN, Harry. Trabalho e capital monopolista. Rio de Janeiro: Zahar, 1987.

BUENO, Wilson da Costa. Comunicação empresarial: teoria e pesquisa. Barueri: Editora Manole, 2003.

BUENO, Wilson da Costa. Comunicação empresarial no Brasil: uma leitura crítica. São Paulo: Mojoara Editorial, 2007.

BURRELL, Gibson. Ciência normal, paradigmas, metáforas, discursos e genealogia da análise. In: CLEGG, Stewart R. et al. Handbook de estudos organizacionais. São Paulo: Atlas, 1998. v.1, p. $439-465$.

CASALI, Adriana Machado. Comunicação organizacional: uma ciência híbrida (James Taylor). Revista de Estudos de Jornalismo e Relaçôes Públicas. revista da Faculdade de Jornalismo e Relações Públicas da Universidade Metodista de São Paulo, São Bernardo do Campo, ano 3, n.6, p.9-15, dez. 2005a.

CASALI, Adriana Machado. Comunicação organizacional: uma introdução à perspectiva da "Escola de Montreal". Revista de Estudos de Jornalismo e Relações Públicas. revista da Faculdade de Jornalismo e Relações Públicas da Universidade Metodista de São Paulo, São Bernardo do Campo, ano 3, n.6, p.28-40, dez. 2005b.

CASALI, Adriana Machado. Comunicação organizacional em fusões e aquisições internacionais. 2006. 203 f. Tese (Doutorado em Engenharia da Produção e Sistemas) Universidade Federal de Santa Catarina, Florianópolis, 2006.

CHAVES, Sylla Magalhães. Aspecto de relações públicas. Serviço de Documentação do DASP, 1963. Separata da: Revista do Serviço Público, Serviço de Documentação do Departamento Administrativo do Serviço Público (DASP), abr./jun. 1961; jan./mar. 1962; out./dez. 1962.

CLUBES E JORNAIS DE EMPRESAS. Revista de Organização e Produtividade. São Paulo, v.25, n.289-290, p.34, 1956. 
COELI, Jaime Pacini. Programa de relações públicas para o serviço público paulista. São Paulo: Departamento Estadual de Administração (DEA), 1962.

CONGRESSO DE RELAÇÕES PÚBLICAS DEMONSTRA CATEGORIA PROFISSIONAL. Revista de Organização e Produtividade. São Paulo, v.36, n.429-430, p.31-32, nov./dez. 1967.

CORIAT, Benjamin. Pensar pelo avesso: o modelo japonês de trabalho e organização. Rio de Janeiro: Editora da UFRJ / Revan, 1994.

CURVELlO, João José Azevedo. Autopoiese, sistema e identidade. a comunicação organizacional e a construção de sentido em um ambiente de flexibilização nas relações de trabalho. 2001. 162 f. Tese (Doutorado em Ciências da Comunicação) - Escola de Comunicações e Artes, Universidade de São Paulo, São Paulo, 2001.

CURVELlO, João José Azevedo. Comunicação interna e cultura organizacional. São Paulo: Scortecci, 2002.

DEJOURS, Christophe. A loucura do trabalho: estudo de psicopatologia do trabalho. São Paulo: Cortez, 1987.

DEJOURS, Christophe. A banalização da injustiça social. 7. ed. Rio de Janeiro: Editora FGV, 2007.

DURAND, Pierre Jean. A refundação do trabalho no fluxo tensionado. Tradução de tradução de Leonardo Gomes Mello e Silva. Tempo Social: Revista de Sociologia da USP. v.15, n.1, p.139-158, abr. 2003.

FÍGARO PAULINO, Roseli A. Estudo de recepção: o mundo do trabalho como mediação da comunicação. 1999. 284 f. Tese (Doutorado em Ciências da Comunicação) - Escola de Comunicações e Artes, Universidade de São Paulo, São Paulo, 1999.

FÍGARO PAULINO, Roseli A. Comunicação e trabalho: estudo de recepção: o mundo do trabalho como mediação da comunicação. São Paulo: Anita / Fapesp, 2001a.

FÍGARO, Roseli. Comunicação, mundo do trabalho e subjetividade. In: CONGRESSO BRASILEIRO DE CIÊNCIAS DA COMUNICAÇÃO, 24, 2001, Campo Grande. Anais... Campo Grande, 2001b. 1 CD-ROM. 
FÍGARO, Roseli. Comunicação e trabalho: contribuição epistemológica/ergológica às pesquisas de comunicação. In: CONGRESSO BRASILEIRO DE CIÊNCIAS DA COMUNICAÇÃO, 30, 2007, Santos. Anais... Santos: Unisanta / Unisantos / Unimonte, 2007. 1 CD-ROM

FÍGARO, Roseli. Relações de comunicação no mundo do trabalho. São Paulo: Annablume, 2008a.

FÍGARO, Roseli. Comunicação e trabalho: binômio teórico produtivo para as pesquisas de recepção. In: ENCONTRO DA COMPÓS, 17, 2008, São Paulo. Anais eletrônicos... São Paulo: UNIP, 2008b. Disponível em: <www.compos.org.br/data/biblioteca_407.pdf >. Acesso em jan 2007.

FLEURY, Maria Tereza Leme; FLEURY, Afonso. Construindo o conceito de competência. Revista de Administração Contemporânea: edição especial, Rio de Janeiro, p.183-196, 2001.

FRANÇA, Vera Veiga. O objeto da comunicação / A comunicação como objeto. In: HOHLFELDT, Antonio; MARTINO, Luiz C.; FRANÇA, Vera Veiga (Orgs.). Teorias da Comunicação: conceitos, escolas e tendências. 7. ed. Petrópolis: Vozes, 2007. p.39-60.

GORZ, André. Adeus ao proletariado. Rio de Janeiro: Forense Universitária, 1982.

JAMES, Louiz. Chefia e relações humanas. Revista de Organização e Produtividade. São Paulo, v.25, n.280-288, p.22-24, 1956.

KEHL, Renato. O problema das relações humanas. Revista de Organização e Produtividade. São Paulo, v.25, n.295-296, p.42, 1956.

KUNSCH, Margarida Maria Krohling. Relações Públicas e modernidade: novos paradigmas na comunicação organizacional. 3. ed. São Paulo: Summus Editorial, 1997.

KUNSCH, Margarida Maria Krohling. A pesquisa acadêmico-científica no campo das relações públicas e da comunicação organizacional no Brasil. In: LOPES, Maria Immacolata Vassalo de (Org.). Vinte anos de ciências da comunicação no Brasil: avaliação de Perspectivas. Santos: Universidade Santa Cecília / Intercom, 1999. p.137-159. 
KUNSCH, Margarida Maria Krohling. Tendências da produção científica em relações públicas e comunicação organizacional no Brasil. Comunicação \& Sociedade, São Bernardo do Campo, ano 24 , n.39; 2003a. p.93-125.

KUNSCH, Margarida Maria Krohling. Planejamento de relações públicas na comunicação integrada. 4. ed. revista, ampliada e atualizada. São Paulo: Summus Editorial, 2003b.

KUNSCH, Margarida Maria Krohling. As interfaces dos campos acadêmicos de Comunicação Organizacional e Relações Públicas no Brasil. In: LOPES, Maria Immacolata Vassalo de et al. (Orgs.). Pensamento Comunicacional Brasileiro. São Paulo: Intercom, 2005. p.44-60.

KUNSCH, Margarida Maria Krohling. Comunicação organizacional: conceitos e dimensões dos estudos e das práticas. In: MARCHIORI, Marlene (Org.). Faces da cultura e da comunicação organizacional. São Caetano do Sul: Difusão Editora, 2006. p.167-190.

LIMA, Eurenice. Toyota: a inspiração japonesa e os caminhos do consentimento. In: ANTUNES, Ricardo (Org.). Riqueza e Miséria do Trabalho no Brasil. São Paulo: Boitempo, 2006. p.115-145.

LINHART, Danièle. As empresas e o engajamento total dos empregados [Entrevista]. Revista do Instituto Humanitas Unisinos, São Leopoldo. 24 abr. 2006. Disponível em: $<$ http://www.unisinos.br/ihuonline/index.php?option=com_edicoes\&Itemid=18 $>$. Acessado em: 27 dez. 2006.

LINHART, Danièle. A desmedida do capital. São Paulo: Boitempo, 2007.

LUSO JUNIOR, José de Araujo. Os serviços públicos e a opinião pública. Revista de Organização e Produtividade. São Paulo, v.23, n.266-267, p.79-81, 1954-1955.

MARCHIORI, Marlene. Cultura e comunicação organizacional: uma perspectiva abrangente e inovadora na proposta de inter-relacionamento organizacional. In: (Org.). Faces da cultura e da comunicação organizacional. São Caetano do Sul: Difusão Editora, 2006a. p.7794.

MARCHIORI, Marlene. Comunicação interna: um fator estratégico no sucesso dos negócios. In: __ (Org.). Faces da cultura e da comunicação organizacional. São Caetano do Sul: Difusão Editora, 2006b. p.205-222. 
MARCHIORI, Marlene. Cultura e comunicação organizacional. São Caetano do Sul: Difusão Editora, 2006c.

MARCHIORI, Marlene. Comunicação interna: um olhar mais amplo no contexto das organizações. In: CONGRESO LATINOAMERICANO DE INVESTIGACIÓN DE LA COMUNICACIÓN, 9, 2008, México. Anais eletrônicos... México: Tecnológico de Monterrey / Asociación Latinoamericana de Investigadores de la Comunicación, 2008a. Disponível em: $<$ http://www.alaic.net/alaic30/ponencias/cartas/com_org_yRP/ponencias/GT2_1marchiori.pd f.>. Acesso em: dez. 2008.

MARCHIORI, Marlene. O desafio da comunicação interna nas organizações. CONGRESSO BRASILEIRO DE CIÊNCIAS DA COMUNICAÇÃO, 31, 2008, Natal. Anais... Natal: Universidade Federal do Rio Grande do Norte, 2008b. Disponível em: $<$ http://www.intercom.org.br/papers/nacionais/2008/resumos/R3-0596-2.pdf. $>$. Acesso em: dez. 2008.

MARCHIORI, Marlene. Comunicação organizacional e perspectivas metateóricas: interfaces e possibilidades de diálogo no contexto das organizações. In: OLIVEIRA, Ivone de Lourdes; SOARES, Ana Thereza Nogueira (orgs). Interfaces e tendências da comunicação no contexto das organizações. São Caetano do Sul: Difusão Editora, 2008c. p.179- 200.

MARTÍN-BARBERO, Jesus. América Latina e os anos recentes: o estudo da recepção em comunicação social. In: SOUZA, Mauro Wilton de. Sujeito, o lado oculto do receptor. São Paulo: Editora Brasiliense, 1995. p.39-67.

MARTÍN-BARBERO, Jesus. Dos meios às mediações comunicação, cultura e hegemonia. Rio de Janeiro: Editora UFRJ, 2003.

MARTÍN-BARBERO, Jesús. Ofício de cartógrafo: travessias latino-americanas da comunicação na cultura. São Paulo, Loyola, 2004.

MARTÍN-BARBERO, Jesús. Tecnicidades, identidades, alteridades: mudanças e opacidades da comunicação no novo século. In: MORAES, Dênis de. Sociedade midiatizada. Rio de Janeiro: Mauad, 2006. p.51-79.

MARTINO, Luiz C. (Org.). Teorias da comunicação: muitas ou poucas?. Cotia: Ateliê Editorial, 2007. 
MARX, Karl. Trabalho produtivo e trabalho improdutivo. In: ANTUNES, Ricardo (Org.). $A$ dialética do trabalho: escritos de Marx e Engels. São Paulo: Expressão Popular, 2004. p.155171.

MELLO E SILVA, Leonardo. Trabalho em grupo e sociabilidade privada. São Paulo: Editora 34, 2004.

MELLO E SILVA, Leonardo. A individualização do trabalhador [Entrevista]. Revista do Instituto Humanitas Unisinos, São Leopoldo. 24 abr. 2006. Disponível em: $<$ http://www.unisinos.br/ihuonline/index.php?option=com_edicoes\&Itemid=18 $>$. Acessado em: 27 dez. 2006.

MESTIERI, Carlos Eduardo. Relações Públicas: a arte de harmonizar expectativas. São Paulo: Aberje Editorial, 2004.

NASSAR, Paulo. Comunicação e organizações brasileiras nos anos 1970: estudo de caso sobre o papel da ABERJE, no período 1967-1983, para a definição de um primeiro paradigma para a comunicação organizacional brasileira. 2001. 113 f. Dissertação (Mestrado em Ciências da Comunicação) - Escola de Comunicações e Artes, Universidade de São Paulo, São Paulo, 2001.

NASSAR, Paulo. (Org.). Comunicação interna: a força das empresas. v.1. São Paulo: ABERJE Editorial, 2003.

NASSAR, Paulo. (Org.). Memória de empresa: história e comunicação de mãos dadas, a construir o futuro das organizações. São Paulo: ABERJE Editorial, 2004.

NASSAR, Paulo. (Org.). Comunicação empresarial: estratégia de organizações vencedoras. v.1. São Paulo: ABERJE Editorial, 2005a.

NASSAR, Paulo. (Org.). Comunicação interna: a força das empresas. v.2. São Paulo: ABERJE Editorial, 2005b.

NASSAR, Paulo. (Org.). Comunicação Empresarial: estratégia de organizações vencedoras. v.2. São Paulo: ABERJE Editorial, 2006a.

NASSAR, Paulo. (Org.). Comunicação interna: a força das empresas. v.3. São Paulo: ABERJE Editorial, 2006b. 
NASSAR, Paulo. A comunicação como valor estratégico. In: MARCHIORI, Marlene (Org.). Faces da cultura e da comunicação organizacional. São Caetano do Sul: Difusão Editora, 2006c. p.239-248.

NASSAR, Paulo. Aberje 40 anos: uma história da Comunicação Organizacional brasileira. Organicom: Revista Brasileira de Comunicação Organizacional e Relações Públicas, São Paulo, ano 4, n.7, p.30-43, 2007.

NASSAR, Paulo. Conceitos e processos de comunicação organizacional. In: KUNSCH, Margarida Maria Krohling (Org.). Gestão Estratégica em Comunicação Organizacional e Relações Públicas. São Caetano do Sul: Difusão Editora, 2008a. p.61-75.

NASSAR, Paulo. (Org.). Comunicação interna: a força das empresas. v.4. São Paulo: ABERJE Editorial, 2008b.

NASSAR, Paulo. Tudo é comunicação. São Paulo: Lazuli Editora, 2006d.

NASSAR, Paulo; FIGUEIREDO, Rubens. O que é comunicação empresarial. São Paulo: Brasiliense, 1995.

NASSAR, Paulo; RIBEIRO, Janine; GUTILLA, Rodolfo Witzig (orgs). A comunicação organizacional frente ao seu tempo: missão, visão e valores ABERJE. São Paulo: ABERJE Editorial, 2007.

NOÇÕES ELEMENTARES QUE DEVEM SER SEMPRE LEMBRADAS AOS QUE TÊM RESPONSABILIDADES DE DIREÇÃO E COMANDO. Revista de Organização e Produtividade. São Paulo, v.25, n.293-294, p.43, 1956.

OFFE, Claus. Capitalismo desorganizado. São Paulo: Brasiliense, 1984.

OLIVEIRA, Eurenice [Eurenice Lima]. Toyotismo no Brasil: desencantamento da fábrica, envolvimento e resistência. São Paulo: Expressão Popular, 2004.

OLIVEIRA, Ivone de Lourdes; DE PAULA, Maria Aparecida. O que é comunicação estratégica nas organizações?. São Paulo: Paulus, 2007. 
OLIVEIRA, Ivone de Lourdes; SOARES, Ana Thereza Nogueira (Orgs). Interfaces e tendências da comunicação no contexto das organizações. São Caetano do Sul: Difusão Editora, 2008.

ORGANICOM: Revista Brasileira de Comunicação Organizacional e Relações Públicas. São Paulo: Curso de Pós-Graduação de Gestão Estratégica em Comunicação Organizacional e Relações Públicas, ano 2, n.2, 2005. Dossiê Identidade, marca e gestão da reputação corporativa.

PEDROMÔNICO, Hermínio. RP: função administrativa de coordenação. Revista de Organização e Produtividade. São Paulo, v.34, n.403-404, p.21-22, jul./ago. 1965.

PERUZZO, Cicilia Krohling. Relações públicas no modo de produção capitalista. 2. ed. São Paulo: Summus Editorial, 1986.

PUTNAM, Linda L.; PACANOWSKY, Michael E. Communication and organizations: an interpretative approach. Newbury Park, California: Sage Publications, 1983.

PUTNAM, Linda L.; PHILLIPS, Nelson; CHAPMAN, Pamela. Metáforas da comunicação e da organização. In: CLEGG, Stewart r. et al. (Orgs.) Handbook de estudos organizacionais. São Paulo: Atlas, 2004. v.3, p. 77-125.

RÜDIGER, Francisco. Introdução à Teoria da Comunicação: problemas correntes e autores. São Paulo: Edicon, 1998.

SCROFERNEKER, Cleusa M. A. Trajetórias teórico-conceituais da comunicação organizacional. Revista FAMECOS, Porto Alegre, v.31, n.31, p.47-53, dez. 2006.

TAYLOR, Frederick W. Princípios da administração científica. São Paulo: Atlas, 1978.

TAYLOR, James R. Rethinking the theory of organizational communication: how to read na organization. New Jersey: Ablex Publishing, 1993.

THOMPSON, JOHN B. Ideologia e cultura: teoria social crítica na era dos meios de comunicação de massa. Petrópolis: Vozes, 1995.

TORQUATO, Gaudêncio. Jornalismo empresarial: teoria e prática. São Paulo: Summus Editorial, 1984. 
TORQUATO, Gaudêncio. Comunicação empresarial / comunicação institucional: conceitos, estratégias, sistemas, estrutura, planejamento e técnicas. 2. ed. São Paulo: Summus Editorial, 1986.

TORQUATO, Gaudêncio. Tratado de comunicação organizacional e política. São Paulo: Pioneira Thomson Learning, 2004.

VIDIGAL, Luís Roberto. Relações Humanas no trabalho. Revista de Organização e Produtividade. São Paulo, v.25, n.280-288, p.31-32, 1956.

WILLIAMS, Raymond. Cultura. 2. ed. Rio de Janeiro: Paz e Terra, 1992.

WOLTON, Dominique. É preciso salvar a comunicação. São Paulo: Paulus, 2006.

ZARIFIAN, Philippe. Trabalho e comunicação nas indústrias automatizadas. Tempo Social: Revista de Sociologia da USP. v.3, n.1-2, p.119-130, 1991.

ZARIFIAN, Philippe. Objetivo competência: por uma nova lógica. São Paulo: Atlas, 2001.

ZARIFIAN, Philippe. A gestão do conhecimento fornece bases para compreender fenômenos técnicos ou sociais [Entrevista]. Revista do Instituto Humanitas Unisinos, São Leopoldo. 24 abr. 2006. Disponível em: <http://www.unisinos.br/ihuonline /index.php?option=com_edicoes\&Itemid=18>. Acessado em: 27 dez. 2006. 


\section{Apêndice}

\section{Quadro descritivo dos textos analisados do periódico Revista Brasileira de Comunicação Empresarial [Comunicação Empresarial $]^{54}$, editado pela Aberje}

\section{Legendas:}

*: quando nem colaborador, nem jornalista assinam a matéria. Em geral, sem qualquer assinatura.

\#: refere-se ao à edição com mudança de nome para apenas Comunicação Empresarial. Estará subseqüente ao número.

**: refere-se à matéria de capa. Estará subseqüente ao título

$\mathrm{V}$ : categoria temática da matéria no eixo "valorização da pessoa".

A: categoria temática da matéria no eixo "acessibilidade à informação".

R: categoria temática da matéria no eixo "racionalidade da empresa".

I: categoria temática da matéria no eixo "individualização do trabalhador".

\begin{tabular}{|c|c|c|c|c|c|}
\hline $\begin{array}{c}\text { Ano de } \\
\text { publicação }\end{array}$ & Autoria & Título & $\begin{array}{c}\text { Ano / } \\
\text { Número }\end{array}$ & $\begin{array}{c}\text { Página } \\
\text { inicial - } \\
\text { final }\end{array}$ & $\begin{array}{l}\text { Categoria } \\
\text { temática }\end{array}$ \\
\hline \multirow{5}{*}{1991} & * & Comunicação interna, uma força ${ }^{* *}$ & $1 / 2$ & $10-16$ & $\mathrm{~V} ; \mathrm{A} ; \mathrm{R}$ \\
\hline & * & Adeus à política do avestruz & $1 / 2$ & $18-20$ & A \\
\hline & * & $\begin{array}{l}\text { O videogame apresenta a firma ao } \\
\text { funcionário }\end{array}$ & $1 / 2$ & 27 & A \\
\hline & * & A linguagem comum & $1 / 3$ & 11 & A \\
\hline & * & Simples, direto e grátis & $1 / 4$ & 44 & A \\
\hline \multirow{3}{*}{1992} & * & A esperança mora ao lado & $2 / 6$ & $12-13$ & $\mathrm{~V}$ \\
\hline & * & Comportamento exemplar & $2 / 6$ & 14 & V; R \\
\hline & Miriam Sanger & No coração da mata ${ }^{* \star}$ & $2 / 7$ & $10-14$ & V \\
\hline \multirow[b]{3}{*}{1993} & Carlos Moreira & Informação na ponta da linha & $3 / 8$ & $26-28$ & $\mathrm{~A} ; \mathrm{R}$ \\
\hline & $\begin{array}{c}\text { Célia } \\
\text { Cambraia }\end{array}$ & A marca da qualidade & $3 / 8$ & 29 & A \\
\hline & $\begin{array}{c}\text { Saul Faingans } \\
\text { Bekin }\end{array}$ & A eficiência começa em casa & $3 / 9$ & $20-20$ & $\mathrm{R}$ \\
\hline
\end{tabular}

${ }^{54}$ O periódico editado pela ABERJE denominou-se Revista Brasileira de Comunicação Empresarial até o referido ano 16, número 58, no primeiro trimestre de 2006. Já a partir da edição número 59, ela começou a ser denominada apenas Comunicação Empresarial. É importante salientar, possivelmente por um erro editorial, que as revistas de 1998, então ano 8, circularam como ano 7 (a mesma referência às publicações de 1997). Desde então, e até o correto ano 10, os periódicos passaram a seguir a numeração de ano sem desfazer o erro. Por exemplo, o ano de 1999, sendo corretamente o ano 9, passou a ser o ano 8 e assim por diante, até o exemplar do primeiro trimestre do ano 2000, quando se corrigiu o erro. No quadro acima, optamos por respeitar a numeração de ano estipulada pela ABERJE. Apenas acrescentou-se a suposta numeração correta entre parênteses ao lado do ano adotado no periódico, quando assim foi detectado o erro editorial. Para finalizar, é importante apontar que as revistas de 2007 constituem parte deste levantamento, embora nenhum texto das edições deste referido ano tenha sido selecionado para a análise; assim se explica o fato de nenhuma revista de 2007 constar no quadro deste apêndice. 


\begin{tabular}{|c|c|c|c|c|c|}
\hline $\begin{array}{l}\text { Ano de } \\
\text { publicação }\end{array}$ & Autoria & Título & $\begin{array}{l}\text { Anol } \\
\text { Número }\end{array}$ & $\begin{array}{c}\text { Página } \\
\text { inicial - } \\
\text { final }\end{array}$ & $\begin{array}{l}\text { Categoria } \\
\text { temática }\end{array}$ \\
\hline \multirow{6}{*}{1994} & * & O desafio de ser único & $4 / 11$ & $14-17$ & $\mathrm{~A} ; \mathrm{R}$ \\
\hline & * & O segredo do negócio ${ }^{\star *}$ & $4 / 11$ & $20-23$ & $\mathrm{R}$ \\
\hline & $\begin{array}{l}\text { Sidney } \\
\text { Gusman }\end{array}$ & Parceria indispensável $^{\star \star}$ & $4 / 12$ & 4-8 & A; R; I \\
\hline & * & Perfil revisto e ampliado & $4 / 13$ & $4-7$ & $\mathrm{R}$ \\
\hline & $\begin{array}{c}\text { Margarida M. } \\
\text { Krohling } \\
\text { Kunsch }\end{array}$ & Comunicação e cidadania & $4 / 13$ & $10-12$ & $\mathrm{~V} ; \mathrm{R}$ \\
\hline & $*$ & O canal das agências & $4 / 13$ & 25 & A \\
\hline \multirow{3}{*}{1995} & * & O gigante está acordado ${ }^{* *}$ & $5 / 14$ & $4-9$ & V; A; R \\
\hline & * & A palavra do presidente ${ }^{\star *}$ & $5 / 14$ & 10 & $\mathrm{R}$ \\
\hline & * & Campeões de audiência & $5 / 15$ & $19-21$ & A \\
\hline \multirow{10}{*}{1996} & Luciana Uchoa & Informação e mercado globalizado ${ }^{* *}$ & $6 / 18$ & $4-9$ & R; I \\
\hline & * & $\begin{array}{l}\text { "Sem comunicação, uma empresa não } \\
\text { existe" }\end{array}$ & $6 / 18$ & $10-12$ & $\mathrm{~V} ; \mathrm{R}$ \\
\hline & $\begin{array}{c}\text { José } \\
\text { Guilherme de } \\
\text { Oliveira }\end{array}$ & Por uma comunicação de qualidade & $6 / 18$ & $18-20$ & V; R; I \\
\hline & $\begin{array}{c}\text { Rinaldo } \\
\text { Campos } \\
\text { Soares } \\
\end{array}$ & Novas bases, novas relações & $6 / 19$ & 38 & $\mathrm{R}$ \\
\hline & $\begin{array}{c}\text { Maria } \\
\text { Aparecida de } \\
\text { Paula; Maria } \\
\text { Cristina Bahia } \\
\end{array}$ & A festa acabou & $6 / 20$ & $44-46$ & $\mathrm{~A} ; \mathrm{R}$ \\
\hline & $\begin{array}{l}\text { José Cerqueira } \\
\text { Filho }\end{array}$ & Comunicação não é analgésico & $6 / 21$ & $22-24$ & A; R; I \\
\hline & $\begin{array}{c}\text { Humberto } \\
\text { Manera Filho }\end{array}$ & Cortina de fumaça & $6 / 21$ & $32-36$ & $\mathrm{~V}$ \\
\hline & $\begin{array}{c}\text { Sidney } \\
\text { Gusman } \\
\end{array}$ & Espaço abertos & $6 / 21$ & $38-39$ & $\mathrm{~A} ; \mathrm{R}$ \\
\hline & $\begin{array}{l}\text { Antônio } \\
\text { Roberto de } \\
\text { Azevedo } \\
\text { Müller }\end{array}$ & A prova da qualidade & $6 / 21$ & $12-13$ & $\mathrm{R}$ \\
\hline & Alceu Nader & A outra revolução & $6 / 21$ & $48-52$ & A \\
\hline \multirow{8}{*}{1997} & Paulo Nassar & As tecnologias em discussão & $7 / 22$ & $16-$ & A \\
\hline & * & Nos cafundós de Minas & $7 / 23$ & $28-32$ & $\mathrm{R}$ \\
\hline & * & Em busca do tempo perdido & $7 / 24$ & $15-18$ & $\mathrm{R}$ \\
\hline & $\begin{array}{c}\text { Carlos } \\
\text { Eduardo } \\
\text { Moreira } \\
\text { Ferreira } \\
\end{array}$ & Educação para o futuro & $7 / 24$ & 19 & $\mathrm{R}$ \\
\hline & * & Visão global, comunicação local & $7 / 24$ & $23-27$ & A; R \\
\hline & * & A lição de casa & $7 / 24$ & $48-52$ & V; A; R \\
\hline & Walter Nori & Uma tarefa de todos & $7 / 24$ & 54 & $\mathrm{~V} ; \mathrm{R}$ \\
\hline & Nara Damante & Melhoria contínua & $7 / 25$ & $64-68$ & $\mathrm{R}$ \\
\hline
\end{tabular}




\begin{tabular}{|c|c|c|c|c|c|}
\hline $\begin{array}{c}\text { Ano de } \\
\text { publicação }\end{array}$ & Autoria & Título & $\begin{array}{l}\text { Ano / } \\
\text { Número }\end{array}$ & $\begin{array}{c}\text { Página } \\
\text { inicial - } \\
\text { final }\end{array}$ & $\begin{array}{l}\text { Categoria } \\
\text { temática }\end{array}$ \\
\hline \multirow{8}{*}{1998} & $\begin{array}{c}\text { Luiz Fernando } \\
\text { Cirne Lima }\end{array}$ & Receita de excelência & $7(8) / 26$ & $33-36$ & A; R; I \\
\hline & Luiz Egypto & Em se plantando, tudo dá & $7(8) / 26$ & $20-24$ & $\mathrm{~A}$ \\
\hline & $\begin{array}{c}\text { Paulo Nassar; } \\
\text { Roberto } \\
\text { Carlos } \\
\text { Bernardes } \\
\end{array}$ & Ajuste de foco & $7(8) / 27$ & $28-31$ & $\mathrm{R}$ \\
\hline & Artur Roman & Em nome da clareza & $7(8) / 28$ & $24-26$ & A \\
\hline & $\star$ & Todos no mesmo barco & $7(8) / 28$ & $13-14$ & $\mathrm{R} ; \mathrm{I}$ \\
\hline & $\begin{array}{c}\text { Carlos } \\
\text { Roberto Hohi }\end{array}$ & O bom problema & $7(8) / 29$ & $26-27$ & $\mathrm{R} ; \mathrm{I}$ \\
\hline & $\begin{array}{l}\text { Firmin } \\
\text { António }\end{array}$ & Revolução permanente & $7(8) / 29$ & 42 & $\mathrm{R}$ \\
\hline & $\begin{array}{l}\text { Sérgio W. } \\
\text { Hillesheim }\end{array}$ & Em nome da marca & $7(8) / 29$ & $38-40$ & $\mathrm{R}$ \\
\hline \multirow{12}{*}{1999} & Artur Roman & A eficiência digital $^{\star \star}$ & $8(9) / 30$ & $4-7$ & A \\
\hline & Fabio França & Informação na parede & $8(9) / 30$ & $30-32$ & A \\
\hline & Teresa Goulart & O fator humano & $8(9) / 30$ & $18-21$ & $\mathrm{R}$ \\
\hline & Marco Piquini & $\begin{array}{l}\text { MundoFiat: informação como } \\
\text { produto }\end{array}$ & $8(9) / 31$ & $13-14$ & A \\
\hline & Nara Damante & De fone no ouvido & $8(9) / 31$ & $16-21$ & A; R \\
\hline & * & $\begin{array}{l}\text { Gestores diretos têm papel decisivo na } \\
\text { difusão da comunicação interna }\end{array}$ & $8(9) / 32$ & $8-10$ & $\mathrm{R}$ \\
\hline & Nara Damante & $\begin{array}{l}\text { Boa comunicação interna é vantagem } \\
\text { competitiva }^{* *}\end{array}$ & $8(9) / 32$ & $25-28$ & $\mathrm{~A} ; \mathrm{R}$ \\
\hline & Nara Damante & $\begin{array}{l}\text { Bom para os negócios, melhor para os } \\
\text { funcionários }\end{array}$ & $8(9) / 32$ & $32-34$ & $\mathrm{~V}$ \\
\hline & * & Envolvimento e motivação & $8(9) / 33$ & 29 & $\mathrm{R}$ \\
\hline & $\begin{array}{l}\text { Firmin } \\
\text { António }\end{array}$ & Comunicação como arma da estratégia & $8(9) / 33$ & $30-33$ & $\mathrm{R}$ \\
\hline & $\begin{array}{l}\text { José Carlos } \\
\text { Grubisich }\end{array}$ & $\begin{array}{l}\text { Planos mobilizadores e gestões } \\
\text { capacitadas }\end{array}$ & $8(9) / 33$ & $34-35$ & $\mathrm{R}$ \\
\hline & Teresa Goulart & $\begin{array}{l}\text { Comunicação em processos de } \\
\text { mudança }\end{array}$ & $8(9) / 33$ & 50 & A; R \\
\hline \multirow{6}{*}{2000} & $\begin{array}{l}\text { Fátima Penna } \\
\text { Franca }\end{array}$ & Rede à toda prova & $10 / 34$ & $32-33$ & A \\
\hline & Solange Fusco & E a comunicação interna com isso? & $10 / 35$ & 34 & $\mathrm{R}$ \\
\hline & Nara Damante & "Conhece-te a ti mesmo" $* *$ & $10 / 36$ & $12-18$ & $\mathrm{~V} ; \mathrm{A} ; \mathrm{R}$ \\
\hline & Nara Damante & Força intrínseca & $10 / 37$ & $9-15$ & $\mathrm{~A} ; \mathrm{R}$ \\
\hline & $\begin{array}{c}\text { Nara } \\
\text { Damante; } \\
\text { Paulo Nassar }\end{array}$ & Talentos juntos fazem a diferença ${ }^{* *}$ & $10 / 37$ & $20-22$ & $\mathrm{R}$ \\
\hline & $\begin{array}{c}\text { Nara } \\
\text { Damante; } \\
\text { Paulo Nassar }\end{array}$ & Comunicar para servir bem & $10 / 37$ & $23-27$ & $\mathrm{~V} ; \mathrm{R}$ \\
\hline
\end{tabular}




\begin{tabular}{|c|c|c|c|c|c|}
\hline $\begin{array}{l}\text { Ano de } \\
\text { publicação }\end{array}$ & Autoria & Título & $\begin{array}{c}\text { Anol } \\
\text { Número }\end{array}$ & $\begin{array}{c}\text { Página } \\
\text { inicial - } \\
\text { final }\end{array}$ & $\begin{array}{l}\text { Categoria } \\
\text { temática }\end{array}$ \\
\hline \multirow{3}{*}{2001} & Nara Damante & O exemplo vem de casa & $11 / 38$ & $21-23$ & $\mathrm{~V} ; \mathrm{A} ; \mathrm{R}$ \\
\hline & $\begin{array}{l}\text { Fernando } \\
\text { Tadeu Perez }\end{array}$ & Flexibilização das relações do trabalho & $11 / 38$ & $46-47$ & $\mathrm{R}$ \\
\hline & $\begin{array}{c}\text { Nara } \\
\text { Damante; } \\
\text { Paulo Nassar }\end{array}$ & A pressão leva à transparência & $11 / 40$ & $12-16$ & $\mathrm{R}$ \\
\hline \multirow{4}{*}{2002} & $\begin{array}{l}\text { Iêda Maria } \\
\text { Pozo }\end{array}$ & Ver-sentir-mudar & $12 / 44$ & $20-22$ & $\mathrm{I}$ \\
\hline & André Senador & Olhos nos olhos & $12 / 45$ & $20-21$ & A \\
\hline & $\begin{array}{c}\text { Nara } \\
\text { Damante; } \\
\text { Marcelo Lopes }\end{array}$ & Nada substitui o diálogo ${ }^{* \star}$ & $12 / 45$ & $24-31$ & $\mathrm{~A} ; \mathrm{R}$ \\
\hline & $\begin{array}{c}\text { Francisco de } \\
\text { Carvalho }\end{array}$ & De coadjuvante a ator principal & $12 / 45$ & 42 & $\mathrm{R}$ \\
\hline 2003 & Paulo Nassar & O Big Brother Comunicacional & $13 / 47$ & 38 & $\mathrm{R}$ \\
\hline \multirow{3}{*}{2004} & Elisa Prado & Sua excelência, o público externo & $14 / 50$ & 34 & $\mathrm{R}$ \\
\hline & Nara Damante & $\begin{array}{l}\text { Marca interna promove integração da } \\
\text { PT }\end{array}$ & $14 / 51$ & $28-31$ & $\mathrm{~A} ; \mathrm{R}$ \\
\hline & Ana Couto & $\begin{array}{l}\text { Como transformar colaboradores em } \\
\text { embaixadores da marca }\end{array}$ & $14 / 53$ & 20 & $\mathrm{R}$ \\
\hline \multirow{8}{*}{2005} & Nara Damante & $\begin{array}{l}\text { Perseguindo a eficiência na gestão da } \\
\text { comunicação interna }\end{array}$ & $15 / 55$ & $4-6$ & $\mathrm{R}$ \\
\hline & Nara Damante & O fomento da miscigenação & $15 / 55$ & $31-37$ & $\mathrm{R}$ \\
\hline & Mauro Lopes & Como entender a alma da organização & $15 / 55$ & $50-51$ & $\mathrm{~V} ; \mathrm{A}$ \\
\hline & $\begin{array}{l}\text { Gilmar Pinto } \\
\text { Caldeira }\end{array}$ & Em busca de uma causa & $15 / 55$ & 54 & $\mathrm{R}$ \\
\hline & Olga Curado & As várias faces do conflito & $15 / 56$ & 10 & $\mathrm{R}$ \\
\hline & Nara Damante & $\begin{array}{l}\text { Face a face, a melhor forma de } \\
\text { comunicar }\end{array}$ & $15 / 57$ & $4-7$ & $\mathrm{~A} ; \mathrm{R}$ \\
\hline & Nara Damante & $\begin{array}{l}\text { Oralidade é a essência da comunicação } \\
\text { interna eficiente }\end{array}$ & $15 / 57$ & $22-26$ & $\mathrm{~A} ; \mathrm{R}$ \\
\hline & Nara Damante & $\begin{array}{l}\text { Sem comunicação, não há } \\
\text { produtividade }\end{array}$ & $15 / 57$ & $28-31$ & $\mathrm{R}$ \\
\hline \multirow{9}{*}{2006} & Nara Damante & $\begin{array}{l}\text { Responsabilidade social dentro da } \\
\text { própria casa }\end{array}$ & $16 / 58$ & $6-12$ & $\mathrm{~A} ; \mathrm{R} ; \mathrm{I}$ \\
\hline & $\star$ & Sucesso de público & $16 / 59 \#$ & 10 & A \\
\hline & ${ }^{*}$ & A número um & $16 / 59 \#$ & 15 & $\mathrm{~A} ; \mathrm{R}$ \\
\hline & * & Pesquisar é preciso & $16 / 59 \#$ & 16 & $\mathrm{~A} ; \mathrm{R}$ \\
\hline & * & A hora e a vez do blog & $16 / 59 \#$ & $20-22$ & A \\
\hline & * & Ordem na casa & 16/59\# & $24-27$ & $\mathrm{~A} ; \mathrm{R}$ \\
\hline & * & Quem não se comunica & $16 / 59 \#$ & $28-29$ & $\mathrm{R}$ \\
\hline & $\begin{array}{l}\text { Luiz Márcio } \\
\text { Ribeiro Caldas } \\
\text { Júnior }\end{array}$ & Uma balzaquiana impecável & $16 / 59 \#$ & $36-38$ & $\mathrm{R}$ \\
\hline & $\begin{array}{l}\text { José Tolovi } \\
\text { Júnior }\end{array}$ & $\begin{array}{l}\text { Empresa excelente, comunicadores } \\
\text { líderes }\end{array}$ & $16 / 59 \#$ & 47 & $\mathrm{~V} ; \mathrm{R}$ \\
\hline
\end{tabular}




\begin{tabular}{|c|c|l|l|l|l|}
\hline $\begin{array}{c}\text { Ano de } \\
\text { publicação }\end{array}$ & Autoria & \multicolumn{1}{|c|}{ Título } & \multicolumn{1}{|c|}{$\begin{array}{c}\text { Ano / } \\
\text { Número }\end{array}$} & $\begin{array}{c}\text { Página } \\
\text { inicial - } \\
\text { final }\end{array}$ & $\begin{array}{l}\text { Categoria } \\
\text { temática }\end{array}$ \\
\hline \multirow{3}{*}{2006} & $*$ & $\begin{array}{l}\text { Uma nova comunicação para um novo } \\
\text { profissional }\end{array}$ & $16 / 59 \#$ & $52-53$ & $\mathrm{R}$ \\
\cline { 2 - 6 } & $*$ & Quanto vale o show & $16 / 60 \#$ & $26-29$ & $\mathrm{R}$ \\
\cline { 2 - 6 } & $*$ & Leitura dinâmica & $16 / 60 \#$ & $10-13$ & $\mathrm{~A} ; \mathrm{R}$ \\
\cline { 2 - 7 } & $*$ & Programa legal & $16 / 60 \#$ & $42-43$ & $\mathrm{~A}$ \\
\hline
\end{tabular}

